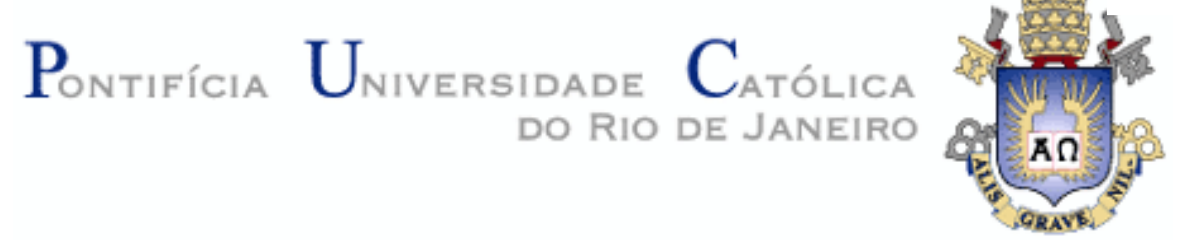

Carla da Luz Rodrigues Cardoso

\title{
Um olhar no passado: \\ Memórias de infância em Tanguá
}

Dissertação de Mestrado

Dissertação apresentada como requisito parcial para obtenção do grau de Mestre pelo Programa de Pósgraduação em Educação do Departamento de Educação do Centro de Teologia e Ciências Humanas da PUC-Rio

Orientadora: Prof ${ }^{\mathrm{a}}$. Sonia Kramer

Rio de Janeiro

Março de 2017 


\section{Um olhar no passado: Memórias de infância em Tanguá}

Dissertação apresentada como requisito parcial para obtenção do grau de Mestre pelo Programa de Pósgraduação em Educação do Departamento de Educação do Centro de Teologia e Ciências Humanas da PUC-Rio. Aprovada pela Comissão Examinadora abaixo assinada.

Prof ${ }^{a}$. Sonia Kramer

Orientadora

Departamento de Educação - PUC-Rio

Prof ${ }^{a}$. Isabel Alice 0 . Monteiro Lelis

Departamento de Educação - PUC-Rio

Prof ${ }^{\text {a }}$ Maria Tereza Goudard Tavares Universidade Estadual do Rio de Janeiro

Prof ${ }^{\text {a }}$ MonahWinograd Coordenadora Setorial do Centro de Teologia e Ciências Humanas

PUC-Rio

Rio de Janeiro, 31 de março de 2017. 
Todos os direitos reservados. É proibida a reprodução total ou parcial do trabalho sem autorização do autor, do orientador e da universidade.

\section{Carla da Luz Rodrigues Cardoso}

Possui graduação em Pedagogia pela Universidade Federal Fluminense(1997) e especialização em Educação Infantil pela Pontifícia Universidade Católica do Rio de Janeiro(2002). Tem experiência na área de Educação, com ênfase em Educação Infantil.

Ficha Catalográfica

Cardoso, Carla da Luz Rodrigues

Um olhar no passado: memórias de infância em Tanguá / Carla da Luz Rodrigues Cardoso; orientadora: Sonia Kramer. - 2017. $95 \mathrm{f} . ; 30 \mathrm{~cm}$

Dissertação (mestrado)-Pontifícia Universidade Católica do Rio de Janeiro, Departamento de Educação, 2017.

Inclui bibliografia

1. Educação - Teses. 2. Memória. 3. Histórias de vida. 4. Educação infantil. I. Kramer, Sonia. II. Pontifícia Universidade Católica do Rio de Janeiro. Departamento de Educação. III. Título. 
A Deus pela presença constante em minha vida, nas horas de alegria e tristeza e principalmente nos momentos de realização deste trabalho

A memória do meu pai José Carlos Rodrigues de quem ouvi muitas histórias sobre a cidade Tanguá

A todos os velhos moradores e as crianças da cidade de Tanguá. 


\section{Agradecimentos}

À minha orientadora Sonia Kramer pelo incentivo e colaboração nos momentos de realização deste trabalho.

À Alexandra Coelho Pena que muito me auxiliou na construção desta dissertação.

Às professoras Maria Tereza Goudard Tavares, Isabel Alice O. Monteiro Lelis e Cristina Laclette Porto que aceitaram participar da Comissão Examinadora

A todos os moradores entrevistados e profissionais que tornaram possível a § realização desta pesquisa.

Aos colegas da turma de mestrado do ano de 2015 pelas trocas realizadas e momentos de alegria.

Aos membros do grupo de pesquisa INFOC.

Às minhas irmãs pelo apoio e palavras de incentivo.

À minha mãe, pois através do seu amor e carinho pude chegar até aqui.

Ao meu esposo Márcio e a minha filha Maria Clara que com muito amor, carinho e alegria preenchem os meus dias 


\section{Resumo}

Cardoso, Carla da Luz Rodrigues; Kramer, Sonia. Um olhar no passado: Memórias de Infância em Tanguá. Rio de Janeiro, 2017. 95p. Dissertação de Mestrado- Departamento de Educação, Pontifícia Universidade Católica.

"Um olhar no passado: Memórias de Infância em Tanguá" tem como objetivo estudar as memórias de infância de velhos moradores da cidade. Esta dissertação busca a compreensão das seguintes questões: qual a relação entre a cidade de Tanguá e as crianças ao longo de sua história? Qual a importância da recuperação das memórias de vida dos velhos moradores da cidade para o trabalho com a educação infantil? Analisar as memórias de infância visa responder a estas questões para conhecer o lugar da infância na história da cidade. Visa também descortinar a visão de infância que ao longo da história foi construída pelos moradores e revelar "outras" histórias de Tanguá que não foram contadas na história oficial. Foram escolhidos como referências teóricas desta dissertação os autores: Walter Benjamim, Ecléa Bosi e William Corsaro. Estes produziram obras que, por caminhos diferentes, valorizaram a narração, o encontro e a relação entre os seres humanos como princípio que permite a compreensão crítica da realidade e da história e a participação na vida social.O primeiro capítulo traz os caminhos que levaram à estruturação desta pesquisa, os objetivos, a apresentação da cidade de Tanguá, a relação da pesquisadora com a cidade, bem como a revisão bibliográfica e a metodologia utilizada. No segundo capítulo estão as relevantes contribuições dos autores, citados acima, para esta dissertação, contribuições estas que foram fundamentais para pensar qual o lugar da infância na cidade de Tanguá ao longo da história e para a compreensão do valor da narrativa no trabalho com crianças na educação infantil. O terceiro capitulo apresenta um breve resumo sobre a história de cada entrevistado e sua relação com a cidade, o trabalho e a vida. O quarto capítulo traz as análises das histórias de vida e as categorias que emergiram das narrativas dos velhos moradores da cidade. No quinto capitulo as memórias são analisadas sob o prisma das possibilidades educativas que estas possuem para as futuras gerações da cidade, especificamente para o trabalho com a Educação Infantil. O capitulo final, parte do que é possível aprender com as histórias de vida e traz recomendações para a valorização da narrativa no trabalho com a educação infantil. 


\section{Palavras-chave}

Memória; Histórias de vida; Educação Infantil. 


\section{Abstract}

Cardoso, Carla da Luz Rodrigues; Kramer, Sonia (Advisor). A look in the past: Memories of Childhood in Tanguá. Rio de Janeiro,2017. 95p. Dissertação de Mestrado - Departamento de Educação, Pontifícia Universidade Católica do Rio de Janeiro.

"A look to the past: Childhood memories in Tanguá" aims to study childhood memories of old residents of the city. This dissertation seeks understanding of the following questions: what is the relationship between the city of Tanguá and children throughout your history? What is the importance of rescuing memories of life from the old residents of the city to work with early childhood education? Analyze the childhood memories aims to answer these questions to get to know the place of childhood in the history of the city. It also aims to uncover the vision of childhood that throughout history was built by locals and reveal "other" Tanguá stories that have not been told in the official story. Were chosen as theoretical references of this dissertation authors: Walter Benjamim, EcléaBosi and William Corsaro. These had produced works that, for different ways, had valued the narration, the meeting and the relation between the human beings as principle that allows to the critical understanding of the reality and history and the participation in the social life. The first chapter brings the ways that had led to the structuring of this research, the objectives, the presentation of the city of Tanguá, the relation of the researcher with the city, as well as the bibliographical revision and the used methodology. In the second chapter are the relevant contributions of the authors, mentioned above, for this dissertation, these contributions were fundamental to think what the place of childhood in the town of Tanguá throughout history and to understand the value of narrative in the work with children in early childhood education. The third chapter presents a brief summary about the history of each respondent and your relationship with the city, work and life. The fourth chapter brings the analysis of life stories and categories that emerged from the narratives from the old residents of the city. In the fifth chapter the memories are parsed on the prism of educational opportunities that they have for future generations of the city, specifically to work with early childhood education. The final chapter, starts from 
what you can learn of the stories of life and brings recommendations for enhancement of the narrative at work with early childhood education.

\section{Keywords}

Memory; Life stories; Childhood Education. 


\section{Sumário}

1. Introdução

2. Caminhos da pesquisa

2.1. A pesquisadora e a cidade: Eu e Tanguá

2.2.O encontro com os autores: concepções e levantamento bibliográfico

2.3. Histórias de vida: uma metodologia em busca das memórias de infância

3. O reencontro com os autores

3.1. História de Velhos - Eclea Bosi

3.2. A Narração - Walter Benjamim

3.3. A Infância - Willian Corsaro

4. Os velhos moradores de Tanguá: sua relação com a cidade, o trabalho e a vida

4.1. "Naquela época, criança queria crescer para fazer alguma coisa. Ser adulto para ter liberdade, isso que a gente queria" Senhora Alzira

4.2. "Olhava o chão de pertinho e perguntava: quando eu vou ver este chão de longe?" - Senhor Salim

4.3. "Agente não se esquece das coisas" - Senhora Maria 55 Augusta

4.4. "Mas a gente era feliz! Isso sem sombra de dúvida nenhuma” 56 - Senhor Rogério

4.5. "Ah! Era uma magia! Tudo bonito, muito colorido!" - Senhora 58 Elizete 
5.1. Memórias da Senhora Alzira e do Senhor Salim - "Desde 62 que eu me entendi por gente, eu ajudava a minha mãe"

5.2. Memórias da Senhora Maria Augusta e do Senhor Rogério 67

"Minha infância foi muito boa"

5.3. Memórias da Senhora Elizete e do Senhor Luís - "Liberdade! 72 Naquele tempo a gente tinha liberdade"

6. O encontro entre o passado, o presente e o futuro na 80 Educação Infantil

7. Considerações finais: o que podemos aprender quando 89 lançamos um olhar no passado

8. Referências bibliográficas 


\section{Introdução}

\footnotetext{
Os que vieram antes de mim, os que são bons e são velhos, aprenderam tudo que é minha vez de aprender.

Eles sabem o que eu não sei. Conhecem o que é bem e o que é mal e o que se deve fazer e o que não se deve.

Os que vieram antes de mim hão de me dar conselhos e hão de me citar exemplos.

$\mathrm{E}$, em vez de fazer como os rebeldes, que riem da sabedoria e desobedecem, hei de atender ao que me disserem e hei de refletir sobre isso.

E quando for minha vez de saber, hei de aconselhar também os que vierem depois de mim. (MEIRELES, 1977, p. 83)
}

Seguindo o caminho de Cecília Meireles, esta pesquisa parte ao encontro daqueles que vieram antes de nós - os velhos. Para receber conselhos e exemplos que ajudarão a aprender o que já sabem. Neste estudo, a aproximação com os velhos acontece com humildade, na intenção de atender ao que disserem e não fazer como os "rebeldes" que riem da sabedoria e chegando até mesmo a desconsiderá-la A partirdesde encontro a pesquisaconvida àreflexão sobre cada memória do passado e para, quem sabe assim, ao final, poder aconselhar os que vierem depois de cada um de nós.

Trilhando este caminho, a dissertação toma como objeto de estudo as histórias de vida de seis velhos moradores da cidade de Tanguá e tem como objetivo conhecer a relação que a cidade construiu ao longo de sua história com as crianças e com a infância. Com uma construção histórica realizada através do estudo das memórias de infância de velhos moradores, os objetivos específicos deste estudo são: conhecer as visões de infância que foram construídas ao longo da história da cidade; revelar o lugar da infância na vida da cidade; conhecer outras histórias da cidade de Tanguá que não foram contadas na história oficial.

Com uma visão crítica da história, analisa as memórias de infância dos velhos moradores de Tanguá para através delas, valorizar o trabalho com a narrativa na Educação Infantil. Foram escolhidos como referências teóricas desta dissertação os autores Walter Benjamim, Ecléa Bosi e William Corsaro, estes valorizaram a narração, o encontro e a relação entre os seres humanos como princípio que permite a compreensão crítica da realidade.

O material está organizado em cinco capítulos.

Em um movimento de apresentar os caminhos que levaram a estruturação da pesquisa, o primeiro capitulo traz os seguintes tópicos: os objetivos; a 
apresentação da cidade de Tanguá; a relação da pesquisadora com a cidade; a revisão bibliográfica e a apresentação da metodologia utilizada.

O capítulo 2 traz os autores que ajudaram a estruturar teoricamente o estudo das memórias de infância na cidade de Tanguá.Apresenta as relevantes contribuições de Eclea Bosi com enfoque nas histórias de velhos através de sua obra Memórias e Sociedade - Lembranças de Velhos; de Walter Benjamin e a Narração e de Willian Corsaro com a Sociologia da Infância.

No capítulo 3 os entrevistados são apresentados de acordo com a relação que construíram ao longo da vida com a cidade, com o trabalho e a com a vida.

No capítulo 4 as memórias de infância são analisadas através dos depoimentos que foram organizados por gerações e por gênero e, ao final,são apresentadas as categorias que emergiram das falas dos entrevistados

O capítulo 5 traz a reflexão sobre a importância de organizar uma educação entre gerações possibilitando o encontro entre presente, passado e futuro, para assim, viver plenamente a vida na cidade.

Esta dissertação é um convite para pensarmos: o que podemos aprender quando lançamos um olhar no passado? 


\section{Caminhos da pesquisa}

Assim como as flores dirigem sua corola para o sol, o passado, graças a um misterioso heliotropismo, anseia por dirigir-se para o sol que se levanta no céu da história. (BENJAMIN, 2012, p.243)

Este capítulo apresenta os objetivos da pesquisa, os autores de referência e a revisão da bibliografia que fundamentam o estudo, além da metodologia utilizada.

"Memórias de Infância em Tanguá" tem como objetivo estudar as memórias de infância de velhos moradores da cidade. O presente estudo busca a compreensão das seguintes questões: qual a relação entre a cidade de Tanguá e as crianças ao longo de sua história? Qual a importância da recuperação das memórias de vida dos velhos moradores da cidade para o trabalho com a Educação Infantil?

Analisar as memórias de infância visa responder a estas questões para conhecer o lugar da infância na história da cidade. Pretende também descortinar a visão de infância que ao longo da história foi construída pelos moradores;como também revelar "outras" histórias de Tanguá que não foram contadas na história oficial; e ainda contribuir para o resgate do valor da narrativa no trabalho com crianças na Educação Infantil.

Esta pesquisa acredita que a produção e o consumo de conceitos sobre a infância elaboradospela sociedade interferem diretamente no comportamento de crianças e dos adultos, e modelam formas de ser e agir de acordo com as expectativas criadas nos discursos que passam a circular entre as pessoas. Estas, por sua vez, correspondem aos interesses culturais, políticos e econômicos do contexto social mais amplo.

Partindo da premissa de que a produção de conhecimentos acerca da infância está intimamente ligada ao lugar social que a criança ocupa na relação com a sociedade, a questão desta pesquisa é:

- Conhecer a relação que a cidade de Tanguá construiu ao longo de sua história com as crianças e com a infância.

Esta construção histórica foi realizada através do estudo das memórias de infância dos velhos moradores da cidade de Tanguá, para atingir os seguintes objetivos: 
- Conhecer, através das narrativas, as visões de infância que foram construídas ao longo da história da cidade;

- Revelar o lugar da infância na vida da cidade, a partir das visões de infância construídas ao longo da história;

- Conhecer as "outras" histórias da cidade que não foram contadas na história oficial.

Esta reflexão acerca do lugar da infância na vida da cidade de Tanguá, realizada a partir das memórias dos velhos moradores da cidade, pretende contribuir para se pensar a experiência de ser criança em Tanguá e suas consequências para as ações com a infância.

Este estudo está inserido na pesquisa - Linguagem e rememoração: crianças famílias, professores/as e suas histórias, situada no âmbito do grupo de pesquisa Infância, Formação e Cultura (INFOC) da Pontifícia Universidade Católica do Rio de Janeiro (PUC- Rio) ${ }^{1}$, que têm como objetivo conhecer as histórias de vida de crianças, seus/suas professores/as e suas famílias, identificando e compreendendo as marcas presentes do cuidar e ser cuidado nas narrativas das pessoas que frequentam creches, pré-escolas e escolas. A pesquisa propõe-se aouvir esses sujeitos, suas histórias de vida, no entrecruzamento da experiência e rememoração do processo de educação, entendido como ensinar, cuidar e ser cuidado. (KRAMER, 2016, p. 2). A participação no Grupo de Pesquisa INFOC foi fundamental para definir e delinear o objeto deste estudo.

\subsection{A pesquisadora e a cidade: Eu e Tanguá}

Como em toda minha trajetória profissional, aqui neste trabalho se cruzam a mulher, a professora, a cidadã, a filha, a amiga e todos os outros papéis que desempenho. A minha chegada até aqui mistura vida e profissão. Parte do estudo proposto não é só fruto de uma fundamentação teórica específica; os conceitos e as indagações foram sendo construídos nas inúmeras interações ao longo dos anos de vida. Muito do que penso sobre infância vem das minhas reminiscências de criança: das inúmeras brincadeiras, do contato com minhas irmãs, da intimidade

\footnotetext{
${ }^{1}$ O INFOCé coordenado há 24 anos pelas professoras Sonia Kramer (PUC- Rio) e Maria Fernanda Rezende Nunes (UNIRIO) e faz parte do programa de Pós-Graduação do Departamento de Educação da PUC - Rio desde 1993.
} 
com o quintal da minha casa, da pré-escola que frequentei e das histórias que ouvia dos meus avós.

Moradora da cidade de Tanguá, localizada no interior do Estado do Rio de Janeiro, e estudante de escola pública, escolhi o magistério muito influenciada pelos meus pais que também eram professores. $\mathrm{O}$ interesse pela educação muito delineou os passos após o término do Curso Normal e determinou minha trajetória. Os caminhos trilhados a partir daí me conduziram ao mestrado.

Os aspectos ligados à infância acompanham desde os primeiros passos da minha formação. Na graduação no Curso de Pedagogia no ano de 1997, na Universidade Federal Fluminense (UFF), tive a oportunidade de desenvolver um estudo sobre a formação dos professores que trabalhavam na Educação Infantil, abordando questões relativas ao nível de formação dos mesmos e sobre os motivos que os levaram a escolha pelo magistério.

Ao término da graduação ingressei no Curso de Especialização em Educação Infantil: Perspectivas do trabalho em creches e pré-escolas na PUCRio, no ano de 2002. Com as leituras e as inquietações advindas da prática, conclui este curso com a elaboração da monografia: "Reflexões sobre memóriahistória da infância em Tanguá". Este estudo aprofundou em mim o desejo de pesquisar as memórias de infância da cidade onde moro e a importância desta memória para ensinar às crianças a história da cidade. Além desta questão surgiram outras como: qual o lugar da infância na história da cidade? Que relação a cidade possui com as crianças no decorrer de sua história?

Há anos venho me tornando prisioneira dessas ideias, juntando as histórias contadas pelos meus avós e por outros moradores antigos, com minha própria história de vida. No mestrado retomo este desafio de estruturar tais pensamentos à luz de uma teoria que possibilite maior embasamento para a compreensão de tantas histórias.

A pesquisa foi realizada na cidade de Tanguá, localizada na Região Metropolitana do Estado do Rio de Janeiro. Há 60 quilômetros da capital do Estado, Tanguá faz limite com os municípios de Maricá, Itaboraí, Rio Bonito, Saquarema e Cachoeiras de Macacu. Segundo dados do Instituto Brasileiro de Geografia e Estatística - IBGE, Tanguápossui uma área terrestre de 143,7 Km, e cerca de $20 \%$ do território é considerado urbano e $80 \%$ rural. A população encontra-se em torno de 30.732 habitantes (IBGE - Censo 2010). 
A história de Tanguá encontra-se vinculada à de Itaboraí, município do qual foi sede distrital até 1995, quando alcançou sua emancipação com a edição da Lei Estadual $\mathrm{n}^{\circ} 2.496$, em 28 de dezembro de 1995, e instalação em $1^{\circ}$ de janeiro de 1997. Assim, no ano de 2016, completou 21 anos de emancipação e 18 anos de administração política.

A origem do nome encontra-se na língua tupi: tan significa "formiga" e guaquer dizer "comer". Assim, traduzida literalmente, Tanguá significa "comer formiga" ou "papa formiga". O primeiro registro da origem do povoado de Tanguá data de 1670, que surge na forma de uma sesmaria de nove léguas quadradas concedida ao Alferes Henrique Duque Estrada. Segundo registros oficiais, a colonização da região de Tanguá se deu com o cultivo de cana-deaçúcar. Em março de 1878, Tanguá recebeu seu primeiro trem com a construção de uma linha férrea que ligava o litoral de Niterói ao norte do Estado.

Tanguá sofreu transformações socioeconômicas decorrentes do seu desenvolvimento, principalmente com a criação da Usina de Açúcar no ano de 1920 (primeira usina da região). No mesmo ano, saiu da condição de povoado para tornar-sedistrito de Itaboraí. A usina foi adquirindo grandes extensões de matas para cultivar a cana-de-açúcar e assim prover seu próprio abastecimento e também se utilizava da produção de alguns fazendeiros e pequenos produtores. Todavia, problemas econômicos fizeram com que a usina fosse leiloada, sendo adquirida pelo senhor Manoel João Gonçalves na década de 1930.

Sob o comando da família Gonçalves, a Usina operou significativas mudanças na vida da cidade. Primeiro, tornou-se a principal fornecedora de empregos para uma população que vivia basicamente da produção familiar; segundo por organizar e fornecer serviços essenciais e atividades de lazer para a população, tais como: hospital, casas para os empregados, cinema, festas para comemoração das safras, patrocínio de festas religiosas e a construção da Igreja Católica da cidade, a Igreja Nossa Senhora do Amparo, realizada a pedido da esposa do senhor Manoel João Gonçalves, a senhora Tereza Campins Gonçalves, no ano de 1960.

Tanguá também viveu momentos significativos em sua história com a chegada da estrada Norte Fluminense que ligava Niterói a Campos, e que hoje compõe a Rodovia Federal BR 101. Aos poucos, tornou-se uma cidade com o 
comércio crescente e com o movimento intenso de imigrantes que vieram do norte do Estado e de Estados vizinhos, como Minas Gerais e Espírito Santo.

Na década de 1940 a Usina fez a doação de um terreno ao Governo Estadual para a construção da primeira escola oficial da cidade, o Colégio Estadual Antônio Francisco Leal. Anos depois a Usina começou a apresentar declínio frente à crise que o açúcar sofreu no mercado mundial. Ao contrário da fase anterior de prosperidade e desenvolvimento, Tanguá iniciou um difícil período socioeconômico. Muitas pessoas ficaram desempregadas e partiram rumo a outras cidades a procura de trabalho. O terreno da Usina Tanguá foi compradomais tarde pela Companhia Brasileira de Antibióticos - CIBRAN, instalada na cidade até final dos anos 1990. Com o decorrer dos anos, outros investimentos foram chegando a Tanguá, configurando o que vivemos hoje após sua emancipação do município de Itaboraí.

Este breve histórico da cidade de Tanguá, fornece umabase de informações que ajudam a compreender um pouco como foi o desenvolvimento da população tanguaense. No entanto, o que me fascina e que busquei estruturar nesta pesquisa,são as histórias não oficiais, aquelas que ouvi dos meus avós e de meus pais quando era criança. Sendo assim, as narrativas develhos moradores, foi o caminho escolhido paraencontrar uma história de Tanguá que poucos conhecem, mas que está lá guardada na experiência de vida daqueles que viveram boa parte da história. Nas narrativas o trabalho com a memória é o fio condutor, todavia não a memória nostálgica, onde passado é visto como um tempo melhor que hoje (BOSI, 2015). Esta pesquisa trabalha com a memória como busca da reflexão do passado para entender o presente, e assim, encontrar alternativas para construção do futuro (BENJAMIN, 2012).

\subsection{O encontro com os autores: concepções teóricas e levantamento bibliográfico}

Nas últimas décadas no campo educacional, pesquisas procuram ouvir as vozes dos professores, das crianças e das famílias dentro do contexto da Educação Infantil. No entanto, poucos estudosfocalizam ou priorizam vozes dos velhos moradores de uma cidade, suas memórias, suas histórias de vida e a construção da relação entre estas lembranças com o trabalho da Educação Infantil. Esta pesquisa 
se propõe a ouvir as lembranças de infância dos velhos moradores de Tanguá, pois escutar as histórias de vida desses moradores é ouvir a sociedade na qual estão inseridos. A memória do indivíduo depende do seu relacionamento com a família, com a classe social, com a escola, com a igreja, com a profissão, enfim, com os grupos de convívio e os grupos de referência peculiares a esse indivíduo (HALBWACHS, 2004).

Para Halbwachs, a memória é fundamentalmente coletiva e social. $\mathrm{Na}$ construção de nossas lembranças nunca estamos sós, levamos conosco certa quantidade de indivíduos e experiências vividas. Neste estudoa contribuição deste autor é extremamente relevante, pois para o mesmo lembrar não é reviver, mas refazer, reconstruir, repensar, com imagens e ideias de hoje, as experiências do passado. Para Halbwachs (2004) rememorar é entrelaçar presente, passado e futuro, e neste aspecto o mesmo se aproxima de Walter Benjamin.

ParaHalbwachs e paraBenjamin, a memória não é um fenômeno meramente individual, mas construído coletivamente. Para Benjamin é preciso rememorar para "escovar a história a contrapelo" (2012, p. 219), rompendo com a linearidade e com a superficialidade da história oficial. As memórias dos velhos moradores oferecem a possibilidade de escovar a história oficial "a contrapelo" e assim revelar outras histórias que poucas vezes foram contadas e valorizadas.

Benjamin (2012) ainda traz ricas contribuições quando fala sobre a perda da experiência humana na era capitalista. Com a industrialização e seus gestos repetitivos e mecânicos,a experiência humana se empobrece. Como consequência, os homens perdem a capacidade de construir uma visão crítica da história e o vínculo com sua tradição cultural. Tais fatos ocasionam também a perda da faculdade de intercambiar experiências,o que provoca a extinção da arte de narrar. Benjamin nos faz refletir sobre estes fatos, e assim, traz ricas contribuições a esta pesquisa que tem como perspectiva trilhar o sentido contrário do caminho que tem trilhado a modernidade, e procuraa valorização da experiência humana através da arte de narrar e contar histórias de vidas.

Ecléa Bosi (2015) em sua obra "Memória e Sociedade: Lembrança de Velhos" procuranas narrativas não só a memória pessoal, mastambém a memória social. Segundo a própria Ecléa Bosi, a estrutura da obra tem algo de funil: começa pela reflexão mais geral sobre o fenômeno da memória em si, passa a marcar seu nexo íntimo com a vida social (Capítulo 1); procura entender a função 
da memória na velhice (Capítulo 2); transcreve em seguida o resultado das entrevistas com os oito sujeitos (Capítulo 3); para enfim, comentar os resultados e segurar alguns fios teóricos desenrolados desde o princípio do trabalho.

Para realizar a tarefa de entendimento das narrativas, Bosi (2015) baseia-se em reflexões sobre memória deHenri Bergson, Maurice Halbwachs, FredericCharles Bartlett e Willian Stern. Baseia-setambém em estudos de Simone de Beauvoir sobre a velhice e análises de Walter Benjamin sobre o processo narrativo. DizBosi: "não pretendi escrever uma obra sobre memória, tampouco sobre velhice. Fiquei na intersecção dessas realidades: colhi memórias de velhos"'(2015, p. 39).

Ao transmitir as memórias de infância dos velhos moradores, a pesquisa valoriza a arte de narrar. Com a modernidade, estas duas práticas foram substituídas pela notícia e pelo romance. Ambos rápidos e ligeiros e não existe a possibilidade de serem medidos pelo bom senso do leitor. Sendo assim, onde fica a experiência que é passada de boca em boca? Parece que ficamos mudos frente às experiências mecânicas que se tornou o nosso viver.

Comprovamos com a correria do nosso dia a dia que são cada vez mais raras as pessoas que sabem narrar. Onde estão os narradores anônimos que tiram de suas experiências os conselhos? "Conselho tecido na substância da vida vivida e tem um nome: sabedoria" (BENJAMIN, 2012, p. 217). Para esta pesquisa estes narradores são os velhos moradores dacidade, pois estes representam “... o homem que ganhou honestamente sua vida sem sair do seu país e que conhece as histórias e as tradições" (BENJAMIN, 2012, p.214).

Reconstruir as memórias de infância é conhecer uma riqueza e uma diversidade que não conhecemos. Momentos de um tempo perdido podem ser compreendidos por nós, que não os vivenciamos, e conhecer este passado pode humanizar o presente. Segundo Bosi (2015, p.83):"na sociedade industrial o adulto não dispõe de tempo ou desejo para reconstruir a infância, já o velho se curva sobre ela como os gregos sobre a idade de ouro".

Walter Benjamin tem o idoso como o guardião da tradição e da experiência. Para ele, o idoso toma a infância na perspectiva de outras temporalidades e esta não se esgota na experiência vivida, mas é ressignificada na vida adulta por meio da rememoração. Com a ajuda de Benjamin, podemos refletir que ao falar da infância, o velho se reporta às lembranças do passado, não como este de fato 
ocorreu, mas a um passado que é recontado a partir do crivo do presente, e que se projeta prospectivamente.

Willian Corsaro (2011) também traz grandes contribuições a este estudo, como um dos maiores representantes desta nova corrente da Sociologia, seu foco está na infância como uma construção social resultante de ações coletivas de crianças com adultos e de crianças umascom as outras. Para Corsaro (2011), a infância é uma forma estrutural da sociedade e as crianças são agentes sociais que contribuem para a reprodução da infância na própria sociedade. Isso acontece por meio de suas negociações com adultos e de sua produção criativa com outras crianças.

Nesta nova visão da infância como um fenômeno social, Corsaro (2011), substitui a noção tradicional de Socialização pelo conceito de Reprodução Interpretativa. A Reprodução Interpretativa reflete a participação crescente das crianças em suas culturas, essa participação começa na família e se espalha para outros ambientes da sociedade, tendo como base a estrutura institucional da cultura adulta. Corsaro (2011) contribui com o estudo das memórias de infância em Tanguá, na medida em que a noção de Reprodução Interpretativa desafia a estudar as crianças com cuidado e a apreciar as contribuições infantis, seja pela memória, seja pelas vivências atuais para a reprodução e para a mudança social.

Assim, as memórias de infância podem ajudar adultos e crianças a descobrirem, juntos, signos perdidos, caminhos e labirintos que podem ser retomados, continuações de histórias interrompidas. Recuperar para o futuro os desejos que não se realizaram, as pistas abandonadas, as trilhas não percorridas é uma forma do velho morador de Tanguá intervir na história da cidade. Nesse sentido, a experiência da infância construída na narrativa é a memória daquilo que poderia ser diferente, isto é, a releitura crítica no presente da vida e da infância. Nesta perspectiva,se justifica ouvir velhos moradores da cidade para ajudar a se revelar o lugar da infância na cidade de Tanguá.

Um levantamento bibliográfico das produções acadêmicas sobre memórias de velhos moradores ou memórias de infância dos últimos anos revelou poucos estudos nessa área, principalmente quando se buscou a relação entre memórias de velhos moradores e a Educação Infantil, ressaltando assim a importância e a relevância do estudo aqui apresentado. Em consulta ao Banco de Teses e Dissertações da CAPES foram encontrados 3.703 registros para o descritor 
memória e 20 registros para o descritormemórias de infância. Dentre as teses e dissertações que tratavam o tema memórias de infância, três trabalhos apresentaram significativas contribuições à pesquisa sobre memórias de infância em Tanguá; nestes trabalhos a memória de velhos moradores da cidade foi oponto de partida para várias análises sobre a infância e a história de vida em bairros e cidades.

"Por uma estética da delicadeza: ressignificando contos e imagens nas roças de Minas" é uma Dissertação de Mestrado do Departamento de Psicologiada PUC - Rio, elaborada por Denise Sampaio Gusmão sob a orientação da professora Solange Jobim e Souza e apresentada em março de 2004. O estudo narra o encontro entre uma pesquisadora, uma escritora mineira e um pequeno povoado situado na região leste de Minas Gerais - o Córrego dos Januários. Esta localidade, assim como outros povoados do Brasil, se deparou com as mudanças no seu cotidiano deflagradas com a chegada da luz elétrica e da televisão, ameaçando a história e a memória de seus habitantes. A pesquisa começa com o desejo de Maria de Lourdes Souza - a escritora mineira - de registrar casas, histórias e costumes ameaçados de desaparecer no lugarejo onde nasceu, viveu a maior parte de sua vida e que constitui sua fonte deinspiração como escritora. A pesquisadora conhece Maria de Lourdes e deste encontro nasce a possibilidade de juntas recuperarem a história dos Januários.

Baseada nos escritos de Benjamin sobre experiência, história e narrativa e o conceito de memória na obra de Ecléa Bosi, Gusmão (2004)inicia sua viagem na história e na memória dos moradores do Córrego dos Januários. Foram cinco viagens à cidade em busca das memórias e na tentativa de compreender o que levava o Córrego a ter ameaçados de extinção valores e costumes que marcaram a sua identidade. Gusmão (2004) também utilizou o recurso da fotografia com o objetivo de não guardar somente narrativas, mas guardar também as imagens do processo percorrido.

Este estudo se divide da seguinte forma: "Imagens, Narrativa e História: era uma vez o Córrego dos Januários”, onde a pesquisadora conta como conheceu Maria de Lourdes e como chegou até o lugar da pesquisa;“Terra e Memória: escavando contos e imagens nas Gerais" - com a ajuda de Walter Benjamin a autora vai redescobrindo a história e relata como atravésda realização de oficinas propicia o encontro entre crianças e adultos. Faz também uma análise desse 
encontro de gerações. Na terceira parte deste estudo, a pesquisadora narra toda a experiência com a fotografia, incluindo as oficinas onde os moradores registraram, pela primeira vez, seus olhares. E, na quarta parte, procurou pensar sobre a relação entre crianças e velhos, fazendo a ponte entre as experiências e as histórias contadas, realizando assim, uma reflexão sobre o papel da educação. Esta parte da dissertação é surpreendente, pois ao final dos trabalhos, Maria de Lourdes escreve um livro sobre a história dos Januários. Este livro é trabalhado com as crianças na escola da cidade e são realizadas atividades entre as crianças e os velhos moradores.

Adissertação de Gusmão muito se aproxima do objeto de estudo da pesquisa "Um olhar no passado: Memórias de infância em Tanguá", porque ambas são movidas pela mesma preocupação: a perda da memória e o empobrecimento da experiência humana como fala Benjamin(2012). Relacionando a história de Tanguá com a história do Córrego dos Januários revela-se uma realidade semelhante: a modernidade trouxe mudanças significativas na vida dos cidadãos e o empobrecimento das relações com a perda da arte de narrar. Na dissertação de Gusmão(2004) destaco o encontro de gerações que acontece no final da pesquisa - crianças e velhos moradores realizando atividades juntos na escola - o velho se encontra com o novo gerando a possibilidade de ações futuras.

“As dimensões lúdicas da experiência de infância: entre os registros de brinquedos e brincadeiras da obra de Franklin Cascaes e a memória de velhos moradores da Ilha de Santa Catarina e de velhos açorianos de "Além-Mar" é uma tese de doutorado elaborada por Francisco Emílio de Medeiros e apresentada no Departamento de Educação Física na Universidade Federal de Santa Catarina sob a orientação da professora Ana Maria Silva e co-orientação do professor Maurício Roberto Silva. O estudo busca nas memórias dos velhos moradores da Ilha de Santa Catarina e nas memórias de velhos moradores dos Açores em Portugal, o registro das experiências lúdicas do tempo de criança. Estas lembranças são comparadas com os registros de brincadeiras presentes na obra de Franklin Cascaes, pesquisador da cultura açoriana, folclorista, ceramista, antropólogo, gravurista e escritor brasileiro que dedicou sua vida ao estudo da cultura açoriana na Ilha de Santa Catarina e cuja obra foi divulgada apenas em 1972. A reflexão do autor sobre a brincadeira é a mais significativa base teórica deste estudo. 
A tese se estrutura da seguinte forma: Primeiro são apresentados os aspectos do itinerário de realização da pesquisa, como opção teórico-metodológica e a escolha do campo empírico. $\mathrm{Na}$ sequência o pesquisador escreve sobre as reflexões que buscam dar respostas à questão investigativa. São colocadas às unidades temáticas (categorias) de análise que emergiram do campo empírico e as categorias de análise teórica que irão dar forma e conteúdo aos subcapítulos que se seguem nesta parte do trabalho. No capítulo: "Brinquedos e Brincadeiras na Memória de Infância de Velhos a partir dos registros de Franklin Cascaes", Medeiros (2011) traz as memórias de infância dos entrevistados. Num primeiro momento,faz-se a relação entre os registros lúdicos na obra de Cascais e as semelhanças com as memórias dos entrevistados e, num segundo momento, apresentam-se as diferenças entre o brincar de ontem e de hoje. Para finalizar fragmentos da memória dos entrevistados são relacionados com os locais da Ilha de Santa Catarina e da Ilha dos Açores e com os locais que aparecem nas obras de Franklin Cascaes.

Este estudo traz importantes contribuições para a realização da pesquisa sobre memórias de infância em Tanguá. Primeiro, o fato de combinar a releitura da obra de Franklin Cascaes com as memórias de infância de velhos moradores verificando se estas experiências lúdicas permanecem ou não, pensando sobre o que ocasionou tais mudanças. O segundo aspecto diz respeito à análise dos resultados de tais rememorações, que podem ser importantes contribuições para se repensar os processos formativos das crianças hoje. Ao revelar os elementos lúdicos marcantes nas vidas das crianças de ontem, podemos ressignificar a experiência lúdica das crianças de hoje. A terceira questão: a partir de fotografias antigas das ilhas, pretendeverificar se os espaços de brincar de hoje são semelhantes aos espaços de brincar do passado.

"A História Oral de Vida de Moradores do Bairro Ibitiruna de Piracicaba SP: Contribuições à Educação Ambiental”, terceiro e último estudo analisado, é uma dissertação de mestrado elaborada por Vanessa MinuzziBininoto e apresentada na Universidade Metodista de Piracicaba em novembro de 2011, sob a orientação da professora Maria Guiomar Carneiro Tomazello. Esta dissertação estuda a história oral de vida de velhos moradores da zona rural de Piracicaba - SP com desdobramentos para a educação ambiental. São analisados depoimentos de velhos moradores do bairro de Ibitiruna, tendo como objetivo identificar, nestas 
lembranças, temas e aspectos da vida possíveis de serem trabalhados em projetos e atividades de educação ambiental.

No sentido de atingir o objetivo proposto, o trabalho abordou asmotivações que levaram a investigar o tema, seus objetivos e metodologia. Na segunda parte, a pesquisadora relata que foi necessário um estudo teórico capaz de dar suporte à construção das histórias de vida e, por este motivo, a segunda parte da dissertação "Memória e História Oral", traz uma revisão bibliográfica sobre Memória, História Oral e suas relações. Logo em seguida, a pesquisa traz as narrativas dos sete moradores entrevistados. No capítulo "O recorte temático da pesquisa: educação ambiental" são analisadas as definições e propósitos da educação ambiental, sua relação com qualidade de vida e com a educação no campo. A dissertação é concluída com a análise das entrevistas e com aproblematização dequestões no âmbito da educação ambiental.

O segundo capítulo apresenta autores como Maurice Halbwachs, Ecléa Bosi, Michael Pollak e Henri Bergson numa construção teórica significativa, com o objetivo de embasar o trabalho com Memórias e Histórias de vida. A busca no passado de pistas para uma educação ambiental mais consciente no presente foi algo inovador e que nos faz, ao ler o trabalho, ter uma postura reflexiva diante da educação ambiental e como ela vem acontecendo nas escolas e nas cidades nos dias atuais. Nos depoimentos dos velhos moradores são encontrados os "conselhos", tal qual apresenta Benjamin (2012), e em suas narrativas existe a possibilidade de entrecruzar presente, passado e futuro, pois, segundo a pesquisadora, as soluções para uma educação ambiental de qualidade não estão somente no hoje, mas encontram-se na participação das várias gerações para juntos pensarem como preservar o meio ambiente no pequeno bairro de Ibitiruna de Piracicaba - SP.

Ainda como parte deste levantamento bibliográfico foi realizada para a presente dissertaçãouma busca detalhada nos principais periódicos sobre educação do país - Educação e Realidade, Educação e Sociedade, Educação e Pesquisa, Educação em Revista, Revista Brasileira de Educação e Revista Educação (PUCRS). Apresento os artigos encontrados a partirdos descritores: memórias de infância ememória de velhos moradores, que trazem aproximações com a pesquisa Memórias de infância em Tanguá. 
Na Revista Educação e Sociedade no ano de 2015, volume 26, foi publicado o artigo: "Walter Benjamin e a experiência infantil: contribuições para a educação infantil", escrito por Sandro Vinicius Sales dos Santos, aluno da Universidade Federal de Minas Gerais, o artigo traz contribuições para se pensar a infância na atualidade, tendo como embasamento teórico as contribuições do pensamento benjaminiano sobre a infância. Este trabalho discute o conceito de experiência na obra do autor, partindo do pressuposto que a experiência infantilse distingue da experiência vivida pelos adultos, na medida em que as crianças possuem formas peculiares de ser e estar no mundo. Durante todo o artigo, é apresentada a complexidade do pensamento de Walter Benjamin e como este pensa e descreve a infância, trazendo contribuições para se pensar uma Educação Infantil com práticas pedagógicas emancipadoras da infância, que oportunizem a exploração do mundo, em vivências reais de ação reflexão, de crescimento e desenvolvimento. São estas contribuições que aproximam este artigo da pesquisa aqui proposta.

O artigo "Memórias sobre a História de uma cidade: a história como labirinto", escrito por Lana Mara de Castro Siman, foi publicado na Revista Educação em Revista no ano de 2008, volume 47. O artigo teve como motivação principal explorar as possibilidades da relação entre história e memória para o ensino da História das cidades e foi realizada na cidade de Governador Valadares em Minas Gerais. Primeiramente, a pesquisadora foi ao arquivo público da cidade e levantou uma documentação sobre a história, que permitiu um delineamento do perfil dos moradores que seriam entrevistados. Foram entrevistados velhos moradores que participaram ativamente da formação da vida econômica da cidade de Governador Valadares: empregados das minas de ferro, donos de comércio, advogados, professores, entre outros. Tratava-se de uma cidade onde os velhos moradores participaram de sua formação, e, por este motivo, poderiam ser narradores daquela história.

No decorrer do trabalho, são apresentadas partes destas narrativas, construindo relações entre a história oficial de Governador Valadares e as memórias dos velhos moradores, na perspectiva de não valorizar apenas a história dos vencedores, mas valorizar também a história dos vencidos - que poucos conhecem sobre a vida da cidade. Dessa forma, Benjamin ajuda a refletir, durante todo o estudo e ao final, sobre como podemos conhecer a história de uma cidade a partir da narrativa de seus velhos moradores. Este estudo se aproxima da pesquisa 
aqui proposta pelo fato de que a história oficial de Tanguá também pode ser revisitada pelas memórias de seus velhos moradores, e assim entrarmos no labirinto da história sem medo de nos perder, e nos reencontrarmos com a ajuda de Walter Benjamin em sua teoria crítica da história.

"Walter Benjamin e a infância: apontamentos impressionistas sobre sua(s) narrativa(s) a partir de narrativas diversas" é um artigo escrito por Rita de Cassia Marchi, professora da Universidade Regional de Blumenau, publicado na Revista Educação - PUC-RS no ano de 2011, volume 34. O artigo trata da infância como objeto de reflexão filosófica em Walter Benjamin. Os escritos de Walter Benjamin sobre a infância são tratados como precursores à obra de Philippe Ariès, que nos anos 1960 surpreendeu o mundo acadêmico com suaHistória social da criança e da família. A autora relata que diferente do pesquisador francês, Benjamin não realizou uma pesquisa histórica sobre o surgimento da infância na Europa, todavia já nos anos 20 do século XX, de forma sutil e marcante, eleva a criança ao estatuto de sujeito digno de observação e de se tomar nota.

$\mathrm{O}$ artigo convida a entrar nas camadas de sentidos dos escritos benjaminianos a respeito da infância, traz alguns fragmentos da obra "Infância emBerlim"destacando que, para além de uma aparente "biografia" ou atividade "memorialística", o que Benjamin faz ao escrever sobre fatos, emoções, personagens e objetos que povoam sua infância é atentar para uma infância que não é apenas particular, mas para uma infância que é universal. Benjamin, ao escrever sobre sua infância, não pretendeu a idealização desta, mas lembrar-se do passado permite a releitura crítica da vida do adulto e, assim há a possibilidade, através dessas lembranças, de decifrar o presente e retomar trilhas e caminhos possíveis de serem modificados. Refletir com Benjamin, sobre a infância éconstruir uma reflexão crítica sobre a sociedade que vivemos, e esta é agrande contribuição deste artigo para a pesquisa sobre as memórias de infância em Tanguá.

O artigo "A criança e a infância sob o olhar da professora de educação infantil" elaborado por Carla Tosatto e Evelise Maria Labatut Portilho foi publicado na Revista Educação em Revista no ano de 2014, volume 30. O artigo traz uma pesquisa realizada com os professores de uma escola municipal de Educação Infantil da Prefeitura Municipal de Curitiba - PR, no período de formação continuada das educadoras. Durante este tempo, as pesquisadoras 
buscaram os significados que estas profissionais atribuíam à criança e à infância, para que pudessem analisar a relação desses significados com a prática pedagógica desenvolvida na escola, refletindo acerca do lugar que a criança ocupa neste contexto. Foram realizadas entrevistas e observações e, com a interpretação dos dados, foram elaboradas unidades de significação, de acordo com o referencial teórico, possibilitaram a identificação das várias formas como as crianças são vistas pelas professoras dentro da instituição.

O cotidiano da Educação Infantil é marcado pela visão que os professores têm sobre as crianças, e isso se revela nos pormenores da prática docente: na organização do tempo e do espaço, nas propostas pedagógicas, nas interações e experiências, nas vozes que se expressam ou se silenciam (TOSATTO e PORTILHO, 2014). Desta forma, se justifica o valor desta pesquisa, que oferece aos professores a possibilidade de refletirem sobre a concepção que possuem acerca da criança e da infância, a fim de provocar novos olhares, novas interações e outras ações. Este estudo aborda os conceitos de infância presentes na ação pedagógica, e faz pensar sobre as concepções de infância que serão reveladas na pesquisa em Tanguá e que tipo de influências estas concepções exercem sobre a vida das crianças na cidade: na escola, no lazer, na saúde, enfim, em várias esferas da sociedade onde a criança se faz presente.

$\mathrm{O}$ artigo "História coletiva e construções subjetivas: uma trama de narrativas em uma creche comunitária", elaborado por Vanessa Ferraz Almeida e publicado na Revista Educação em Revista no ano de 2013, volume 29, complementa o estudo de Torsatto e Portilho (2014) por não trabalhar somente com concepções, ideias e conceitos a respeito da criança e da infância. A pesquisadora foi mais além quando buscou a história de vidas das pessoas que lidam com as crianças e que fundaram a creche comunitária num bairro pobre da periferia de Belo Horizonte. Histórias de vidas são tomadas como importante elemento da formação pessoal e profissional do sujeito e as memórias são consideradas como memórias coletivas do passado, consciência crítica do presente e premissa operativa do futuro.

No desenvolvimento do trabalho são entrelaçadas as memórias de infância e as ações cotidianas dos adultos para com as crianças. Lembranças de fome, violência e escassez dominam as narrativas dos adultos e são compreendidas pela pesquisadora como um tipo de "explicação" para determinadas ações e 
comportamentos que se diferem dos discursos prontos a respeito da criança. A creche aparece, em muitos relatos, como um lugar para comer, segundo a pesquisadora, isso se explica pela experiência de fome que muitos educadores relataram terem vivido naquele bairro durante suas infâncias, então, nenhuma criança pode "não comer tudo". Nesta pesquisa, podemos perceber que a história das educadoras, a reconstrução de suas memórias e narrativas se misturam com a constituição da creche e também com as histórias das famílias e das crianças. Portanto, uma aproximação com a história de cada uma das educadoras, suas origens sociais, as concepções construídas em torno de si mesmas e da sua profissão, assim como as concepções construídas em torno das famílias e das crianças, é fundamental para a compreensão das práticas institucionais cotidianas.

Os artigos apresentam análises diferenciadas, mas complementares, de como estudar e pesquisar as memórias de infância. Todos os cinco artigos ajudam a pensar como os estudos sobre as memórias de infância podem contribuir para uma Educação Infantil como prática emancipatória da infância. Práticas que oportunizem a exploração do mundo, ações de reflexão, crescimento e desenvolvimento. Isso através das memórias de infância dos adultos (velhos), pois com a releitura crítica do passado, podem surgir possibilidades de retomar o passado, decifrar o presente para trilhar outros caminhos no futuro (KRAMER, 2004).

Nos artigos, as histórias de vida apresentamum importante instrumento metodológico acompanhado da observação. Este aspecto chama a atenção para analisar o que não foi falado, mas está presente nos olhares e gestos dos entrevistados. Em muitas situações os gestos dizem mais que palavras e no caso das histórias de vidas, estar atento a este aspecto é fundamental. Como sugerem estes artigos, a observação acompanhará esta pesquisa.

\subsection{Histórias de vida: uma metodologia em busca das memórias de infância}

Esta é uma pesquisa sobre memórias de infância. Mas de quem escutar as memórias? Quem são os sujeitos capazes de buscar nas lembranças as experiências de infância? Segundo Bosi "a idade adulta é norteada pela ação presente e quando se volta para o passado é para buscar nele o que se relaciona 
com suas preocupações atuais. Lembranças de infância para merecer atenção do adulto são constrangidas a entrar no quadro atual” (2015, p. 76). O adulto não dispõe de tempo e desejo de reconstruir sua infância. Já os velhos, que se encontram libertos das atividades profissionais e familiares, se curvam sobre a infância "como os gregos sobre a idade do ouro" (BOSI, 2015, p.83).

A conversa evocativa de um velho é sempre uma experiência profunda; através dela, um mundo social, que não conhecemos, pode chegar-nos pela memória. Momentos desse mundo não conhecido podem ser compreendidos por quem não os viveu e até mesmo humanizar o presente. Neste sentido, memórias de velhos moradores de Tanguá são tomadas como ponto de partida para pesquisar o lugar da infância na vida da cidade. Para tal, é necessário conhecer as origens e as contribuições das histórias de vida para as ciências humanas.

Ao longo dos séculos, o relato oral tem se constituído como a maior fonte humana de conservação e difusão do saber. Contudo, a partir do século XVII, a busca de um caráter científico para as ciências humanas baseado na neutralidade científica e na objetividade positivista traz a crítica à utilização da tradição oral para a produção do conhecimento. E, assim, somente no século XX a fonte oral é reintroduzida como recurso metodológico para as pesquisas em ciências sociais (LELIS e NASCIMENTO, 2010).

A história de vida se insere na perspectiva das metodologias que tomam o discurso oral como fonte. O termo fonte oral é compreendido aqui como material recolhido por um pesquisador, através de depoimentos orais, para as necessidades de sua pesquisa, em função de suas hipóteses e do tipo de informações que the pareça necessárias possuir (LELIS e NASCIMENTO, 2010). A história de vida é a metodologia onde a subjetividade, a memória, o discurso e o diálogo estão presentes. Através da fala, o narrador analisa a sua existência ressignificando sua vida através do tempo. As histórias de vida podem ser consideradas como "uma ciência e arte do indivíduo" (PORTELLI, 1997, p.15). Contudo, ao nascer, o indivíduo é inserido num determinado grupo social, no qual desenvolverá sua socialização, aprendendo valores, conhecimentos, hábitos e habilidades. Neste sentido Lelis e Nascimento (2010, p.255) esclarecem que:

(...) as narrativas, embora feitas por indivíduos, evidenciam mais que elementos da existência individual, pois através delas é possível captar as relações do narrador com os membros de seu grupo social, sua profissão, sua sociedade. Busca-se, com as histórias de vida, atingir a coletividade de que seu informante faz parte. Vê-se o 
informante como representante da comunidade, através do qual se revelam os traços dela $(\ldots)$

Nessa perspectiva, cada indivíduo tem muito a dizer, não somente sobre suas experiências pessoais, mas também sobre o contexto onde essas experiências se forjam. As histórias de vida se colocam justamente no ponto de intersecção das relações entre o que é exterior ao indivíduo e o que ele traz no seu íntimo, possibilitando captar onde se cruzam o pessoal e o social. Destaca-se aqui a importância desta subjetividade como via de acesso não linear ao conhecimento do sistema social, porque a pessoa é sujeito ativo no processo de apropriação do mundo social, traduzido em práticas que manifestam subjetividades. Como afirmaram Lelis e Nascimento: "Uma história de vida não é um relatório de acontecimentos, mas a totalidade de uma experiência de vida comunicada" (2010, p.256).

As histórias de vida ganharam destaque nas pesquisas do campo da educação traduzindo uma preocupação com a produção de um conhecimento que possa ajudar a ver o indivíduo segundo a história do seu tempo, permitindo enxergar o encontro da história de vida com a história da sociedade e dessa forma contribuir para transpor uma visão puramente técnica dos processos educacionais (PENA,2015). Como metodologia de pesquisa no campo da educação, as histórias de vida ganharam força. Uma grande representatividade neste campo no Brasil é o CIPA- Congresso Internacional de Pesquisa (Auto) Biográfica, que ao longo dos últimos doze anos vem reunindo um número significativo de pesquisadores de diferentes nacionalidades e diversas áreas do conhecimento. O fórum de discussões acontece no Brasil, de dois em dois anos com o objetivo de colaborar para avanços da pesquisa científica com fontes biográficas e (auto)biográficas. A primeira edição do CIPA aconteceu no ano de 2004, na PUCRS - Porto Alegre e a última no ano de 2016, na Universidade Federal do Mato Grosso - UFMT.

Nesta linha, esta pesquisa valoriza a narrativa, que é uma forma artesanal de comunicação onde experiências são trocadas e nela o narrador deixa a sua marca "como a mão do oleiro na argila do vaso" (BENJAMIN, 2012, p.221). O narrador tira o que narra da própria experiência e a transforma em experiência dos que escutam. Valorizar a memórias de infância dos velhos moradores da cidade, através de suas narrativas, parece um caminho fecundo, pois significa ultrapassar 
certas representações que veem o velho de modo asséptico, pelo que fazem ou não fazem. É também uma forma de valorizar a experiência de onde se tira o conhecimento, o conselho, e as possibilidades de descobrir que o não está dito, o que se guarda nas dobras e no avesso das histórias.

Para trilhar o caminho das memórias de infância, a entrevista será o instrumento utilizado. A entrevista nesta pesquisa será o momento de entrar na história de vida dos entrevistados e embora o pesquisador conduza a conversa quem decide o que vai relatar é o narrador. Muito mais do que colher informações, o que pretende é conhecer, ouvir, compreender, criar um espaço de narrativa onde os sujeitos da pesquisa estabeleçam um diálogo (PENA, 2015).Para que a entrevista seja um espaço de narrativa torna-se necessário uma escuta atenta e ressignificação de suas histórias. “A entrevista recupera a trajetória do sujeito e, ao mesmo tempo, insere e abre um novo espaço ou um espaço para o novo na própria história de cada um" (KRAMER, 2001, p. 177).

Diferente dos modelos de entrevistas comumente utilizados na pesquisa educacional (entrevistas estruturadas ou semiestruturadas), o aporte metodológico dessa pesquisa abre portas para que o velho morador da cidade fale de um interesse comum: suas memórias de infância em Tanguá. Para que a narrativa flua foi elaborado um roteiro que tem como objetivo captar os principais aspectos relativos à experiência de infância vivida na cidade. $\mathrm{O}$ roteiro tem os seguintes tópicos: Família; Escola; Brincadeiras; Brinquedos; Lugares da cidade percorridos na Infância; Trabalho; Diversão; Religiosidade; Festividades; Alegrias; Tristezas; Concepção de infância e de Educação.

Esta pesquisa não visa conhecer somente o que narram os entrevistados, mas também os recursos emocionais e corporais mobilizados em suas falas, ou seja, como constroem seus discursos (PENA, 2015), o que dizem e como dizem. Como escreve Bosi (2015):“... a arte de narrar é uma relação alma, olho e mão: assim transforma o narrador sua matéria, a vida humana” (p.49). Nesta pesquisa, a entrevista é diálogo, é encontro. Mais do que a aplicação de perguntas, a entrevista visa a construção e reconstrução de sentidos. Visa escovar a história de Tanguá a contrapelo (KRAMER, 2009). 


\section{O reencontro com os autores}

Uma lembrança é diamante bruto que precisa ser lapidado pelo espírito.

(ECLEA BOSI, 2015, p.81)

Este capítulo é um reencontro com os autores que ajudaram a estruturar teoricamente o estudo das memórias de infância na cidade de Tanguá. Foram escolhidos como referências teóricas desta dissertação Walter Benjamim, Ecléa Bosi e William Corsaro, estes produziram obras que, por caminhos diferentes, valorizaram a narração, o encontro e a relação entre os seres humanos como princípio que permite a compreensão crítica da realidade, da história e a participação na vida social. Aqui estão suas relevantes contribuições que ajudam a compreender o lugar da infância na cidade de Tanguá ao longo da história, e a valorizar a narrativa no trabalho com crianças na Educação Infantil.

Numa pesquisa que trabalha com história de vidas, não se pode deixar de apresentar, mesmo que de forma breve, um pouco da trajetória dos autores para que possamos saber um pouco da história de cada um e do lugar de onde falam.

Walter Benjamin nasceu em Berlim em 1892. Graduado em Filosofia, doutorou-se em 1919, com a tese $O$ conceito de crítica de arte no Romantismo alemão. Tornou-se um dos pilares da escola de Frankfurt, mas dela posteriormente se afastou após uma maior aproximação com o materialismo dialético de Marx. Por sua origem judaica, sofreu com o nazismo, foi exilado da Alemanha, abrigando-se em países como Dinamarca, França e Espanha, onde se suicidou em 1940 devido ao avanço das tropas nazistas, após a tentativa frustrada de refugiar-se nos Estados Unidos. Benjamim fala sobre o valor da experiência humana, da importância da valorização da narração e da memória em tempos onde a humanidade mergulha na barbárie. Para ele, a memória do velho guarda a tradição e a sabedoria, sabedoria que é tecida na vida vivida e que passa de uma geração a outra através da arte de narrar.

Ecléa Bosi nasceu em São Paulo e atualmente é professora emérita da Universidade de São Paulo. Possui graduação em Psicologia (1966), mestrado em Psicologia Social (1970) e doutorado também em Psicologia Social (1971), todos pela Universidade de São Paulo. Possui grande experiência em psicologia com ênfase em psicologia social, pesquisou temas nas áreas de psicologia, memória e cultura. Autora de obras como: Memória e Sociedade, Cultura de Massa e 
Cultura Popular, O Tempo Vivo da Memória, entre outras. Ecléa Bosi, atualmente, é coordenadora da Universidade Aberta da Terceira Idade e seus estudos sobre memórias de velhos muito contribuíram para a pesquisa sobre o lugar do velho na sociedade industrial. Eclea Bosi elaborou um significativo e importante trabalho com estudos sobre a memória, memória que para ela, não é apenas uma memória pessoal, é também uma memória social, familiar e grupal.

Sua obra Memória e Sociedade: Lembrança de Velhos $(2015)^{2}$ é tomada como umas das referências para esta pesquisa por se tratar de um estudo sobre memórias de velhos, onde esta memória é tratada não como mera recordação nostálgica, mas como possuidora da função de "unir o começo ao fim, de tranquilizar as águas revoltas do presente alargando suas margens” (BOSI, 2015, p.82). Para Bosi, quando o velho lembra não é sonho é trabalho. E ao transmitir o que escutou dos velhos nas entrevistas, revela o desejo de expor o pensamento de Walter Benjamim sobre a arte de narrar. Tanto para Bosi quanto para Benjamim "o velho tem o talento de narrar, talento que vem da experiência, de uma lição que extraiu da própria dor e sua dignidade vem de contá-la até o fim, sem medo" (BOSI, 2015, p.91).

William Arnold Corsaro, sociólogo americano, é professor titular da Faculdade de Sociologia da Universidade Indiana, nos Estados Unidos. Possui bacharelado em Sociologia pela Universidade de Indiana, título conquistado em 1970 e doutorado pela Universidade da Carolina do Norte, obtido em 1974. Entre seus os principais temas de investigação estão a Sociologia da Infância, as relações entre adultos e crianças, relações entre crianças e o processo de socialização. Muitos dos seus estudos focalizam a Cultura de Pares e a Educação Infantil. Ao abordar a socialização infantil, a ação social das crianças é compreendida como uma atuação mais interativa do que passiva ou meramente reprodutiva. E é neste aspecto que seus estudos contribuem significativamente para pensar a integração das crianças na vida social.

Segundo Corsaro, as crianças elaboram formas inovadoras e criativas de participarem da vida social e com base nesta premissa, esta pesquisa defende que as crianças não devem receber os dados do passado somente pela história escrita.

\footnotetext{
${ }^{2}$ Publicado pela primeira vez em 1979, a obra Memória e Sociedade: Lembranças de Velhos, representou um marco tanto para a pesquisa com histórias e vidas no Brasil como para a valorização do velho na sociedade.
} 
A elas deve ser dada a oportunidade de mergulharem em suas raízes através da história vivida, ou melhor sobrevivida, através das histórias de vidas de velhos moradores. Os velhos moradores podem tomar parte da socialização infantil, não apenas na família, mas dentro das instituições de Educação Infantil.

Benjamim, Bosi e Corsaro, como já foi citado anteriormente, construíram suas produções apoiados numa perspectiva de valorização da experiência humana para a construção de uma visão crítica da história. Suas produções fornecem elementos para se pensar como as memórias de infância de velhos moradores de Tanguá são um rico encontro com o passado e trazem em si a possibilidade de mudanças no presente e no futuro.

Dessa forma, este capítulo aprofunda os caminhos teóricos deste estudo, e apresenta os conceitos dos autores que ajudam na análise das histórias de vidas dos velhos moradores para a compreensão do lugar da infância na história da cidade de Tanguá.

\subsection{Histórias de velhos - Ecléa Bosi}

O primeiro desafio que, de início, se colocou à pesquisa foi trabalhar com histórias de velhos. A opção por utilizar o termo "velho" e não terceira idade, melhor idade, entre tantos outros termos que se referem à velhice, veio por acreditar que os atuais títulos conferidos àqueles que envelheceram deslocam a discussão para a questão da longevidade e o que esta pesquisa busca é analisar a função social do velho e o valor de suas memórias para a sociedade. Percorrendo o caminho de valorização do papel do velho na sociedade, Bosi (2015) escreve a obra Memória e Sociedade - Lembranças de Velhos que serve de referência para o estudo das memórias de infância em Tanguá. Logo na introdução da obra, Bosi (2015) escreve: "Este é um estudo sobre memórias de velhos. Para obtê-las, entrevistei longamente pessoas que tinham em comum a idade, superior a setenta anos, e um espaço social dominante em suas vidas: a cidade de São Paulo". (BOSI, 2015, p. 37)

Bosi (2015) esclarece não se tratar de uma obra que parte em busca de uma amostragem. O intuito foi registrar a voz e, através dela, a vida e o pensamento de pessoas que trabalharam por seus contemporâneos e por nós. Ainda, segundo a autora, este registro alcança uma memória pessoal que é também uma memória 
social. Memória e Sociedade - Lembranças de Velhos é uma obra que está situada na fronteira em que se cruzam os modos de ser do indivíduo e da sua cultura, fronteira que é um dos temas centrais da psicologia social:"A memória é um catedral infinito do qual só registramos um fragmento" (BOSI, 2015, p.39).

Para enfrentar o desafio do entendimento destes fragmentos registrados pela memória, a autora recorreu a estudiosos que concentraram na memória suas reflexões: Henri Bergson, Maurice Halbwachs, Charles Bartlett e William Stern. Merecem destaque também as obras de Simone de Beauvoir sobre a velhice e as análises de Walter Benjamim sobre o processo narrativo.

Segundo Bosi (2015), a estrutura da obra Memória e Sociedade - Lembrança de Velhos tem "algo de funil”, pois começa pela reflexão mais geral sobre o fenômeno em si para marcar o seu nexo íntimo com a vida social (capitulo 1); depois busca o entendimento da função da memória na velhice (capitulo 2); transcreve, em seguida, o resultado das entrevistas com os oito sujeitos (capitulo 3); para ao final comentar os resultados tendo como por base os conceitos teóricos construídos no início do trabalho (capítulo 4). Sobre sua obra BOSI (2015, p.39) esclarece:

Talvez deva insistir em duas negativas para delimitar bem o âmbito da obra: não pretendi escrever uma obra sobre memória, tampouco sobre velhice. Fiquei na intersecção dessas realidades: colhi memórias de velhos.

Nas lembranças, assim justifica Bosi (2015), é possível verificar uma história social bem desenvolvida. As pessoas velhas já atravessaram um determinado tipo de sociedade, com características bem marcadas e conhecidas, elas já viveram quadros de referência familiar e cultural igualmente reconhecíveis. Enfim, sua memória pode ser desenhada sobre um pano de fundo mais definido do que a memória de uma pessoa jovem, ou mesmo adulta, que de algum modo ainda está absorvida nas lutas e contradições de um presente que a solicita muito mais intensamente do que a uma pessoa velha. $\mathrm{O}$ adulto ativo não se ocupa longamente com o passado, mas quando o faz é como se este viesse em forma de sonho. Em outras palavras, para o adulto ativo, vida prática é vida prática, e memória é fuga, arte, lazer e contemplação. Situação bem diferente é a do velho:

Bem outra seria a situação do velho, do homem que já viveu sua vida. Ao lembrar o passado ele não está descansando, por um instante, das lides cotidianas, não está se entregando fugidiamente às delícias do sonho: ele está se ocupando consciente e atentamente do próprio passado, da substância mesma da sua vida. (BOSI, 2015,p.60) 
Haveria, portanto, para o velho uma espécie singular de obrigação social, que não pesa sobre os homens de outras idades: a obrigação de lembrar. Nem toda sociedade espera que os velhos se desencarreguem desta função, os graus de expectativa ou de exigência não são os mesmos em toda parte. $\mathrm{O}$ que se pode verificar na sociedade em que vivemos, é a hipótese mais geral de que o homem ativo (independente de sua idade) se ocupa menos de lembrar e exerce menos frequentemente a atividade da memória, ao passo que o homem já afastado dos afazeres mais prementes do cotidiano, se dá mais habitualmente à recordação do seu passado.

Se existe uma memória voltada para a ação, feita de hábitos e uma outra que simplesmente revive o passado, este segundo tipo de memóriaé a que caracterizaa dos velhos que já estão, em muitos casos, libertos das atividades profissionais e familiares. Se as atividades cotidianas pressionam e fecham o acesso a imagens de um outro tempo, a recordação parecerá algo semelhante ao sonho, ao devaneio, de tanto que contrasta com a vida ativa. Mas o velho não sonha quando rememora, ele desempenha uma função para a qual está maduro.

A idade adulta é norteada pela ação presente, e quando se volta para o passado é para buscar nele o que se relaciona com suas preocupações atuais. Lembranças da infância para merecer atenção do adulto são constrangidas a entrar no quadro atual. "Mas se o adulto não dispõe de tempo ou desejo para reconstruir a infância, o velho se curva sobre ela como os gregos sobre a idade de ouro" (BOSI, 2015, p. 83).

Através das lembranças dos velhos, um mundo social que possui uma riqueza e uma diversidade pode se descortinar. Momentos desse mundo perdido podem ser compreendidos por quem não os viveu e podem até mesmo humanizar o presente. Segundo Bosi (2015, p.82):

A conversa evocativa de um velho é sempre uma experiência profunda: repassada de nostalgia, revolta, resignação pelo desfiguramento das paisagens caras, pela desaparição de entes amados, é semelhante a uma obra de arte.

ParaEclea Bosi (2015), é preciso saber ouvir a conversa evocativa de um velho, pois para quem sabe ouvi-la ela é "desalienadora”, pois contrasta a riqueza e a potencialidade do homem criador de cultura com a mísera figura do ser consumidor do mundo atual. O homem não sabe o que ele é se não for capaz de sair das determinações atuais. "Uma lembrança é um diamante bruto que precisa 
ser lapidado pelo espírito" (BOSI, 2015, p.81). Sem o trabalho da reflexão, da localização e do sentimento, a lembrança seria apenas a repetição de um estado antigo, uma reaparição.

Ao transmitir as lembranças dos velhos que escutou, a autora expôs o que pensa Walter Benjamin sobre a arte de narrar:

Sempre houve dois tipos de narrador: o que vem de fora e narra suas viagens; e o que ficou e conhece sua terra, seus conterrâneos, cujo passado o habita. O narrador vence distâncias no espaço e volta para contar suas aventuras (acredito que é por isso que viajamos) num cantinho do mundo onde suas peripécias têm significação... (BOSI, 2015, p.84)

Desejou também ressaltar que a narração exemplar não está confinada nos livros, sua veia épica é oral. O velho tira o que narra da própria experiência e a transforma em experiência dos que o escutam. A narração das pessoas velhas é uma forma artesanal de comunicação. Ela não visa transmitir “em si” o ocorrido, ela tece até atingir uma forma. Investe sobre o ocorrido e o transforma. Uma tendência comum dos narradores é começar pela exposição das circunstâncias em que assistiu ao episódio: “Certa vez, ia andando por um caminho quando... isso quando o conta como não diretamente vivido por ele" (BOSI,2015,p.88)

Todas as histórias contadas pelos velhos inscrevem-se dentro da sua história, a de seu nascimento e toda a sua vida. Estas memórias do passado não anulam o tempo, mas o reconstrói. Ao fazer cair a barreira que separa o presente do passado, lança uma luz ao mundo atual: "lança uma ponte entre o mundo dos vivos e do além, ao qual retorna tudo o que deixou a luz do sol. Sendo assim, o passado revelado desse modo não é o antecedente do presente, é a sua fonte". (BOSI, 2015,p.89).

Esta fonte é desfrutada pelo narrador e pelo ouvinte, entre eles nasce uma relação baseada no interesse comum em conservar o que foi narrado e reproduzilo:

A história deve reproduzir-se de geração a geração, gerar muitas outras cujo fios se cruzem, prolongando o original, puxados por outros dedos. Quando Scheerazade contava, cada episódio gerava em sua alma uma história nova, era a memória épica vencendo a morte em mil e uma noites. (BOSI,2015,p.90)

Ao lado do ouvinte está o velho contando suas experiências. Suas mãos, experimentadas no trabalho, fazem gestos que sustentam a história, que dão asas aos fatos contados pela sua voz. Tira segredos e lições que estavam dentro das 
coisas. O velho tem o dom do conselho, pois a ele foi dada a capacidade de abranger uma vida inteira e seu talento de narrar vem desta experiência de vida.

Enquanto os pais se entregam as atividades da idade madura, a criança pode receber inúmeras noções dos avós e de outras pessoas velhas. Desta forma as experiências de vida e as histórias culturais chegarão até elas através de um narrador, que geralmente não tem a preocupação com o que é próprio para a criança, mas que conversa com elas de igual para igual, refletindo sobre acontecimentos políticos, históricos, tal como chegaram a ele através do imaginário popular.

Segundo BOSI (2015, p.74), graças a esta outra socialização é que a criança não estranha as regiões sociais do passado: ruas, casas, móveis, roupas antigas, histórias, maneiras de falar e de se comportar de outros tempos. Não só deixam de causar estranheza, como parecem singularmente familiares, devido ao contato: "O que é um ambiente acolhedor? Será ele construído por um gosto refinado na decoração ou será a reminiscência das regiões de nossa casa ou de nossa infância banhadas por uma luz de um outro tempo?” (BOSI, 2015, p.74)

Há dimensões de aculturação que, sem os velhos, não seria possível se alcançar plenamente: o reviver do que se perdeu de histórias e tradições, o reviver dos que já partiram e participam de nossas conversas e esperanças. Os velhos têm o poder de tornarem presentes na família os que já se ausentaram, pois deles ainda ficaram algumascoisas como nosso hábito de sorrir e de andar. A memória não deixa para trás estas coisas comodesnecessárias. A vontade de conhecer o passado arranca o seu caráter transitório, fazendo com que entre de modo construtivo no presente.

Esta essência da cultura pode atingir as crianças através da fidelidade da memória, onde correntes do passado só podem ser revividas através de certas pessoas: os velhos moradores de uma cidade.

\subsection{A Narração - Walter Benjamim}

Ouvir as histórias dos velhos moradores de uma cidade implica diálogo, subjetividade, escuta e narração, pois ao narrar, o velho entra em contato com o passado e ressignifica sua vida, tendo como referência o tempo presente. Para auxiliar na compreensão do processo narrativo e da relação deste com a memória, 
com a experiência e com a tradição, a pesquisa traz contribuições de Walter Benjamin.

Em seu ensaio Experiência e Pobreza, Walter Benjamin (2012) apresenta a tradição como fonte inesgotável de saber e aponta a memória como o modo de transmissão desse saber. A fábula do tesouro enterrado na vinha, apresentada no início de seu ensaio, é significativa pelo que expressa. Ao relatar um acontecimento em forma de parábola, Benjamin redimensiona o próprio acontecimento dando a ele novos sentidos. Assim narra Benjamin:

Em nossos livros de leitura havia a parábola de um velho que no momento da morte revela a seus filhos a existência de um tesouro enterrado em seus vinhedos. Os filhos cavam, mas não descobrem qualquer vestígio do tesouro. Com a chegada do outono, as vinhas produzem mais que qualquer outra região. Só então compreenderam que o pai lhes havia transmitido uma certaexperiência: a felicidade não está no ouro, mas no trabalho. (BENJAMIN, 2012, p.123)

Este relato acerca da experiência, fala sobre sua densidade e duração perpassados pela autoridade da tradição e que se manifesta na velhice. E fala também sobre a autoridade do saber da tradição, como sendo um saber atemporal, passível de ser transmitido de geração em geração. Há, neste breve conto, como afirma Benjamin (2012), a transmissão da experiência por meio de uma narrativa que ilustra sobre o verdadeiro tesouro que se encontra no trabalho. Esta mensagem implícita no corpo do texto serve como um conselho e uma sugestão. O aconselhamento,é para Benjamin (2012), a forma através da qual a experiência é transmitida. Experiência que é a matéria da tradição,transmitida pelo conselho e que ao logo do tempo se incorpora à tradição através da sabedoria.

A tradição é o espaço-tempo de um tipo peculiar de saber que está para além do racional e envolve um modo de vida. A tradição contempla um conjunto de representações significativas que condicionam o fazer e o saber de determinadas comunidades, ela é, em parte, o enquadramento de ações que não só ditam o modo do fazer, mas também, o modo de estar e o modo dos indivíduos se relacionarem uns com os outros e com o mundo. Podemos compreender a tradição como um elemento que congrega e mantêm vivos todos os saberes que perdurariam por sua eficácia e valor através dos tempos.

A tradição tem relação com a experiência e essa com a sabedoria. Para Benjamin, a sabedoria é o "conselho tecido na substância viva da existência" (2012, p. 217). É sábio, portanto, o individuo experiente, aquele sujeito que não só 
soube acolher a experiência viva da tradição, como também transmiti-la, comunicá-la e cuja sensibilidade foi capaz de chegar lenta e pacientemente a este modo de vida, onde a experiência serve de base a sabedoria. Não é apenas um conteúdo subjetivo de vida, mas também uma forma de relação com o mundo e com o outro, inimiga da pressa e do imediatismo. Esta é a sabedoria presente na narração que envolve muito mais do que uma experiência pessoal, mas envolve também uma experiência coletiva.

No ensaio O Narrador - considerações sobre a obra de Nicolai Leskov, Benjamin (2012) apresenta os aspectos que, para ele, teriam ocasionado o enfraquecimento de um gênero literário - a narração, e que viriam a acentuar ainda mais o declínio da experiência na sociedade moderna. Ao lermos "O Narrador" fica claro que, para o autor, o declínio da experiência decorre, em termos gerais, da perda do sentido de uma espécie de sabedoria ancestral e antiga. Isso ocorre em consequência de uma modernidade que chega imprimindo na cultura a desvalorização da tradição, a mudança de valores éticos e morais e a despersonalização do tempo por força dos novos meios de produção capitalista. Com a modernidade surgem também novos gêneros narrativos: o romance burguês e a informação jornalística, estes representam a valorização do mais fácil e imediato.

Em “O Narrador” Benjamin (2012) assinala que não só a experiência está em baixa, mas junto com ela a narração também corre o risco de extinguir-se. Isso se deve, fundamentalmente, ao apagamento da tradição na modernidade e ao empobrecimento das experiências coletivas plenas de sentido. Para Benjamin (2012), o homem moderno é pobre de experiência, é mudo, é alguém que nada tem a contar, pois nenhuma experiência possui, é um homem que não deixa rastros. É a humanidade se afundando em uma barbárie.

O narrador e sua narração estão repletos de elementos da tradição, que não se dão ao homem moderno, pois se tornou presa fácil de um tempo homogêneo, vazio, mecânico e sem significado. A tradição é comparada por Gagnebin (1999, p.58), "ao fio que tece a experiência e desta trama nasce a narração". A narração é um dos meios pelos quais a experiência da tradição é transmitida - e essa transmissão se dá em grande parte através da oralidade. Esta comunicabilidade oral foi fundamentalmente aquilo que se perdeu na modernidade. Com o gradual desaparecimento dessa espécie de comunicação, extingue-se também a figura do 
narrador como o sujeito que dá acesso aos conteúdos da tradição, aquele que é capaz de dar continuidade a uma história. Essa tradição, no entanto, como indica Gagnebin (1999, p.57) não configura apenas uma ordem religiosa ou poética:

...mas desemboca também, necessariamente, numa prática comum; as histórias do narrador tradicional não são simplesmente ouvidas ou lidas, porém escutadas e seguidas; elas acarretam uma verdadeira formação (Bildung), válida para todos os indivíduos de uma mesma coletividade.

O narrador é esta figura por intermédio da qual a sabedoria da tradição é transmitida. $\mathrm{O}$ narrador é identificado a partir do tipo de experiência que ele construiu, seja como aquele que reconhece, aceita e transmite os ritos e tradições de uma determinada comunidade; seja por aquele que conhece algo que se encontra longe e distante. Esses dois tipos de experiência compõem o narrador:

A figura do narrador só se torna plenamente tangível se tivermos presentes ambos esses grupos. 'Quem viaja tem muito para contar', diz o povo, e com isso imagina o narrador como alguém que vem de longe. Mas também escutamos com prazer o homem que ganhou honestamente sua vida sem sair do seu país e que conhece suas histórias e tradições. Se quisermos concretizar esses dois grupos através dos seus representantes arcaicos, podemos dizer que um é exemplificado pelo camponês sedentário, e o outro pelo marinheiro comerciante. De fato, ambos estilos de vida, produziram de certo modo suas respectivas linhagens de narradores. Cada uma delas conservou no decorrer dos séculos, suas características próprias. (BENJAMIN, 2012, p. 214)

O camponês sedentário conhece como ninguém o tempo, o seu lugar, suas histórias e tradições. Por nunca ter saído de sua terra pôde o camponês cultivar a memória daqueles que o antecederam, pôde ele manter presente o tempo passado. De um lado, encontra-se o marinheiro comerciante, um indivíduo cujo conhecimento e olhar têm uma amplitude, e do outro o camponês que construiu um olhar de profundidade.

Para Benjamin, é este conhecimento, que pode vir de perto ou de longe, que dá ao narrador a autoridade para narrar. Toda narração depreende uma moral da história e ela sempre resulta em numa sugestão prática. Sendo assim, Benjamin (2012) confere à narração uma dimensão utilitária e ao narrador uma função: "essa utilidade pode consistir seja num ensinamento moral, seja numa sugestão prática, seja num provérbio ou numa norma de vida"(BENJAMIN, 2012, p.216). Em qualquer um dos casos, o "narrador é (sempre) um homem que sabe dar conselhos". (BENJAMIN, 2012, p.216).

A narração restaura o passado e atualiza o presente (GAGNEBIN, 1999) Isso corresponde à função primordial do narrador: a de atualizar e transmitir a 
experiência e nesta experiência está a tradição. O narrador tem o compromisso com um saber objetivo sobre aquilo que é contado e este é o modo próprio de funcionamento do narrador que vê no aconselhamento sua forma aplicada. Para Benjamin, "aconselhar é menos responder a uma pergunta que fazer uma sugestão sobre a continuação de uma história que está sendo narrada" (BENJAMIN, 2012, p. 216).O narrador deixa a história em aberto com a intenção de multiplicar as possibilidades de reconstrução do que se encontra perdido ou esquecido no passado. Toda sugestão feita pelo narrador advém de um conhecimento aprofundado acerca daquilo que trata:

O conselho tecido na substância da vida vivida tem nome: sabedoria. A arte de narrar aproxima-se de seu fim porque a sabedoria - o lado épico da verdade - está em extinção. Mas este é um processo que vem de longe. E nada seria mais tolo do que ver nele um 'sintoma de decadência', e muito menos de uma decadência 'moderna'. Ele é muito mais um sintoma das forças produtivas seculares, históricas, que expulsam gradualmente a narrativa da esfera do discurso vivo, conferindo, ao mesmo tempo, uma nova beleza ao que está desaparecendo. (BENJAMIN, 2012, p. 217).

O saber de que dispõe o narrador não é um saber meramente técnico e nem um saber de si auto-referencial. Sua sabedoria implica no conhecimento histórico de formação de si em meio a um coletivo, do conhecimento das práticas, dos ritos e valores compartilhados e transmitidos pela tradição aos indivíduos. ParaGagnebin (1999) é justamente nesse contexto que a experiência, a Erfahurng, pode surgir, pois essa é a experiência que não reenvia o individuo à sua vida como um só, singular, solitário, mas como ser em meio a outros. "A história do si vai, pouco a pouco, preencher o papel deixado vago pela história comum..." (GAGNEBIN, 1999, p. 59). É exatamente sobre este sentido de comunitário que se sustentam, inclusive, a noção de trabalho, entre outras práticas sociais. Essa afirmação contempla, por sua vez, o caráter instrumental que caracteriza, de certo modo, a narração.

O modo de produção do ser da experiência e da tradição, constitui-se como uma dimensão existencial que nada tem a ver com a ideia moderna do trabalho, ou seja, com o modo de produção industrial, mecânico e desprovido de sentido.

Se narrar é a faculdade de intercambiar experiências, é também a faculdade de que dispõem aqueles que sabem trabalhar com o tempo; outra face da narração que obedece ao modo de produção artesanal, que é qualitativamente diferente do 
modo de produção capitalista. Narrar é uma arte, uma arte artesanal como uma das mais antigas formas de trabalho manual:

A narrativa que durante tanto tempo floresceu num meio artesão - no campo, no mar e na cidade -, é ela própria, num certo sentido, uma forma artesanal de comunicação. Ela não está interessada em transmitir o 'puro em si' da coisa narrada, como uma informação ou um relatório. Ela mergulha a coisa na vida do narrador para em seguida retirá-la dele. Assim, imprime-se na narrativa a marca do narrador, como a mão do oleiro na argila do vaso. (BENJAMIN, 2012, p.221)

Sendo a arte da narração uma forma de artesanato é o narrador seu artesão. A experiência é, com efeito, a matéria do narrador, assim como o barro é a matéria do oleiro. Como o artesão, o narrador nunca é alheio à sua obra, nesse caso, aquilo que conta. A narrativa como trabalho artesanal demanda tempo. E tempo suficiente para que seja possível fazer com que a tradição incida sobre ele.

A narração não se constrói na rapidez da técnica industrial, ela se constrói num tempo indefinido. O ritmo de trabalho apressado do trabalho industrial modificou por si mesmo a relação do homem como os acontecimentos, alterando a experiência que, no fundo, se vê degradada ao privar-se da lentidão (tempo necessário para o amadurecimento das experiências na tradição). Pode se dizer que para Benjamin (2012) o homem da era moderna não só não tem o que falar como não sabe escutar:

O tédio é o pássaro onírico que choca os ovos da experiência. O menor sussurro nas folhagens o assusta. Seus ninhos - as atividades intimamente associadas ao tédio - já se extinguiram nas cidades, e também no campo estão em vias de extinção. Com isso, desaparece o dom de ouvir, e desaparece a comunidade dos ouvintes. Contar histórias sempre foi a arte de contá-las de novo, e ela se perde quando as histórias não são mais conservadas. (BENJAMIN, 2012, p. 221).

O espaço no qual a narração pode frutificar é o espaço da memória, e o seu tempo não se mede pelo tempo cronológico. O tédio representa esse ânimo, que seria para Benjamin (2012) um estado de espírito que nega o tempo para tê-lo presente. Ele se abstrai do tempo presente para lançar-se à experiência do tempo narrado e assim a narrativa vai se desdobrando.

O trabalho artesanal da narração se constrói na tradição através da memória. Memória não só de acontecimentos, de técnicas e saberes práticos, mas de valores que se agregam apenas com o tempo. A narração faz convergir a história passada à história presente, ela torna-se consciência do presente e que não se orienta por uma concepção de tempo progressivo, mas intensivo.Para ser assimilada ela 
exige de seu ouvinte, tanto quanto de seu narrador, entrega e dedicação, sem pressa e nem intenção.

Com estas reflexões, fica o desafio de pensarmos a educação à luz da filosofia de Walter Benjamin, uma filosofia que ressignifica a experiência, resgata a narração e valoriza a tradição.

\subsection{A Infância - WilliamCorsaro}

Grande parte do pensamento sociológico sobre crianças e a infância deriva do trabalho teórico sobre Socialização - "processo pelo qual as crianças se adaptam e internalizam a sociedade" (CORSARO, 2011, p. 19). Em outras palavras, a criança, por muito tempo, foi vista como alguém apartada da sociedade, que deveria ser moldada e guiada, a fim de se tornar um membro totalmente funcional. Em consonância com a conviç̧ão de que as crianças são participantes ativas da sociedade, a pesquisa traz as contribuições de Willian Corsaro sobre o processo de socialização infantil, defendendo a necessidade de enriquecer as apropriações das crianças sobre o mundo adulto para incentivar as construções de suas próprias culturas e para compreensão das contribuições que as crianças podem dar para o mundo adulto. A pesquisa acredita que as memórias de infância dos velhos enriquecem as relações entre crianças e são fundamentais para o processo de socialização infantil.

Corsaro (2011) chama a atenção para processos diferentes de socialização que caracterizam modelos de inserção da criança na sociedade. Primeiro é o modelo determinista, no qual a criança desempenha um papel passivo e deve ser cuidada por meio de um treinamento rigoroso. O segundo é o modelo construtivista, onde a criança é vista como agente ativo e um ávido aprendiz, sendo capaz de construir ativamente seu mundo social. Este último trouxe importantes e significativas contribuições para pensar o processo de socialização infantil.

Para o autor, as teorias sociológicas da infância devem questionar a ideia de que o desenvolvimento social infantil se caracteriza, unicamente, como a internalização isolada dos conhecimentos e habilidades de adultos pelas crianças. A socialização não é apenas uma questão de adaptação e internalização, mas também um processo de apropriação, reinvenção e reprodução. Para Corsaro 
(2011) o problema está no próprio termo "socialização" que possui uma conotação individualista e progressiva, que é incontornável, e qualquer pessoa que ouça a palavra pensa imediatamente em formação e preparação da criança para o futuro. Corsaro (2011, p.32) propõe a noção de Reprodução Interpretativa, a qual define da seguinte forma:

O termo interpretativo abrange os aspectos inovadores e criativos da participação infantil na sociedade... o termo reprodução inclui a ideia de que as crianças não se limitam a internalizar a sociedade e a cultura, mas contribuem ativamente para a produção e mudanças culturais.

O termo Reprodução Interpretativa sugere que a própria participação das crianças na sociedade está restrita pela estrutura social existente e pela reprodução social. Isso significa que a criança e sua infância são afetadas pelas sociedades e culturas que integram e essas sociedades e culturas foram, por sua vez, afetadas e moldadas por processos de mudanças históricas.

A linguagem e a participação infantil em rotinas culturais são elementos essenciais da Reprodução Interpretativa. A língua é fundamental à participação das crianças em sua cultura como um "sistema simbólico que codifica a estrutura local, social e cultural e é uma ferramenta para estabelecer realidades sociais e psicológicas" (CORSARO, 2011, p.32). As rotinas culturais são elementos fundamentais por fornecer às crianças e, a todos os atores sociais, a segurança e a compreensão de pertencem a um grupo social. Essa previsibilidade fortalece muito as rotinas, fornecendo um quadro no qual uma ampla variedade de conhecimentos socioculturais pode ser reproduzida e interpretada. Portanto, "rotinas culturais servem como âncoras que permitem que os atores sociais lidem com a problemática, o inesperado e as ambiguidades, mantendo-se confortavelmente no confinamento amigável da vida cotidiana" (CORSARO, 2011, p.32).

Muitas teorias de desenvolvimento infantil concentram-se na criança isolada e adotam uma visão linear do processo de desenvolvimento. Esta visão supõe que a criança deva passar por um período preparatório na infância antes de poder evoluir para um adulto socialmente competente. Nesta perspectiva, o período da infância consiste num conjunto de estágios de desenvolvimento em que habilidades cognitivas, emoções e conhecimentos são adquiridos na preparação para a vida adulta. 
A Reprodução Interpretativa vê a interação das crianças em suas culturas como reprodutiva em vez de linear. De acordo com essa visão reprodutiva, as crianças não se limitam a imitar ou internalizar o mundo em torno delas. Elas se esforçam para interpretar ou dar sentido a sua cultura e participarem dela. $\mathrm{Na}$ tentativa de atribuir sentido ao mundo adulto, as crianças passam a produzir coletivamente seus próprios mundos. Para a Reprodução Interpretativa é importante a ideia de que a criança está sempre participando e integrando duas culturas: a das crianças e a dos adultos e que essas culturas são complexamente interligadas. Para entender a complexidade da integração evolutiva das crianças nessas duas culturas é preciso examinar suas atividades coletivas com outras crianças e com os adultos e considerar as crianças como parte de um grupo social que tem um lugar na estrutura social mais ampla.

A Sociologia da Infância apresenta a infância tanto como um período em que as crianças vivem suas vidas, quanto uma categoria ou parte da sociedade como classe social. Embora a infância seja um período temporário para as crianças, é uma categoria estrutural permanente na sociedade e ao colocar a infância como uma forma estrutural, a Sociologia da Infância ultrapassa as perspectivas individualistas dirigidas ao estudo da infância com o fim de examinar a vida adulta e limitada pelo passar do tempo.

Pensar a infância como categoria estrutural da sociedade abre a possibilidade de responder a uma ampla variedade de questões sociológicas que envolvem a vida infantil. Como categoria estrutural a infância passa a ser integrada à sociedade e, com isso, as crianças em suas infâncias particulares são como os adultos, participantes ativos das atividades em sociedade. Em suma, as crianças afetam e são afetadas por grandes eventos e transformações sociais.

O foco da Sociologia da Infância está na infância como uma construção social resultante de ações coletivas de crianças com adultos e de umas com as outras. Como escreve Corsaro (2011, p.56):

A infância é reconhecida como uma forma estrutural e as crianças, como agentes sociais que contribuem para a reprodução da infância e da sociedade, por meio de suas negociações com adultos, e de sua produção criativa de uma série de culturas de pares com outras crianças. Essa nova visão da infância como um fenômeno social substitui a noção tradicional de socialização pelo conceito de reprodução interpretativa. A reprodução interpretativa reflete a participação crescente das crianças em suas culturas, que começa na família e se espalha para outros ambientes à medida que as crianças criam uma série de Culturas de Pares integradas com base na estrutura institucional da cultura adulta. 
$\mathrm{Na}$ tentativa de atribuir sentido ao mundo adulto as crianças passam a produzir coletivamente seus próprios mundos e Culturas de Pares. Cultura de Pares é um conceito elaborado por Corsaro(2011) para explicar como as crianças se apropriam criativamente das informações do mundo adulto. Desde muito cedo, as crianças, começam a participar das rotinas culturais que envolvem interações com colegas em grupos de amigos, da pré-escola, entre outros. Nesta interação, produzem a primeira série de Culturas de Pares, na qual conhecimentos e práticas da infância são gradualmente transformados em conhecimentos e habilidades necessários para participar do mundo adulto. Corsaro (2011, p.151), assim conceitua Cultura de Pares:"Definimos culturas de pares como um conjunto estável de atividades ou rotinas, artefatos, valores e preocupações que as crianças produzem e compartilham em interação com outras crianças".

Este conceito de Cultura de Pares está em conformidade com o conceito deReprodução Interpretativa que destaca as ações coletivas das crianças, valores partilhados e ao lugar da participação infantil na produção cultural. As famílias desempenham um papel fundamental no desenvolvimento da Cultura de Pares, já que as crianças não vivem individualmente o ingresso no mundo, elas participam das rotinas culturais e as informações são primeiramente mediadas por adultos. No entanto, uma vez que as crianças começam a mover-se para fora da família, suas atividades com colegas e suas produções coletivas de uma série de culturas de pares tornam-se tão importantes quanto as interações com adultos.

Além das influências familiares na Cultura de Pares, Corsaro (2011) apresenta aspectos simbólicos e materiais da cultura infantil que influenciam as relações entre as crianças. Por cultura simbólica da infância aponta várias representações ou símbolos expressivos de crenças, valores e preocupações. As três fontes primárias da cultura simbólica da infância são: a mídia dirigida a infância (desenhos, filmes e outros), a literatura infantil (especialmente os contos de fadas) e os valores míticos e lendas (Papai Noel, a Fada do Dente e outros). As informações provenientes dessas três fontes são mediadas principalmente por adultos nas rotinas culturais em família e em outros ambientes e as crianças rapidamente se apropriam, usam e transformam a esta cultura simbólica, isso na medida que produzem e participam da Cultura de Pares.

A cultura material da infância se refere a vestuário, livros, ferramentas artísticas e de alfabetização (lápis de cor, canetas, papel, tintas, etc.) e mais 
especialmente brinquedos. As crianças podem usar, e muitas vezes o fazem, alguns desses objetos para produzir outros artefatos materiais das culturas infantis, como por exemplo: desenhos, pinturas, estruturas em blocos, brincadeiras improvisadas e rotinas e assim por diante. Estudos realizados por historiadores "mostram que à medida que as crianças desenvolvem-se como indivíduos, elas se apropriam coletiva e criativamente, usam e introduzem aos brinquedos significados, tanto na família quanto em suas Culturas de Pares" (CORSARO, 2011, p.145).

Como as Culturas de Pares ocorrem? Como seus elementos são compartilhados e transmitidos para outros grupos? Corsaro(2011) admite ser necessário avançar nas pesquisas com as crianças para responder estas perguntas. Segundo sua própria análise, a maioria dos estudos tem sido confinada a um único ambiente durante um período limitado de tempo. Poucos estudos seguiram as crianças à medida que faziam transições da família ao grupo de pares ou de uma Cultura de Pares para outra. Portanto, fica difícil responder tais questões. Mas mesmo assim, com suas pesquisas padrões foram observados, o que permite o esclarecimento de algumas questões.

As crianças são apresentadas a elementos de uma cultura mais geral de pares e a culturas locais específicas na família, isso por meio de irmãos mais velhos, pela televisão e por outros meios de comunicação e mesmo a partir dos pais. No entanto, as crianças ativamente ingressam e tornam-se participantes e colaboradores de Culturas de Pares locais pela primeira vez quando se movem para fora do âmbito familiar em direção à comunidade adjacente. Essa cultura inicial de pares pode assumir a forma de ligações vagamente estruturadas e de grupos de bairros. Nas sociedades ocidentais, principalmente em países em desenvolvimento, as crianças estão partindo rumo às creches e outros contextos educativos cada vez mais cedo. Dado o tempo que as crianças pequenas normalmente passam nesses ambientes e a intensidade das interações, esses ambientes frequentemente servem como eixo de uma rede integrada de ambientes ou regiões de pares. "É por meio de interação intensa e cotidiana nesse eixo que a primeira cultura local de pares se desenvolve e floresce" (CORSARO, 2011, p. 154).

Há uma ampla variedade de características das Culturas de Pares infantis todavia dois temas são centrais. O primeiro consiste em que as crianças fazem 
tentativas persistentes para obter o controle de suas vidas e o segundo é que elas sempre tentam compartilhar esse controle com as demais. Nos anos pré-escolares, as preocupações prioritárias são a participação social e a conquista do controle sobre a autoridade adulta. Como resultado dessa necessidade, é recorrente a preocupação das crianças pequenas com o tamanho físico e elas acabam valorizando as ações de crescer e "ser grande". Para as crianças pequenas, a característica distintiva entre elas e os adultos, é que eles são grandes (CORSARO, 2011, p. 155).

Impulsionados pelo desejo de "ser grande" e ter maior controle das suas vidas, as crianças desenvolvem uma série de curiosidades sobre o mundo adulto. Qual professor de Educação Infantil que nunca foi indagado pelas crianças a respeito da vida e de sua infância? Qual pai, mãe ou qualquer outro familiar que não foi questionado ou interrogado a respeito do seu passado? Será essa curiosidade infantil, a porta de entrada para um mundo desconhecido - o passado?O que a Educação infantil pode realizar para promover o encontro entre o passado e o presente?

Os três autores ajudam na compreensãodo valor das memórias dos velhos e da narração para o processo de socialização infantil. EcleaBosi, Walter Benjamin e Willian Corsaro compartilham a ideia de que a história é um processo vivo e não morto, e que esta porção viva da história pode ser transmitida pela voz e pelos gestos de quem a viveu. Esta narrativa que é singular, também é marcada pela humanização e pelo enriquecimento das relações através do diálogo.

Portanto, os conceitos discutidos nesse capítulo sustentam os próximos passos desta dissertação que parte ao encontro das memórias de infância de velhos moradores da cidade de Tanguá. 


\section{Os velhos moradores de Tanguá: sua relação com a cidade, o trabalho e a vida}

A arte de narrar é uma relação alma olho e mão: assim transforma o narrador sua matéria, a vida humana. (ECLEA BOSI, 2015, p. 90)

Dando continuidade a este estudo é importante situar as condições de produção das entrevistas e fazer uma breve apresentação de cada entrevistado.

As entrevistas foram realizadas nas residências dos entrevistados, onde cada um recebeu a pesquisadora com dias e horários previamente agendados. Estas foram gravadas e transcritas com autorização dos mesmos que assinaram o Termo de Consentimento Livre e Esclarecido. Duraram aproximadamente entre 60 a 120 minutos, somando ao todo uma média de 10 horas de gravação e todas foram transcritas na íntegra pela pesquisadora. Estas transcrições, em sua totalidade, formaram um Relatório de Transcrição de Entrevistas que quando citado nesta dissertação será representado pela sigla RTE.

Nesta pesquisa, transcrever as entrevistas foi uma opção metodológica extremamente significativa, e se constituiu uma prática fundamental paraa construção da noção de que tanto pesquisador quanto pesquisado são sujeitos e objetos numa pesquisa. Um emudece temporariamente para que o outro se exprima. Como explica Bosi (2015, p.18):

...nesta pesquisa fomos ao mesmo tempo sujeito e objeto. Sujeito enquanto indagávamos, procurávamos saber. Objeto enquanto ouvíamos, registrávamos, sendo como que um instrumento de receber e transmitir a memória de alguém, um meio de quem este alguém se valia para transmitir suas lembranças.

A pesquisa procurou, sempre que possível, reduzir o distanciamento com as pessoas com quem tratou. E, muitas vezes, felizmente, foram estabelecidos laços de afetividade, numa relação solidária marcada pela simpatia, que não pode ser confundida com complacência e manipulação. Todo propósito foi voltado para um percurso que busca a aproximação com os sujeitos pesquisados, pois, para a pesquisa ambos, sujeito e objeto, se constituem reciprocamente, alternando entre si as condições de criador e criatura da história que se quer desvendar. Para Oliveira (2011, p.63)

Esta compreensão ajuda a rechaçar atitudes pretensiosas do pesquisador em imaginar que o poder criador dos sujeitos pesquisados só se revela verdadeiramente sob a mediação de suas lentes, de seu olhar, de suas reflexões. 
Diante desta reflexão, surge, então, um caminho alternativo que é pensar em relações de interdependência entre sujeito e objeto, o que significa a impossibilidade de um existir sem o outro. Do lado do sujeito pesquisador não duvidamos o quanto ele depende da adesão sincera e voluntária dos sujeitos pesquisados para ultrapassar apanhados superficiais. Do lado do sujeito pesquisado é por meio do trabalho do pesquisador que este vai ser visto, podendo encontrar um meio pelo qual possa expressar-se e se reconhecer ao mesmo tempo. Escrevendo sobre este processo Oliveira (2011, p.64) esclarece:

Que fique bem claro, porém: o desejável seria que sujeitos sociais prescindissem de outrem para se expressar. Por isso a importância do sujeito pesquisador, penso eu, não incide tanto na sua capacidade de ser ainda capaz de enxergar, ou seja, de ter um discernimento simbólico da situação, mas na realização, em condições adversas, deste discernimento, o que representa convite explícito para que esse ato de ver se pluralize dentro da sociedade.

Nesse sentido, a organização e preparação para ouvir os depoimentos são momentos importantes, já que,nesta pesquisa a entrevista caracteriza-se por um mergulho na vida do entrevistado com a preocupação de estabelecer um diálogo. Para que a entrevista seja um espaço de narrativa se faz necessária uma disposição para ouvir, porque muito mais do que colher informações, o que se pretende é conhecer e compreender o outro. E para que a conversa pudesse fluir, foi necessário ter um roteiro ${ }^{3}$ que servisse de orientação para captar os principais aspectos das memórias de infância, todavia ressalvo que, embora o pesquisador de certa forma conduza a conversa, quem decide o que vai relatar é o narrador.

Narrativa linear e individual dos acontecimentos que nele considera significativos, através dela se delineiam as relações com os membros de seu grupo, de sua profissão, de sua camada social, de sua sociedade global. Que cabe ao pesquisador desvendar (QUEIROZ, 1988, p. 20)

No caso desta pesquisa, é enriquecedor apresentar um breve resumo sobre a história de cada entrevistado e sua relação com a cidade, o trabalho e a vida. Para isso, nomes verdadeiros foram substituídos por outros fictícios com o objetivo de preservar a identidade das pessoas. Nomes trocados não invalidam a pesquisa, não distorcem conteúdos, mas protegem a intimidade dos sujeitos numa cidade tão pequena como Tanguá. É importante ressaltar também que a pesquisa trata os entrevistados de "senhor" e "senhora", forma comumente utilizada na cidade para tratar seus velhos moradores e que expressa ao mesmo tempo carinho e

\footnotetext{
${ }^{3}$ Este roteiro foi apresentado no capitulo 1, página 20.
} 
respeito. Como este trabalho procura se aproximar da realidade dos entrevistados, e da vida da cidade, a pesquisa decide se apropriar desta forma de tratamento para se referir ao velho morador de Tanguá.

Neste capitulo as entrevistas serão apresentadas num recontar de cada história e, neste breve recontar,são apresentadas as relações de cada morador entrevistado com a vida na cidade de Tanguá.

\section{1. "Naquela época criança queria crescer para fazer alguma coisa. Ser adulto para ter liberdade, isso que a gente queria" - Senhora Alzira}

A senhora Alzira tem 94 anos e foi a primeira funcionária da agência dos correios da cidade, trabalho conquistado por indicação de um amigo de seu pai quando ainda tinha 19 anos.

Com seus 94 anos senhora Alzira é uma das moradoras mais antigas da cidade de Tanguá. Nasceu por mãos de parteira e é a filha mais velha de uma família de sete irmãos. Seu pai era proprietário de uma fazenda e possuía uma tropa de burros e cavalos que carregava lenha da serra até a cidade. Anos mais tarde, com a venda da fazenda, tornou-se empregado da Prefeitura de Itaboraí. Senhora Alzira conta que a sua mãe era dona de casa, e foi com ela que aprendeu o ofício de cuidar da casa e dos irmãos mais novos. "Olha, eu comecei a cozinhar subindo em dois tijolos de... no fogão de lenha que eu não dava altura”.

As recordações da infância da senhora Alzira são bem especificas. Recorda que como irmã mais velha, era a que mais trabalhava e tinha muitas responsabilidades. "Eu era a mais velha e a mais velha sempre pega o mais pesado. Torrava café, dava pensão (refeição) para quatro rapazes da usina. Tudo feito na minha infância." Desde muito cedo demonstrava talento para culinária e, quando percebido pelo pai, logo se transformou em mais uma responsabilidade: servir refeições para funcionários da usina.

A culinária surgiu na sua vida desde as brincadeiras de infância, a senhora Alzira contou que brincava de brincadeiras de roda, de casinha, mas gostava mesmo era de brincar de cozinhar. Nesta atividade cozinhava de verdade em fogõezinhos de lenha construídos por ela e suas amigas. E foi no fogão de lenha que assou seu primeiro bolo. Encantada com o talento da filha, a mãe a matriculou num curso para aprender a fazer e a decorar bolos para festas. Durante algum 
tempo conseguiu conciliaras duas atividades, o ofício nos correios e a confecção de bolos para festas.

Aos 19 anos, casou-se com um rapaz que conheceu ainda no tempo em que servia refeições parafuncionários da usina. Permaneceram casados por 50 anos. A casa onde viveu toda sua vida foi comprada pelo seu noivo e por muito tempo serviu de sede dos correios na cidade de Tanguá. Mãe de três filhos homens, a senhora Alzira vivenciou grande parte das mudanças ocorridas na cidade, desde a chegada da primeira Usina até o fechamento da CIBRAN, e ainda afirma que a Tanguá do passado era muito monótona e que a vida de hoje é muito melhor porque "a gente não tinha a liberdade de hoje e não tinha o conhecimento, não tinha instrução”.

\section{2. "Olhava o chão pertinho de mim e perguntava: Quando eu vou ver este chão lá longe?" - Senhor Salim}

O Senhor Salim tem 94 anos e viveu toda a sua vida na cidade de Tanguá. Filho de pai sírio e mãe brasileira, conviveu com uma grande família formada por seis irmãos e quatro irmãs.

Toda a sua história foi marcada por muito trabalho. Recorda que desde muito cedo ajudava sua mãe na lavoura. Seu pai foi proprietário de um armazém em Rio Bonito, município vizinho a Tanguá, e como o armazém não era suficiente para sustentar a casa, ele e seus irmãos ajudavam a mãe nos cuidados com a plantação, de onde vinha a maior parte da alimentação da família, enquanto as irmãs cuidavam da casa. Neste tempo, segundo senhor Salim, as brincadeiras se misturavam com o trabalho. "Nós fazíamos corda de noite, aquela criançada fazia corda, fazia esteira e fazia farinha. Trabalhávamos muito! Na brincadeira, trabalhávamos!” E mesmo com muito trabalho diz que havia tempo para as brincadeiras com os amigos. "Aos domingos nós jogávamos malha e jogávamos também futebol. Domingo era nosso dia de folga". Seu maior desejo era crescer para ver o chão de longe e poder assim realizar as tarefas diárias sem tanto sacrifício e, por este motivo, queria crescer para ser como os adultos.

Em suas lembranças, diz que aprendeu a ler na Cartilha ABC, tendo aulas com um senhor que ensinava a várias crianças da região, pois naquele tempo não havia escola na cidade. "Lá perto de casa, da nossa casa, tinha um senhor com 
nome de Antério Gaspar, antigamente não existia professor aqui. Então como diz o ditado: "em terra de cego quem tem olho é rei.Quem sabia ler botava uma escola em casa para ensinar a gente”. O senhor Salim conta também que as aulas aconteciam ao entardecer, porque o senhor Antério trabalhava na usina durante o dia. Somente anos mais tarde a primeira escola foi organizada na cidade e junto com ela chegou a primeira professora.

"Tanguá não tinha ruas, não existia Tanguá. Tanguá era uma vilazinha”. Esta é a descrição que o senhor Salim faz de Tanguá no passado e a diversão, segundo ele, era andar livre pela cidade fazendo travessuras. "Mas para fazermos nossas travessuras, subir em pé de jamelão, roubar goiaba, roubar manga, isso era nós". Quando tinha apenas 14 anos perdeu o seu pai, tempos difíceis para o senhor Salim, que começou a trabalhar na usina de cana de açúcar na intenção de ajudar a sustentar a família. "Passei a ter um salário e melhorou”. Casou-se aos 26 anos, depois de juntar um "pé de meia" e afirma categoricamente: "Para casar tinha que ser homem de responsabilidade”. Pai de cinco filhos, hoje o senhor Salim está viúvo e fala com um tom de preocupação: "Era muito gostoso antigamente. Agora não tem nada de gostoso não. As crianças de hoje estão perdendo muitas coisas".

\section{3. “A gente não se esquece das coisas" - Senhora Maria Augusta}

A senhora Maria Augusta tem 75 anos, é professora aposentada da Rede Estadual de Educação do Rio de Janeiro e trabalhou no Colégio Estadual Antônio Francisco Leal, primeiro colégio estadual do município.

A senhora Maria Augusta é a filha caçula de uma família com sete irmãos. O seu pai trabalhou na usina de cana de açúcar dirigindo caminhão carregado de cana das plantações para a usina. Recorda que em muitas situações andou na carroceria deste caminhão por ocasião das festividades religiosas. "A gente fazia peregrinação da igreja. Tudo em cima daquele caminhão”. Acredita que por ser filha caçula, teve uma vida mais confortável que seus irmãos mais velhos, que ajudaram mais no trabalho diário da casa e, por este motivo, não tiveram a mesma oportunidade de estudar. Quando concluiu o Ensino Fundamental continuou seus estudos na cidade de Itaboraí fazendo o Curso Normal. Terminado o Curso Normal começou a lecionar na cidade de Itaboraí, para anos mais tarde, ingressar na faculdade de Geografia na cidade de Niterói. Ao concluir a faculdade, fez 
concurso publico e ingressou na rede estadual de ensino começando a lecionar em Tanguá.

Sobre sua infância, Maria Augusta diz

"a minha infância foi uma infância normal como de qualquer pessoa. Não tenho nada que reclamar da minha vida não. Nunca tive dificuldade, meus pais eram pobres, mas sempre tinha o que comer, o que vestir".

Destaca que sempre foi boa filha e boa aluna e se justificou da seguinte forma:

"Nunca apanhei, nunca apanhei. E depois que ingressei na escola, não vou dizer que era a aluna primeiro lugar, mas sempre fui uma aluna aplicada. Eu era representante do pelotão de saúde, que cuidava da limpeza da escola, a gente varria e cuidava da escola".

Sente saudade da cidade do passado e afirma que a vida em Tanguá era muito tranquila. Confessa que, hoje, sente medo até mesmo de ficar em casa. “Antes não era assim, era janela aberta... quando eu vim morar nesta casa era tudo aberto e as casas aqui eram contadas. A gente brincava solto nessas ruas." Neste momento se emociona e conclui

"Quando olho para o passado eu tenho saudade de muita coisa, tenho saudade dos canaviais. Era tudo isso aqui canavial. Sabe o morro da igreja? Não era igreja não! O morro era um laranjal que chamávamos de pomar, tudo laranja! Era tudo lindo!'”

Atualmente Maria Augusta vive com duas irmãs na mesma casa onde cresceu e passou parte de sua infância. Participa ativamente das atividades da igreja católica e gosta de viajar.

\section{4. "Mas a gente era feliz! Isso sem sombra de dúvida nenhuma" - Senhor Rogério}

O senhor Rogério tem 77 anos e somou 30 anos de trabalho no escritório da Usina de açúcar Tanguá e depois na CIBRAN.

Sua família era formada por dois filhos homens e quatro irmãs. Conta com tristeza que seu pai faleceu muito cedo, o que fez com que todos ajudassem no sustento e manutenção da casa. Mas ressalta que, mesmo com todas as dificuldades, seus pais fizeram questão que todos estudassem. 
"Já nessa época nós tivemos este problema que meu pai faleceu, então todo mundo começou a ajudar. E meu pai e minha mãe sempre muito preocupados com a gente com a questão da educação"”.

A mãe era dona de casa e seu pai possuía cavalos e burros que carregavam lenha da serra para a cidade. Recorda-se que nas férias escolares fazia esta viagem com o pai e que gostava muito de ajudar a banhar os animais no rio, porque aproveitava e banhava-se também.

O senhor Rogério e seus irmãos estudaram na escola primária de Tanguá e foram alunos da primeira professora do município,a professora Zulquerina Rios. "Nós estudamos na escola primária de Tanguá e depois, porque aqui não tinha ginásio, fomos estudar em Rio Bonito no Ginásio Rio Bonito”. Da escola primária de Tanguá possui boas recordações:

"E ali foi uma fase muito boa, fase daqueles eventos da parte de educação que a dona Zulquerina gostava muito: os grupos de poesias. E nós saíamos daqui para irmos a outros colégios de Itaboraí, formando aqueles grupos para recitar poesias. Fazíamos apresentações até no Teatro Municipal João Caetano em Itaborai."

Recorda-se de uma infância cheia de dificuldades, mas repleta de felicidade, ele diz: "Mas a gente era feliz, isso sem sombra de dúvida nenhuma! A criançada se juntava com as brincadeiras dentro e fora do colégio". As brincadeiras iam até a noite, principalmente em noites claras. As brincadeiras preferidas eram: "pião, futebol e pipa. A pipa então era uma coisa fantástica!” A solidariedade entre os amigos de infância é recordada com emoção: “Um colega que tinha uma melhor situação emprestava ou comprava e chamava: brinca com o meu, toma é seu!"

O senhor Rogério tem dois filhos e é avô de quatro netos. Diz que sente muito prazer em estar com eles e se encanta com as mudanças atuais. Considera fantástica a internet, que segundo ele, facilita a vida. Mas fica sempre aconselhando os netos, "porque com a internet também vieram muitas coisas ruins”, ele diz. Outra preocupação com a geração de hojeé com o consumo de drogase sobre este tema fala:

"Nós naquela época vivíamos mais em família e não tinha o poder das drogas. A droga é o pior mal que existe! E nós tínhamos esta vantagem de nem se preocupar com as drogas. Hoje você vê, os pais tem que estar sempre atentos. Eu tenho quatro netos e isso me preocupa muito". 
O senhor Rogério considera uma perda que seus netos não possam desfrutar hoje da liberdade que ele desfrutava na sua infância.

Atualmente, o senhor Rogério trabalha na Câmara Municipal de Vereadores de Tanguá, diz que não tem vontade de parar de trabalhar, que ama a cidade onde nasceu e vive até os dias atuais.

\section{5. “Ah! Era uma magia! Tudo muito bonito, muito colorido!'- Senhora Elizete}

A senhora Elizete tem 59 anos e é professora aposentada da Rede Estadual de Educação do Rio de Janeiro. Nasceu em Lagoa Verde, região rural do município de Tanguá, e passou a sua infância na fazenda de seus pais nesta região. Sobre isso ela relata

"Eu passei minha infância em Lagoa Verde. Nasci na mesma casa que meu pai nasceu, a fazenda que era do meu avô, ali eu nasci e fui a sétima filha do casal. Quando nasci meu pai tinha 59 anos e eu fui criada com mimos de neta".

Quando tinha cinco anos começou a frequentar a escola que estava situada na própria fazenda. A escola funcionava em uma casa velha que seu pai e seu tio faziam questão de manter para que os filhos dos colonos aprendessem a ler e a escrever. Elizete ia para a escola acompanhando as irmãs mais velhas que na época eram as professoras da escola. Conta que foi assim que aprendeu a ler muito cedo: "Eu fiquei como ouvinte e quando ela viu eu estava lendo, por isso eu adiantei o estudo e com 17 anos estava na faculdade”.

Com muita emoção, Elizete se recorda da infância dentro e fora da escola. Sobre a escola conta que brincava muito com as outras crianças, que gostava da merenda e não se esquece do uniforme que usava: "saia azul de preguinhas $e$ blusa branca". Fora da escola o que marcou sua infância foi andar a cavalo e os banhos de rio: "Tomar banho de rio que era assim aquela praia. Aquela areia como se fosse uma praia mesmo e aquela água clarinha”.

Concluída a antiga $4{ }^{\mathrm{a}}$ série, Elizete teve que sair da região rural para morar com sua irmã no centro da cidade para assim dar continuidade aos seus estudos no Colégio Estadual Antônio Francisco Leal. Quando concluiu a antiga $8^{\mathrm{a}}$ série do primeiro grau, foi morar em Rio Bonito, município vizinho de Tanguá, com a irmã que havia se casado e assim poder ingressar no $2^{\circ} \mathrm{Grau}$. Seu pai, que tinha 
orgulho de que suas filhas se formarem como professoras, influenciou a escolha de Elizete pelo Curso Normal, que no início da carreira de magistério chegou a dar aulas na escola da fazenda onde estudou.

Lecionava na escola da fazenda pela manhã e fazia Licenciatura em Letras e Literatura a noite em Niterói. Concluída a faculdade prestou concurso público e começou a lecionar Português na rede estadual de ensino. Elizete relata também sobre o tempo em que lecionou no Colégio Cenecista Manoel João Gonçalves, neste período era muito nova e ainda não havia concluído o curso de Letras. "Bons tempos", segundo ela.

Elizete casou-se e tem duas filhas, ainda não tem netos. Diz que seu desejo é que isso aconteça em breve e deseja que seus netos possam ter uma infância de muito carinho, como foi a sua infância.

\title{
4.6. "Brincávamos todo dia! Isso era todo dia!"-Senhor Luiz
}

O senhor Luís tem 65 anos e por muitos anos foi torneiro mecânico na CIBRAN. Começou como aprendiz de torneiro e até hoje se diz apaixonado pela profissão: "Minha paixão pelo torno que é uma coisa fora do comum”. Seu primeiro trabalho foi na fábrica de aguardente Tanguaria ${ }^{4}$.

Quando criança, o senhor Luís estudou na Escola de Tanguá, dirigida pela professora Zulquerina Rios, que anos mais tarde se transferiu para o Colégio Estadual Antônio Francisco Leal. Este colégio foi construído pelo governo do Estado do Rio de Janeiro e sobre este tema relata: "Eu, quando aluno, ajudei a fazer a mudança da escola velha para o colégio novo. Foi uma bagunça boa pra caramba! Carregava gato, cachorro, foi uma brincadeira boa demais!” Para o senhor Luís, a escola era um lugar para além de aprender a ler e a escrever, era um lugar para encontrar os amigos e conviver. Diz que não gostava muito de estudar não, no entanto ia com muito prazer para a escola.

\begin{abstract}
"Na minha época ... Meu Deus! Era muito bom ir para o colégio! A gente ia com prazer para o colégio. A gente não ia estudar não, a gente ia para o colégio participar daquilo, do colégio. Porque de estudar eu nunca fui. Eu era de pular janela, fugir de castigo. Eu fui expulso do colégio umas três vezes. O que eu fiz, eu não lembro, só sei que fui expulso".
\end{abstract}

\footnotetext{
${ }^{4}$ Tanguaria era a cachaça produzida na cidade. Atualmente ela não é mais fabricada, mas segundo os depoimentos, era muito apreciada e conhecida na região.
} 
As brincadeiras na rua eram mais divertidas, segundo ele, do que a rotina cheia de obrigações imposta pela escola. "Brincávamos todo dia! Isso era todo dia!”. Brincavam até de brincadeira que eles mesmos inventavam. Depois da escola, no horário da manhã a maior ocupação era brincar. Brincar na praça da cidade, chupar laranjas colhidas nos laranjais, chupar cana, jogar futebol, tomar banho de rio e ir à casa dos amigos e da avó materna. O senhor Luís recorda com emoção: “Liberdade! Naquele tempo a gente tinha liberdade! Você podia ir para a beira do rio tomar banho, e se o canavial pegasse fogo a gente ia caçar preá. Era a liberdade que a gente tinha”.

Viúvo, pai de três filhas e avô de cinco netos, atualmente o senhor Luís está aposentado e dedica o seu tempo convivendo com a família e cuidando de suas coleções . Coleção de latas de cerveja, lápis, moedas, fotos e objetos antigos. Um robby que pratica com muito cuidado e dedicação. Como considera o torno mecânico uma paixão e um ofício do qual sente falta, seu próximo projeto é montar uma oficina em casa para voltar a fabricar e consertar peças.

Estas histórias sãosingulares, histórias queora se aproximam ora se afastam e trazem em si muito de como era a vida na cidade e a relação da infância com a mesma. Expressões individuais que descortinam a vida coletiva na cidade de Tanguá e nos apresentam um passado rico e fecundo, um passado que não deveria morrer com cada uma dessas pessoas. Passado que é cultura, como descreve Oliveira (2011, p.36) "cultura como vida pensada". Os depoimentos são "vidas pensadas" um legado de gerações precedentes que foram produzidos no interior das relações sociais e que possuem o potencial de promover em nós a humanidade tão desejada em tempos de barbárie.

Conhecendo um pouco melhor cada entrevistado, no próximo capítulo mergulharemos nas memórias de infância. Com elas percorreremos um caminho ao encontro de histórias que não foram contadas, visitaremos tempos perdidos que só o trabalho com a memória pode nos dar o prazer de desfrutar.Segundo Benjamin (2012, p.242) este encontro secreto já estava marcado:

Se assim é, então existe um encontro secreto marcado entre as gerações precedentes e a nossa. Então, alguém na terra esteve à nossa espera. Se assim é, foi-nos concedida, como cada geração anterior à nossa, uma frágil força messiânica para qual o passado dirige um apelo. (p.242)

Encontro marcado e necessário para que o passado possa sair das sombras do esquecimento e a história possa seguir seu percurso sob as luzes da esperança. 


\section{Memórias de infância em Tanguá}

Se o adulto não dispõe de tempo ou desejo para reconstruir a infância, o velho se curva sobre ela como os gregos sobre a idade de ouro. (ECLEA BOSI, 2015, p.83)

No capítulo anterior foram apresentados os entrevistados e sua relação com a vida e com a cidade. Neste capitulo,as memórias de infância são apresentadas em depoimentos que foram organizados por gerações e por gênero. A opção por esta organização tem como objetivo dar maior visibilidade as mudanças que foram acontecendo na cidade, na vida dos moradores e consequentemente na infância que estava inserida naquele contexto. Período que ficou marcado pela chegada da usina de cana-de-açúcar, de novos meios de transporte e da energia elétrica, como também pela a construção de novas estradas, e pela organização da primeira escola da cidade.

O progresso chegou à cidade de Tanguá com a ideia de que se tratava de "um processo ascendente da humanidade, onde a capacidade, os conhecimentos e a perfectibilidade humana seguiriam uma trajetória em flecha e em espiral." (BENJAMIN, 2012, p. 249). Com o progresso vários aspectos da vida mudaram, no entanto, Benjamin (2012) nos alerta para a possibilidade da humanidade se perder dentro daquilo que é considerado como um avanço, de se perder dentro de um tempo "vazio e homogêneo" (BENJAMIN, 2012, p.249).

A organização das memórias de infância por gerações e gênero se posiciona contra esse tempo "vazio e homogêneo" que o progresso impôs à vida na cidade. As memórias aqui apresentadas são tempos especiais, "tempos de agora" (BENJAMIN, 2012) repletos de sentido que enriquecem a experiência do viver.

Todos os entrevistados moram em diferentes bairros, mas muito próximos um do outro. As habitações variam das mais modestas e simples àquelas de alvenaria com mais recursos e conforto, caracterizando construções mais recentes e modernas. As residências possuem um clima aconchegante,que é mostrado na disposição dos móveis, na arrumação dos quadros e das fotografias, do cheiro que exala dos alimentos preparados na cozinha. Todas as entrevistas, com exceção de uma que foi realizada na cozinha, foram realizadas na sala da casa. Ao entrar nas salas a multiplicidade de objetos impressionam. A televisão ocupa um lugar de destaque, acompanhada pelos bibelôs na estante, chamam atenção também os quadros e as fotografias. São comuns os quadros inspirados em cenas bíblicas, 
como a da Arca de Noé e imagens de santos em pequenos altares. As fotografias trazem registros de momentos em família ou lembram familiares até os que já faleceram.

Neste ambiente, foram realizadas as entrevistas e com o decorrer das visitas e das observações surgiram sensações tão variadas que só o convívio humano é capaz de suscitar. Os olhos e os ouvidos atentos ajudam muito, porém os ensinamentos parecem não ter fim. Assim, ao final deste capítulo serão apresentadas as categorias que emergiram das memórias de infância dos velhos moradores da cidade.

\subsection{Memórias da Senhora Alzira e do Senhor Salim - "Desde que eu me entendia por gente, eu ajudava a minha mãe"}

A senhora Alzira e o senhor Salim nasceram no ano de 1922 e compartilham memórias bem próximas da cidade. Viveram num tempo de muita escassez, onde tudo era muito difícil. O senhor Salim mora na mesma casa onde nasceu e a senhora Alzira mora na casa que seu falecido esposo comprou quando se casaram. As casas são ambientes cheios de recordações, tudo possui um significado especial. A partir da casa que a vida se amplia e se estende para a cidade. A casa da infância foi especialmente citada como o primeiro espaço social. A casa com seu quintal que se expandia para as ruas, para as outras casas e a para paisagem natural. A partir da casa, irradiava-se a vida para o mundo.

\footnotetext{
"Minha casa era uma casa de metade de tijolo e a outra metade de pau-a-pique com aqueles bambus e chão batido, pois não tinha cimento não. Minha casa tinha três quartos, uma sala, corredor, cozinha e não existia banheiro, porque antigamente não existia banheiro. $O$ banho a gente tomava num lugar reservado e só usava pinico. Mas o pinico a gente só usava quando estava doente, o resto fazia lá fora mesmo. As meninas que sofriam, porque usavam e tinham que lavar depois" ( Senhor Salim, RTE, 2016, p.53).

"Era de pau-a-pique. Tinha três quartos e duas salas, uma cozinha e uma dispensa. Antigamente chamava-se dispensa de quartinho de dispensa. Tinha luz de motor, porque nessa época não havia eletricidade e meu pai nunca deixava faltar gasolina no motor dele" (Senhora Alzira, RTE, 2016,p.29).
} 
A casa apresentou-se não como um lugar imaculado, mas como primeiro espaço de convívio, onde sentimentos e sentidos começavam a produzir subjetividades.

\begin{abstract}
"Meu pai não era mau, ele era muito bravo! Porque quando ele chegava em casa ele entrava pela porta da frente e a gente saía pelos fundos no quintal e procurava alguma coisa para fazer. Ele era bravo mesmo!" (Senhora Alzira, RTE, 2016,p.30).

"À noite nós ficávamos do lado de fora e tinha uns bancos. A gente fazia uns bancos, papai fincava aqueles esteios de pau na beira das paredes e botava aquelas tábuas e apertava, a gente ficava sentado ali ouvindo histórias. Às vezes, papai contava histórias do país dele e ele falava diferente e quase a gente não guardava as coisas que ele falava. Ele se comunicava com a gente, falava português muito bem, mas para contar histórias da terra dele... ele já ia contar histórias com aquele idioma de lá" (Senhor Salim, RTE, 2016 p. 54 e 55).
\end{abstract}

Da casa, a cidade crescia em todas as direções, com a natureza sempre presente. A cidade, também surgiu nas lembranças. Sempre enriquecida pelas relações sociais nela construídas:
"Tanguá não tinha ruas, não existia Tanguá. Tanguá era uma vilazinha, era aquilo ali, não tinha Tanguá ali. Não tinha aquela rua era tudo mato. Aonde é a loja do Senhor Manoel Pinto ali tinha uma árvore enorme e não havia aquelas casas ao redor não. Tinha somente o correio e o cartório e onde é o mercado era uma venda. A estrada para Campos passava aqui por dentro, eu andava tudo isso ai, e só depois fizeram a estrada de cima onde se passa hoje" (Senhor Salim, RTE, 2016, p.52 e 53).
"Tanguá era um lugar muito monótono, não tinha diversão nenhuma. Quase só os bailezinhos na Pensão de Dona Olga, as Domingueiras, e os jogos de futebol" (Senhora Alzira, RTE, 2016, p.33).

Segundo os relatos do senhor Salim e da senhora Alzira a escola demorou anos para chegar a cidade, enquanto isso:
“... perto da nossa casa tinha um senhor como o nome Antério Gaspar. E antigamente aqui não tinha professor, a primeira professora veio depois, a Dona Zulquerina Rios. Então como não havia, como diz o ditado: " na terra de cego que tem olho é rei”, quem sabia ler botava uma escola em casa para ensinar a gente" (Senhor Salim, RTE, 2016, p.49).

Tanto o senhor Salim quanto a senhora Alzira frequentaram essas aulas na casa do senhor Antério, e segundo os seus relatos, o ensino era fragmentado e não permitia às crianças encontrarem sentido nas atividades. Numa linha 
tradicional e ao mesmo tempo informal, o ensino era assim representado: o conhecimento docente era medido pela autoridade, o professor era aquele que sabia o conteúdo e os alunos aqueles que deveriam aprender. Isso acontecia através de um jogo subliminar onde os primeiros fingiam ensinar e os últimos se esforçavam para aprender ou fingiam que aprendiam:

“... eu tinha um amigo inteligente que não se incomodava de dar cola para gente. Então eu apanhava cola com ele e tudo bem. Quando ela não dava a cola eu somava e tudo certo, porque o professor não ia fazer a conta novamente. Mas quando era a esposa do professor, ela conferia tudinho. A primeira conta não deu certo, a segunda e a terceira, ela me botou de castigo e eu fiquei envergonhada. Já pensou uma moça como eu não saber fazer contas? Quando ela me mandou ir para o castigo no banheiro eu fui lá e arranquei a cebolinha da horta dela. Foi pior, eu fiquei depois da hora refazendo tudo" (Senhora Alzira, RTE, 2016, p.30).

Neste contexto a infância aparece envolta num ambiente opressor, tanto em casa quanto na escola e a palavra do adulto era a palavra final. Infância vivida entre as contradições do mundo adulto, uma infância marcada pelo trabalho dentro da esfera familiar, o que certamente produziu visões similares da infância, como revelam os narradores:

"Desde que eu me entendia por gente, eu ajudava a minha mãe. Olha, eu comecei a cozinhar subindo em dois tijolos, porque não dava altura no fogão de lenha. Eu era a mais velha e a mais velha pegava sempre no pesado. Torrava café, dava pensão para quatro rapazes de Usina Tanguá, lavava muita roupa. Tudo isso feito na minha infância" (Senhora Alzira, RTE, 2016, p. 28).

"Aqui na casa do senhor Casimiro tinha uma casa de farinha, então a gente à noite corria para fazer farinha e polvilho. Dali fazia beiju, tapioca e depois íamos sentar e comer" (Senhor Salim, RTE, 2016, p. 46).

Desde muito cedo, as crianças estavam inseridas no trabalho familiar. Ajudar no sustento da família era condição de sobrevivência. Cada criança representava parte da mão de obra, dentro e fora da família.

"Nós cuidávamos da lavoura. Meu pai trabalhava na usina depois ele passou para a Empresa Agrícola Fluminense e eu já ajudava a puxar burro carregado de goiaba. Mamãe trabalha na lavoura como o pessoal e plantava tudo. A gente vivia do que ela plantava e do salário de papai na empresa. Ele trabalhava uma época na empresa e outra na lavoura, vigiando a lavoura" (Senhor Salim, RTE, 2016, p.54). 
"Quando mocinha costurava até tarde da noite, até uma hora da manhã, com lamparina e querosene. Foi ai que escangalhei minha vista. Mas dinheiro não via não, meu pai apanhava tudo!" (Senhora Alzira, RTE, 2016, p.37).

Esta realidade revelada pelos entrevistados se mostrou complexa e não linear. Ao mesmo tempo em que o excesso de responsabilidade na tenra idade foi destacado, tempo de brincar em meio ao trabalho também foi apontado. Como conta o senhor Salim: “Trabalhava, trabalhava brincando. Nós fazíamos corda de noite. Aquela criançada fazia corda, fazia esteira e fazia farinha"(Senhor Salim, RTE, 2016, p.46). A senhora Alzira conta sua experiência:

\begin{abstract}
"Eu via as pessoas de fora fazendo bolo e tinha a maior vontade de fazer. Então apanhei uma receita, mas não tinha forma, não tinha onde pedir, não tinha onde comprar, não tinha essas coisas. Peguei uma lata de banha de dois litros, peguei a receita e comprei as coisas. Nessa, minha mãe me ajudou com boa vontade e aí eu fiz um bolo. Bati o bolo, botei no fogão de lenha fechado com aquelas placas de ferro. Então fiz o bolo, botei fogo ali, deixei esquentar bem com bastante brasa até o final. O bolo saiu uma beleza! Quando o meu pai chegou, minha mãe toda entusiasmada mostrou a ele e meu pai ficou admirado. Ele falou que ia mandar fazer um fogão para mim do lado de fora na varanda da casa. Ele mandou fazer, na parede mesmo, um fogão de barro direitinho. Comecei a fazer bolos." (Senhora Alzira, RTE, 2016, p. 37)
\end{abstract}

Neste contexto, as brincadeiras revelavam a interação que as crianças possuíam com o mundo. Brincavam de comidinha, mas cozinhavam "de verdade”, brincavam de colher goiabas, fazer corda, fazer farinha, isso imitando o trabalho dos adultos. Trabalho no qual estavam totalmente inseridos.

Com a capacidade de subverter a ordem (KRAMER, 2002), brincavam de cantigas de roda, jogos e outras brincadeiras. Nesta cantiga de roda o Senhor Salim demonstra a riqueza e singularidade das brincadeiras da época ao cantar uma música:

"Ah! Que rochedo tão alto

Que ninguém pode alcançar

Sentou-se a pobre viúva, sentou-se e pôs se a chorar.

Pergunte a senhora viúva

Com quem ela quer se casar

Se é com o filho do conde ou com o senhor general, general

Não é com nenhum desses moços

Que eles não são para mim

Eu sou uma pobre viúva

Triste e coitada de mim. 


\begin{abstract}
Morreu meu marido no meio das flores
Acabou-se alegria e se acabou o amor

Cobrimos de luto e luto fechado

Semanas inteiras eu tenho chorado."

(Senhor Salim, RTE, 2016, p.64)
\end{abstract}

As memórias de infância do senhor Salim e da senhora Alzira nos revelam uma relação intensa com a vida cotidiana na cidade. Profundamente ligados ao trabalho dentro e fora da casa, a infância de ambos foi marcada por sentimentos ambíguos de amor, rejeição e distanciamento. Sentimentos múltiplos aparecem desnaturalizando papéis previamente estabelecidos de uma infância feliz e revelando faces surpreendentes dos seres humanos e do que foi ser criança em Tanguá naquela época.

"Naquela época, criança queria crescer para fazer alguma coisa. Ser adulto para ter liberdade. Isso que a gente queria" (Senhora Alzira, RTE, 2016, p. 31).

"Ser adulto para poder viver minha vida, fazer as coisas sem sacrifício. Eu estava crescendo e ia no armazém fazer compras e botava o saco de compras no ombro e abaixava a cabeça para ir para casa, olhava o chão pertinho de mim $e$ perguntava: quando vou ver este chão lá longe?" (Senhor Salim, RTE, 2016, p.57).

Estas falas revelam uma vida infantil singular. Totalmente integrada à vida, as crianças como o senhor Salim e senhora Alzira não possuíam ilusões sobre a mesma e, em meio às adversidades, brincavam e lançavam esperanças para um tempo futuro: ser adulto. Sabiam, desde a mais tenra idade, das dificuldades cotidianas, pois estavam imersos nelas e delas se alimentavam todos os dias. No entanto, em meio a tudo isso, não deixaram de estabelecer o seu lugar, brincavam, eram criativos e faziam do trabalho uma brincadeira. Mesmo que, intuitivamente, soubessem que como crianças não tinham voz e nem vez fora dos padrões estabelecidos pelos adultos.

\begin{abstract}
"A gente sente muita saudade! Muita saudade! Dá vontade de voltar. Se eu pudesse eu fazia tudo de novo. Eu acho que ia fazer algumas coisas diferentes, não é? Porque a gente quando está nova, você vê e não liga, mas depois que a gente chega a uma certa idade, é que se dá valor a essas coisas que passou, né?" (Senhora Alzira, RTE, 2016, p.42).
\end{abstract}

Imagens de um passado que nos são reveladas através das memórias de infância de velhos moradores da cidade de Tanguá. E qual é a função da 
memória? Nas palavras de Bosi: “Ao fazer cair a barreira que separa o presente do passado, lança uma ponte entre o mundo dos vivos e o além, ao qual retorna tudo o que deixou à luz do sol” $(2015$, p.89).

Então seguimos adiante colocando, através da memória, o passado sob a luz do sol, para podermos dela desfrutar em busca de uma humanização do presente e do futuro.

\subsection{Memórias da Senhora Maria Augusta e do Senhor Rogério - "Minha infância foi muito boa!"}

A senhora Maria Augusta e o senhor Rogério nasceram reciprocamente nos anos de 1941 e 1939. Frutos de uma mesma geraçãopossuem lembranças que revelam uma cidade em transformação. A Usina Tanguá, neste tempo,deixava de produzir apenas doce e melado e entrava no mercado de produção de açúcar e álcool. A paisagem natural se modificou com os grandes canaviais avançando pela cidade, era o progresso transformando a paisagem da cidade, imprimindo um novo ritmo à vida. A senhora Maria Augusta recorda-se da paisagem da época:

"Quando eu olho para o passado eu tenho saudade dos
canaviais! Era tudo isso aqui canavial. Sabe o morro da
igreja? Não era igreja não. O morro era um laranjal que a
gente chamava de pomar. Tudo laranja. Era lindo também! E
para cá, só cana" (Senhora Maria Augusta, RTE, 2016, p.6).

Como podemos perceber, o progresso modificou não apenas a paisagem natural, como também o ritmo de vida que passou a ganhar novos contornos, pois os moradores da cidade passaram a organizar o tempo em função do funcionamento da usina. Ciclos de plantação, colheita e moagem para a produção de açúcar e álcool começaram a gerenciaro cotidiano de todos.O senhor Rogério conta como era esse novo cotidiano implantado pelo progresso:

\footnotetext{
"Tinha seis meses que a usina ficava parada e seis meses que ela produzia. Em maio começava a moagem da cana. Então o que acontecia? No dia $1^{\circ}$ de maio, dia de São José Operário, a gente fazia uma missa e daí começava: maio, junho, julho, agosto, setembro e outubro. Seis meses a usina estava moendo a cana para fazer álcool e açúcar" (Senhor Rogério, RTE, 2016, p.7).
}

Mesmo com o ritmo de vida que aos poucos foi tomando novos contornos, a casa materna apareceu como uma importante referência dos tempos de infância. A casa aparece como um importante lugar de convivência, aconchego e afeto. Nos 
relatos do senhor Rogério e da senhora Maria Augusta, a casa aparece como cenário para uma série de acontecimentos significativos da infância. Como diz Bosi (2015, p. 425) “a história da família é fascinante para a criança”.

"Era bem modesta minha casa. Tinha motor para gerar luz e depois das 10 horas todos iam dormir. Tinha portas e janelas de madeira, cozinha com fogareiro de lenha e era sem muros. Tinha uma mistura entre rua e quintal. Eu dormia sozinha, porque minhas irmãs já haviam se casado" (Senhora Maria Augusta, RTE, 2016, p.7).

"Minha casa era simples, e ficava do lado da antiga igreja católica que foi demolida. Eu me lembro que eu bem criança ainda, o Padre Hugo chegava lá em casa de manhã. Então ela chegava lá em casa e dizia: Dona Rosa, o café! Ele chegava cedo, em dia de missa ou quando vinha fazer alguma coisa aqui. E nesse dia ela chegou e estava na mesa tomando café e eu apareci na sala e falei: Bom dia! E ele falou: Deus te abençoe! Eu saí disparado. Porque naquela época havia muito respeito pelo padre. O padre era uma autoridade fantástica. Minha mãe, com toda aquela idade, pedia a benção ao padre" (Senhor Rogério, RTE, 2016, p. 17).

Nos tempos de meninice, a casa é o centro geométrico do mundo (BOSI, 2015). Mesmo que não seja a primeira casa que conhecemos, mas é aquela em que vivemos os momentos mais importantes da infância. Com olhos de criança seu espaço parece bem maior e as possibilidades de exploração infinitas:

O espaço da primeira infância pode não transpor os limites da casa materna, do quintal, de um pedaço de rua, de bairro. Seu espaço nos parece enorme cheio de possibilidades de aventura. A janela que dá para um estreito canteiro abre-se para um jardim de sonho, o vão embaixo da escada é uma caverna para os dias de chuva. (BOSI, 2015, p.435).

Com o passar do tempo outro lugar ganha significativo espaço na memória dos moradores: a escola. São muitas as histórias e as recordações sobre a primeira escola da cidade, a Escola da Professora Zulquerina Rios. Diferente da geração anterior, os entrevistados relatam que os seus pais incentivavam os estudos e viam que, através dele, seus filhos poderiam ter uma vida melhor. Os relatos revelam que ajudar nas tarefas da casa era necessário, mas o tempo para os estudos começa a despontar como uma preocupação nas famílias.

"Já nessa época nós tivemos esse problema que meu pai faleceu, então todo mundo começou a ajudar. E meu pai e minha mãe eram muito preocupados com a gente e com a questão da educação. Estudamos aqui na escola primária em Tanguá e depois passamos, porque aqui não tinha ginásio, a estudar em Rio Bonito" (Senhor Rogério, RTE, 2016, p. 11). 


\begin{abstract}
"Não tenho o que reclamar quanto a minha vida não, nunca passei dificuldade. Meus pais eram pobres, mas sempre tinha o que comer e o que vestir. A gente tinha o horário da escola, então nessa época eu não trabalhava, mas ajudava. Sempre fui assim é... paparicada, porque era a mais nova. Eu era a caçula $e$ tinha um relacionamento muito bom com meus pais" (Senhora Maria Augusta, RTE, 2016, p.1).
\end{abstract}

O tempo de ir para a escola aparece como um tempo precioso, segundo os entrevistados, "um tempo bom". Tempo de encontrar com os amigos, tempo de brincar e tempo de se sentirem valorizados apesar de toda a rigidez que caracterizava o ensino da época.

\begin{abstract}
"Eu gostava muito da escola! Eu me dedicava muito na escola. Naquela época tinha o pelotão da saúde, então a gente cuidava da limpeza da escola. Participava muito das coisas! Chefiava o pelotão de saúde e andava com aquela fitinha vermelha na blusa. Varria a escola e cuidava da escola. Ah! Eu falava poesias! Poesias era comigo e com Ari. A gente falava poesias e levavam a gente lá para Itaboraí para falar para os políticos. Dona Zulquerina, a diretora da escola, gostava muito disso!" (Senhora Maria Augusta, RTE, 2016, p. 5).

"Existia naquela época a questão da higiene e isso era todo sábado. A gente ia para a escola para a professora corrigir para ver se a gente estava com as unhas e cabelos cortados $e$ limpos. Era assim... dava um trabalho muito grande para as mães, mas tinha isso no colégio" (Senhor Rogério, RTE, 2016, p. 14).
\end{abstract}

Ao começar sair de casa para ir para escola, conviver com outras crianças e recitar poesias em festividades, a infância de Tanguá começa a conquistar um novo lugar dentro da convivência social. Sobre este aspecto, é importante destacar o brincar, que desponta como algo extremamente significativo na vida das crianças, o brincar aparece na geração anterior, mas nesta geração começa a despontar o tempo para brincar.

"E ali tinham as brincadeiras do recreio e como a escola ficava perto do campo de futebol, nós meninos jogámos bola no campo, a própria professora levava. Tinha também pião e pique, só não podia levar pipa para a escola" ( Senhor Rogério, RTE, 2016, p.13).

Brincar dentro e fora da escola, sempre havia um tempo para brincar depois da aula e das tarefas domésticas.Eram muitas as brincadeiras onde a criatividade e a solidariedade infantil organizavam tempos e espaços de ludicidade e alegria. Meninos e meninas brincavam separados e de brincadeiras diferentes. 


\begin{abstract}
"A brincadeira maior que tinha era o futebol que a gente fazia ... era um jogo com bola de pano. Essa bola era feita de pano com meia. A gente pegava aquelas meias grandes, dobrava e enchia de panos e retalhos e transformava numa bola de pano. Ali que começava todo mundo a brincar! Era muita dificuldade e a gente fazia aquelas bolas para jogar. A nossa diversão era o futebol, o pião e a pipa. Um colega que tinha uma melhor situação emprestava, comprava e chamava: toma, brinca com o meu, ou é teu!" (Senhor Rogério, RTE, 2016, p.15).
\end{abstract}

"Brincava de casinha, de queimado, essas brincadeiras assim, de pique. Pique era a coisa mais normal que a gente brincava. A gente ia para casa das nossas primas em Lagoa Verde que era um lugarejo aqui" ( Senhora Maria Augusta, 2016, p.2).

Em muitos casos trabalhar era brincar. Assim como na geração anterior, o trabalho continua fazendo parte do cotidiano infantil. Através do trabalho as crianças desenvolviam a relação de pertencimento familiar. Neste contexto, enquanto os meninos ganhavam o espaço das ruas, as meninas brincavam sob o olhar atento dos familiares nas casas das primas e das amigas. Como conta a senhora Maria Augusta:

"Eu brincava muito com minhas primas! Eu também gostava muito de limpar o quintal! Papai sempre tinha uma plantação em volta da casa e eu tinha a minha enxada, eu trabalhava, eu capinava junto com ele. Isso quando eu era bem nova" (Senhora Maria Augusta, RTE, 2016, p.3).

Em meio as memórias de infância, o tempo social absorve e divide o tempo individual. O tempo social se aproxima do tempo individual, todavia os dois não correm na mesma velocidade. Cada geração, cada indivíduo tem pontos da cidade demarcam sua história. A memória seleciona marcos, pontos de encontro entre o social e o individual:

Chama-nos a atenção com igual força a sucessão de etapas na memória que é toda dividida por marcos, pontos onde a significação da vida se concentra: mudança de casa ou de lugar, morte de um parente, formatura, casamento, empregos, festas. (BOSI, 2015, p. 415).

Configurando marcos da memória, como afirma Bosi (2015) na citação acima, os entrevistados recordaram-se do trágico acidente ocorrido com o Trem Noturno. Este trem era nomeado assim justamente porque fazia a viagem entre as cidades de Niterói e Campos de Goitacazes no período da noite, parando em Tanguá por volta das oito horas da noite.

"Quando o trem parava na estação de Tanguá embarcavam e desembarcavam passageiros e neste dia o trem estava cheio. Chovia muito, o rio transbordou e derrubou a ponte, o trem 
passou logo em seguida matando um número grande de pessoas. Lembro como se fosse hoje, os corpos todos enfileirados esperando para serem retirados" (Senhor Rogério, RTE, 2016, p.26).

"Lembrodo acidente com o trem. O rio encheu e derrubou a ponte e o trem que estava indo para Campos descarrilhou. A gente ficou numa tristeza só!" (Senhora Maria Augusta, RTE, 2016, p.8).

Nesta corrente de lembranças estão guardados episódios notáveis e por vezes cômicos do cotidiano da vida infantil:

"Naquela época tinha uma coisa chamada purgante, aquilo era horrivel! Porque aqui tinha muito aquelas coisas de verme, porque a gente brincava muito no quintal com os pés no chão. E por causa disso, tinha que tomar de vezem quando um purgante horrível. Nenhuma criança gostava. Eu só gostava porque mamãe dizia: toma porque daqui a pouco você vai ter a canja de galinha. Então ela fazia aquela canja gostosa e a gente se animava para tomar o purgante. Essa era uma coisa horrivel que a gente tinha naquela época!"'Senhor Rogério, RTE, 2016, p. 21).

As recordações de infância do senhor Rogério e da senhora Maria Augusta revelam que uma nova fase para a infância de Tanguá começa a nascer. Ainda com marcas da geração anterior, que estava totalmente envolvida no sustento da casa, esta nova geração continua a ajudar a família, mas com a chegada da escola, surgem novas possibilidades. Os pais começam a se preocupar com a formação das crianças, o tempo para ir a escola passa a ser valorizado. As crianças começam a descobrir na escola o mundo da leitura e da escrita, o que certamente influenciou o imaginário infantil.

O tempo de dificuldades e escassez continuou, mas as crianças juntas no espaço escolar e no espaço das ruas começaram a elaborar formas criativas para se integrarem à cidade. $\mathrm{O}$ futebol com bola de meia representa a característica que as crianças possuem de transpor as dificuldades e participar ativamente da vida. Assim, podemos ver uma infância com inteira submissão ao mundo adulto, todavia com um pouco mais de fantasia e liberdade em busca do seu direito à vida na cidade. 


\title{
5.3. Memórias da Senhora Elizete e do Senhor Luís - " Liberdade! Naquele tempo a gente tinha liberdade!"
}

A senhora Elizete e o senhor Luís viveram suas infâncias numa Tanguá onde o progresso se intensificou e o maior marco deste processo foi a chegada do cinema e da televisão à cidade. Contemporâneos de um período onde a usina Tanguá estava sob o comando da família Gonçalvesvivenciaram mudanças que foram marcos na vida de toda a população. A senhora Elizete passou sua infância em uma fazenda no interior da cidade, em uma localidade chamada Lagoa Verde. E o senhor Luís morou no centro da cidade, perto da praça central. E ambos frequentaram a escola desde seus seis anos de idade e dela possuem muitas recordações:

\footnotetext{
"Minha escola era a escola de Dona Zulquerina. O colégio era ali atrás do coreto. E eu, quando aluno, ajudei a fazer a mudança para a escola nova. Foi uma bagunça boa pra caramba! Carregava cachorro, carregava gato! Foi uma brincadeira divertida!"(Senhor Luís, RTE, 2016, p.76).
}

A rotina da escola era marcada por rituais e muitas regras. Existia o momento de cantar os hinos, "com ordem e respeito", lembram os moradores. E havia os castigos e as punições que despertavam medo nos alunos.

\begin{abstract}
"Para entrar no colégio organizava duas filas e cantava o Hino Nacional". Tinha um caderno de hinos: Hinos da Bandeira, da Proclamação da República, eram vários hinos. Se um fizesse uma brincadeira na hora do hino, Dona Zulquerina mandava repetir tudo outra vez. Só entrava para sala de aula,depois que cantava tudo do jeito que ela queria, com respeito $e$ organizado. Não dava para sair fora não. Ela muito exigente demais!" (Senhor Luís, RTE, 2016, p.77).
\end{abstract}

A Senhora Elizete frequentou uma escola na região rural do município. Filha de fazendeiro, estudou na escola que seu pai ajudou a organizar dentro da propriedade de seus familiares. Filha caçula foi alfabetizada por suas irmãs mais velhas, que estudaram em cidades vizinhas.

"E ali eu estudei. E como a escola era próxima a fazenda, era no sítio do meu tio e era minha família que dava aula na escola. Minhas irmãs mais velhas é que eram as professoras e minha irmã Tereza foi quem me alfabetizou. Devido as minhas irmãs irem para a escola trabalhar me levaram para a escola sem eu estar matriculada, e com isso eu aprendi antes como uma ouvinte" (Senhora Elizete, RTE, 2016, p. 69). 
Sua experiência como aluna de uma escola rural possui pontos em comum com a experiência de ser aluno na escola que ficava no centro de Tanguá

"Eu lembro que todo dia, eu sempre estudei na parte da manhã, chegava e tinha que cantar o hino todos enfileirados e depois ia para a sala. Me lembro também da elegância que íamos para a escola... o uniforme era aquela saia de preguinhas com aquele botão, porque a saia caía, né? Miudinha, correndo... Tinha uns botõezinhos e na frente um laço que tinha que ser bem feito e bonito. Minhas irmãs e minha mãe é que me enfeitavam." ( Senhora Elizete, RTE, 2016, p.69)

Tanto a escola que ficava localizada no centro da cidade, como a escola localizada na região rural, possuía uma educação com características rígidas. Mesmo com toda a rigidez, a escola aparece nas memórias de amboscomo um lugar especial e muito apreciado:

"Eu gostava muito da escola! Porque ela ficava numa casa velha no meio do laranjal. Lá as crianças subiam em árvores: nas jabuticabeiras, nas laranjeiras e mangueiras que ficavam perto da escola" (Senhora Elizete, RTE, 2016, p.70).

"Na minha época... Meu Deus era muito bom ir para o colégio! A gente ia com prazer para o colégio. A gente não ia para estudar não, a gente ia para o colégio para participar daquilo do colégio. Porque de estudar eu nunca fui não" ( Senhor Luis, RTE, 2016, p.78).

\section{Como diz Corsaro (2011 p.129):}

Escola, lugar não só de aprender o conteúdo, lugar de convivência, lugar das brincadeiras e das interações, lugar de relações de humanização e de valorização.Na escola as atividades das crianças com seus pares e sua produção coletiva de uma série de culturas de pares são tão importantes quanto sua interação com os adultos. Além disso, alguns elementos da Cultura de Pares afetam as rotinas entre adultos e crianças na família e em outros ambientes.

Este fato aparece nos relatos que se seguem, onde podemos verificar que a espontaneidade infantil abre portas para uma relação mais afetuosa entre professor e aluno.

"Uma vez a professora chegou e falou: Pessoal hoje eu vou ter que sair mais cedo, vou a Niterói no médico. Vocês querem que eu traga alguma coisa para vocês? Eu muito sem vergonha levantei a mão e falei: Eu quero que a senhora traga um carrinho para mim. E ai ela foi embora. Você acredita que no outro dia ela trouxe um carrinho para mim? Eu me lembro até da cor, era um automóvel azul. Quando ela chegou ela me perguntou: Luís, você lembra do que você me pediu ontem? Toma aqui o seu carrinho. Aquilo foi uma farra que eu fiz durante muitos dias. Amarrava aquele carrinho no barbante e andava a escola toda com ele" (Senhor Luís, RTE, 2016, p.78). 


\begin{abstract}
"Só que aí a escola foi ficando velhinha e caindo. Meu tio doou um terreno para o Estado construir uma nova escola. No dia da inauguração eu fiz um discurso". O governador foi, era o senhor Alberto Torres, e papai ficou" todo prosa" porque a filha fazendo um discurso. E eu nem fiquei nervosa, porque criança... eu nem sabia quem era o governador, sabia que era uma festa" (Senhora Elizabete, RTE, 2016, p. 70).
\end{abstract}

O senhor Luís possuía uma relação peculiar com a escola, para ele um lugar de travessuras e de encontro com os amigos. A escola ainda era muito rígida, os castigos e as punições eram muito presentes, segundo ele, castigo na escola, era castigo em casa também.

"Nunca foi meu forte estudar, não. Eu era de pular janela, fugir de castigo. Eu fui expulso do colégio umas três vezes! Mas tinha uma coisa, castigo no colégio, castigo em casa. Se levasse castigo no colégio, mandava avisar seus pais e era castigo em casa era outro castigo ou uma"surrazinha" boa. Não era brincadeira não!" ( Senhor Luis, RTE, 2016, p. 77).

Com menos obrigações na rotina familiar, as crianças passavam grande parte do tempo estudando e brincando. Perguntados sobre a rotina na casa e a convivência familiar,surgem fortes lembranças das brincadeiras e do tempo da convivência com os irmãos e amigos. Afirmam, que não havia a necessidade de ajudar no sustento da casa, "nossotrabalho era estudar" (Senhor Luís, RTE, 2016, p. 79) e eram muito cobrados em relação ao desempenho na escola. Tanto que o comportamento do Senhor Luís era motivo de tristeza para a sua mãe: "Minha mãe até pouco tempo lembrava dessas coisas. Ela chegava a chorar. "(Senhor Luís, RTE, 2016, p.79).

O tempo de brincar foi conquistado através das gerações. Tempo que aos poucos foi incorporado na rotina infantil. As brincadeiras eram inúmeras, e a maior parte delaseram improvisadas e elaboradas pela criatividade infantil. O brincar desponta como o lugar onde a criatividade infantil comandava as ações. Através das brincadeiras as crianças expressavam seus: "aspectos inovadores e criativos de participação na sociedade" (CORSARO, 2011, p. 31).

"A brincadeira da gente aqui era pique, bandeirinha e uma tal de "escambia" que nós inventamos. "Escambia era assim: a gente pegava uma caixa de fósforo ou qual quer outro material. A garotada fazia uma roda e deixava a caixa ou o material no meio, você tinha que pegar a caixa e conseguir sair da roda, enquanto você não conseguia sair levava soco. Quando você saia tinha que sair correndo e achar uma porta e ai era ponto, você ganhava. Outra brincadeira era um grupo contra outro 
grupo. A gente brincava assim: um grupo ia se esconder, ficava escondido no mato e o outro ia procurar. Depois que achava o grupo todo era a vez do outro grupo procurar. Nessa brincadeira eu tinha um amigo que fazia o seguinte: a gente ia se esconder e ficava assoviando lá no mato e não aparecia ninguém. E assoviava, assoviava, assoviava. Depois resolvia sair todo mundo do mato. Ele e a turma dele iam embora e deixavama gente escondido no mato feito bobos" (Senhor Luís, RTE, 2016, p.80).

"Muitas brincadeiras eram assim de improviso. Eu lembro que tinha uma árvore, uma mangueira lá perto e eu pegava a folha, eu aprendi com as crianças da escola e fazia um buraquinho no meio da folha. Tirava uma parte de um lado e a outra de outro, corria para fazer um cata-vento. Ficava correndo com aquilo e girava. Era uma beleza! Se amassasse a gente fazia outra e apostava para ver de quem girava mais, isso dependia também do vento" (Senhora Elizete, RTE, 2106, p. 69).

Com toda essa criatividade, o mundo infantil começa a ganhar espaço no mundo adulto. Segundo Corsaro (2011), a criança está sempre participando e integrando estas duas culturas: a das crianças e a dos adultos, que são complexamente interligadas. Para entender esta relação precisamos:

... examinar suas atividades coletivas com outras crianças e com os adultos. Também precisamos considerar as crianças como parte de um grupo social que tem um lugar na estrutura social mais ampla. (CORSARO, 2011, p. 40)

O mundo adulto e o mundo infantil começam a apresentar sinais de integração, porque antes mesmo que as crianças estivessem integradas as atividades cotidianaspermaneciam separadas do mundo adulto

"O que eu mais me lembro, quando falo é do rio. É tomar banho de rio que era assim aquela praia, aquela areia branquinha como se fosse uma praia mesmo. E a água clarinha, pescando e catando peixes. Com meus irmãos eu passava à tarde inteirinha ali brincando. Papai dizia: Vai, vai, aproveita para tomar banho de rio, sua mãe está tirando um cochilo. Ela não gostava porque era um tal de garganta inflamada! As vezes ele até ia com a gente para ver a nossa farra. Eu lembro disso..." (Senhora Elizete, RTE, 2016,p. 68).

"A gente brincava todo dia! Isso era todo dia! Paizinho $e$ mãezinha deixavam a gente ficar na pracinha até tarde, mas uma coisa a gente respeitava, era o "psiu" de paizinho. Ele fazia três vezes e os três irmãos iam embora. Antes da luz da usina apagar, ele chamava a gente para casa" (Senhor Luís, RTE, 2016, p. 80).

A infância estava inserida na história da cidade: inauguração da nova igreja católica, a missa que acontecia sempre antes do período da moagem de cana, 
inauguração do cinema e do hospital. O progressoaos poucos foi modificando a vida local. As crianças tanguaenses completamente inseridas neste processo onde "a criança e sua infância são afetadas pelas sociedades e culturas que integram. Essas sociedades e culturas foram, por sua vez, moldadas e afetadas por processos de mudanças históricas"(CORSARO, 2011, p.32). E assim, com o progresso chegou a primeira televisão da cidade, que foi comprada pelo dono da padaria que colocava a disposição para que a população pudesse assistir no horário de seis às dez da noite. Chegaram também os primeiros brinquedos industrializados nas mãos das crianças, diferente da infância das gerações anteriores, que improvisavam seus brinquedos e formavam para si o pequeno mundo das coisas imagináveis:

... a Terra está repleta dos mais incomparáveis objetos de atenção e exercício infantis. E dos mais apropriados. Ou seja, as crianças são inclinadas de modo especial a procurar todo e qualquer lugar de trabalho onde visivelmente transcorre a atividade sobre as coisas. Sentem-se visivelmente atraídas pelo resíduo que surge na construção, no trabalho de jardinagem ou doméstico, na costura ou na marcenaria. Em produtos residuais reconhecem o rosto que o mundo das coisas volta exatamente para elas, e para elas unicamente. (BENJAMIN, 2012, p.17)

As crianças voltam seus olhares e seus desejos para os brinquedos industrializados, que começam a ser objetos de desejo da infância. Ocorriamtransformações na vida e na infância:

"A primeira televisão que nós tivemos aqui em Tanguá foi dentro da padaria de José Vaz. Ele chegava colocar bancos pra gente sentar dentro da padaria. E todo mundo, na hora dos bons programas, ia para lá. Eu lembro muito da TV Tupi que passava desenhos. Tinha dia que a gente saía para jogar bola e parava lá, só para assistir os desenhos" (Senhor Luís, RTE, 2016, p. 85).

"Eu me lembro dos brinquedos... porque eu tive uma fase na minha vida que minhas irmãs me davam de presente bonecas com cabelos e com os olhos que mexiam. Essas coisas elas não tiveram. Porque as bonecas das minhas irmãs mais velhas eram aquelas que tinham os olhos desenhados. Eu já tive boneca que piscava! Aquilo para mim foi um..." (Senhora Elizete, RTE, 2016, p. 69).

Com tudo isso,a relação entre meninos e meninas tambémcomeça a sofrer transformações, ambos agora brincam juntos no âmbito familiar e na escola. E as meninas começam a ter o prazer de descobrir as brincadeiras que antes só eram permitidas aos meninos: "As vezes meninos e meninas brincavam juntos, mas 
outras vezes separados. As meninas brincavam mais de roda e a gente correndo" (Senhor Luís, RTE, 2016, p.77). A senhora Elizete complementa:
"Mas eu gostava mais de brincar, não era muito de boneca, eu gostava mais era assim carrinhos, eu tinha uns carrinhos assim pequenininhos e tinha perto da garagem uma ribanceira e a gente cavava e fazia tipo uma serra e eu ficava de carrinho brincando. Gostava muito de carrinho!" (Senhora Elizete, RTE, 2016, p. 69).

Ganha destaque uma infância livre. Liberdade que deixou saudade, como expressou os relatos do senhor Luís e da senhora Elizete.

\begin{abstract}
"Ah... uma magia! Minha infância foi uma magia! Tudo muito colorido! Tudo tinha cor! Na minha infância eu tive muita liberdade, muito carinho. Não me faltava nada dentro das limitações da época" (Senhora Elizete,RTE, 2016, p.73)

"Liberdade! Naquele tempo a gente tinha liberdade! Você podia tomar banho de rio, caçar preá. Você andava daqui até lá em cima sem medo de nada!" (Senhor Luís, RTE, 2016, p. 84).
\end{abstract}

Através dos relatos podemos conhecer uma infância em Tanguá com fortes marcas. Ouvimos histórias que nos apresentam um espaço que foi conquistado - o espaço da infância. De um lugar totalmente envolvido com o mundo adulto, para um lugar que começa a ficar específico. É interessante observar o quanto a escola teve um papel fundamental no processo de conquista do espaço da infância na vida da cidade. Quando juntas na escola, as crianças começaram a trocar experiências e tiveram espaço e tempo para desenvolverem sua leitura do mundo.

Quando estavam maior tempo no espaço doméstico envolvidas nas atividades cotidianas, as crianças tinham maior consciência da vida e dos obstáculos a vencer, mas tal fato não as impedia de ser criativas em meio a tantas dificuldades. Uma infância, que pela sua força, conquistou o seu espaço e participou ativamente da história da cidade, mesmo quando parecia ser totalmente dirigida pelo mundo adulto. As memórias de infância dos velhos moradores de Tanguá nos apresentaram uma criança tanguaense que ao longo do tempo conquistou seu espaço e ajudou a construir a história da cidade.

Como foi apresentado no início deste capítulo, a organização das memórias de infância por gênero e gerações se posiciona contra a esse tempo "vazio e 
homogêneo" que o progresso impôs à vida na cidade. As memórias de infância aqui apresentadas são tempos especiais, cheios de "tempos de agora", que segundo Benjamin (2012), estão repletos de sentido e enriquecem a experiência do viver.Esta organização procurou apresentar uma infância ativa que não se limitou a internalizar passivamente a sociedade e a cultura, mas uma infância que contribuiu ativamente para a produção e para as mudanças culturais. Esta afirmação tem como base a noção de que "a infância é como uma estrutura social, onde a mesma é tanto um período em que as crianças vivem suas vidas quanto uma categoria ou parte da sociedade" (CORSARO,2011,p. 42), ou seja, embora a infância seja um período temporário para a criança, é uma categoria estrutural permanente na sociedade.

$\mathrm{Na}$ leitura das entrevistas surgiram temas recorrentes ou categorias de análise, que neste estudo, foram preservadas para garantir a totalidade dos discursos e dar conta dos significados comuns às narrativas. Emolduradas por gestos, olhares, sorrisos e lágrimas, as memórias de infânciase colocaram como flores que dirigiram sua corola para o sol. Como afirma Benjamin(2012): "assim como o passado, que graças a um misterioso heliotropismo, anseia por dirigir-se para o sol que se levanta no céu da história" (p. 243). Se lançando no céu da história, as categorias emergiram das memórias de infância mostrando sua importância na vida de cada entrevistado. As categorias que mais se destacaram foram: a casa, a escola, as brincadeiras, o espaço da cidade, a liberdade e o trabalho na infância.

A casa se mostrou como um importante lugar de convivência familiar. A partir da casa o mundo se expandia para a cidade. A casa sem muros onde não havia a separação entre o que era rua e o que era quintal. A casa da família onde as primeiras relações eram construídas, lugar de proteção, de afeto e de preparação para a vida adulta, lugar de trabalho com as responsabilidades e cuidados diários para o sustento de toda a família.

Também como um importante lugar de preparação para a vida adulta, surge a escola. Tão citada nas entrevistas, era um lugar de encontros e valorização, mas com regras rígidas, broncas e castigos. Como um espaço de convivência teve um papel fundamental para que a infância da cidade pudesse avançar em visibilidade e valorização por parte dos adultos. Interessante que, mesmo o senhor Luís que não gostava de estudar, gostava da escola e das "coisas da escola". 
Dentro e fora da escola aconteciam as brincadeiras. Tão significativas no universo infantil, elas apareceram em todos os depoimentos. Inspiradas na cultura popular ou improvisadas, representam a criatividade infantil e uma maneira peculiar da infânciase inserir e compreender a vida.O espaço dacidade era o predileto para a realização das brincadeiras. Apreciavam andar livres pela cidade, tomando banho de rio, brincando na praça, subindo em árvores e chupando cana e laranja. Tais ações representam para o velho morador a liberdade que eles desfrutavam e que, segundo os mesmos, não existe mais.

A relação entre infância e trabalho marcou profundamente os primeiros depoimentos. Trabalho e brincadeira se misturavam, pois ao mesmo tempo em que, trabalhavam, brincavam. Trabalhavam dando banhos nos animais no rio, fazendo farinha, confeccionando cordas, cozinhando, mesmo que para isso fosse necessário se apoiar no tijolo de barro para alcançar a altura do fogão de lenha. E nestas atividades também brincavam! Uma infância que representava desejo de ser adulto e explorar coisas novas.

Significativas memórias de infância e ricas lembranças da vida na cidade de Tanguá que podem enriquecer a vida das crianças. Esta pesquisa defende que este enriquecimento pode acontecer através do resgate e valorização do trabalho com a memória em espaços de Educação Infantil. Este tema será tratado no próximo capítulo. 


\section{6. $O$ encontro entre o passado, o presente e o futuro na Educação Infantil}

Da voz e mãos de um velho, o fim da vida é conhecido em seu início.

(OLIVEIRA, 2011, p. 41)

Tantas histórias e tantas lembranças se fazem conhecer através das experiências de vida dos velhos moradores e neste capitulo estas memórias serão analisadas sobo prisma das possibilidades educativas que estas possuem para as futuras gerações da cidade. O interesse desta pesquisa está em descobrir o lugar da infância na cidade de Tanguá e realizar uma reflexão sobre a importância de que estas memórias cheguem às crianças. Isso através do contato com os velhos e a escuta atenta de suas narrativas e histórias de vida.

Nesta pesquisa, as histórias narradas não são histórias feitas, isto é, produzidas literalmente e muito menos, narrativas postiças. São histórias vividas, atravessadas visceralmente pelos dramas cotidianos como diz Oliveira (2011, p.22):

As lembranças, banhadas pela experiência de vida e pelo afeto, recompõem a arte de contar, uma prosa que não conhece cronômetro. Sem pressa, a cultura oral, fundada no ato de conversar, produz e preserva muita sabedoria, revelando a quem sabe ouvir o "lado épico da verdade", como mostra Walter Benjamin.

O lado épico da verdade, segundo Benjamin (2012) é a sabedoria, que pode estar presente no dia a dia de velhos e crianças, pois a criança ao ouvir as histórias de vida transformam-nas em uma imensa aventura cheia de enigmas e como é ouvinte atenta, nunca se cansa de pedir: "conta mais uma vez". A criança está sempre disposta a saborear novamente o prazer da narrativa. Narrativa que, segundo o próprio Benjamin (2012), está definhando, está em perigo de vida, e por este motivo, reiteramos o valor da convivência entre o velho e a criança como contraponto ao desdobramento da barbárie (KRAMER, 2009).

Segundo Bosi (2015), crianças e velhos estão situados às margens da sociedade, mesmo que de forma sutil. Os velhos estão presos ao que um dia foram, e as crianças ao que um dia serão. Alijados, na maior parte dos casos, do mercado produtivo, velhos e crianças possuem muitos pontos em comum. Diferentes dos economicamente produtivos, que estão presos ao tempo fragmentado do relógio à velocidade do dia a dia, as crianças e os velhos podem 
transformar o seu cotidiano, não só pelo ato de contar histórias, mas porque trocam experiências nutrindo-se mutuamente.

No convívio entre velhos e crianças, as transformações que se operam são múltiplas e recíprocas. Os velhos educam as crianças e ao mesmo tempo são reeducados por elas. Se há uma socialização, esta precisa ser vista não de um modo unívoco (dos velhos para as crianças) e sim mediante relações recíprocas, num movimento que a todo tempo constrói e reconstrói os sujeitos (CORSARO, 2011). Assim em acordo com Paulo Freire (1987, p.86) "Ninguém educa ninguém - ninguém se educa a si mesmo - os homens se educam entre si, mediatizados pelo mundo". Portanto, não se trata de supor a ação de uma geração sobre a outra, mas de considerar que velhos e crianças se reconstituem e se renovam como sujeitos no desdobrar deste novo convívio. A criança oferece a força, a fragilidade e a espontaneidade. E o velho a experiência transformada em sabedoria, guardada na memória e oferece, também, a capacidade de "unir o começo ao fim, tranquilizando as águas revoltas do presente, alargando as margens", conforme escreve Bosi (2015, p. 82).

Esta pesquisa pensa em uma educação entre gerações que se constrói na história e supõe gerações em movimento. Desse modo, abandona-se a ideia restrita de geração como algo dedutível de um momento já vivido (OLIVEIRA, 2011). Nesta construção permanente, a geração além de ser vista como depositária de uma época, e portanto, banhada por um tempo datado historicamente, pode além disso ser percebida como modeladora das marcas da sua passagem, no tempo e no espaço. Tais vestígios estariam impressos na cultura material e simbólica, que comporia o que Oliveira (2011, p.335) chama de "conjunto de oferendas das gerações, umas às outras”. Trata-se de um movimento, de algo que está se desdobrando, são legados que se renovam, onde não é apenas uma geração que dá algo de si enquanto outra, passivamente fica sendo receptora inerte das dádivas. Um convívio de gerações, nesta perspectiva, não comporta linearidade e, portanto não se resume na passagem de sabedoria dos velhos para as crianças. E mesmo sem saber, as crianças podem transmitir muito as gerações mais velhas.

O encontro entre velhos e crianças traz possibilidades de renovação de uns e outros, mas os ingredientes deste saber não são simplesmente transmitidos como quem passa um anel entre as mãos, isso fazendo alusão a uma brincadeira tradicional infantil. São trabalhados na mente de quem acolhe e ingressam na vida 
dessa pessoa como conquista. Corsaro (2011) destaca que as experiências são incorporadas dialeticamente e a assimilação não se faz por soma ou aglutinação, mesmo que muitas vezes esta seja a aparência. Sobre este aspecto adverte que as teorias sociológicas da infância devem se liberar da doutrina que considera o desenvolvimento social infantil unicamente como a internalização isolada dos conhecimentos e habilidades de adultos pelas crianças. Se assim fosse, sempre haveria passividade do receptor como se a cultura fosse do emissor e se depositasse no receptor. Velhos e crianças podem interagir na vida em comum e se modificarem reciprocamente. Esta é uma possibilidade que se inaugura a partir da coexistência de gerações diferentes, numa dada situação social.

Os avós nascidos em outro tempo, habitam e vivem este tempo, juntamente com seus netos. Essa diferença confere aos mais velhos a condição de portadores do passado no presente e, graças ao burilar da memória, oferecem oralmente a seus netos uma cultura banhada na história vivida. (OLIVEIRA, 2011).

Só a coexistência, todavia, nada garante. Como lemos nos relatos dos moradores antigos de Tanguá, a cidade vive a segregação de famílias com seus filhos em relação a outros membros da sociedade por classes, raça, etnia, gênero e idade. Sobre isso, relata o Senhor Luís:

\footnotetext{
"Naquela época não havia televisão e toda tarde se reunia um grupo para visitar a casa de alguém. A gente ia fazer uma visita e chegava lá era bem recebido. Hoje você tem medo de ir na casa de alguém e atrapalhar alguma coisa. Atrapalhar ver um programa de televisão, uma conversa. Naquele tempo nosso programa nas tarde de sábado e domingo era visitar alguém e tomar um café. As pessoas faziam queijo e comíamos queijo. Quando não era na casa de um era na casa de outro. Hoje não se faz mais isso não! Hoje é uma coisa bem diferente mesmo! (Senhor Luís, RTE, 2016, p.85).
}

Um importante motivo para o isolamento familiar, em todas as classes das sociedades industrializadas, é a segregação etária. Segundo Corsaro (2011), a fragmentação das instituições de acordo com a idade e o elevado nível de mobilidade social nas sociedades modernas significou que a interação de pessoas de diferentes idades ocorre com menos frequência e que sua importância social foi reduzida. Este fato é lamentável, pois uma geração tem muito a oferecer a outra.

Na cidade de Tanguá é comum a participação ativa dos velhos na vida cotidiana. Eles estão nas igrejas, nas lojas, nos mercados, nas praças e muitos fazem caminhada como prática para cuidar da saúde. E em alguns momentos, quando estão caminhando, estão indo visitar seus netos ou buscá-los na escola. 
Mas ir até o portão da escola ou participar das reuniões escolares, não é suficiente. Precisam ser criadas ocasiões onde os velhos moradores entrem em contato com os alunos da Educação Infantil. São necessários programas para que velhos e crianças possam exercer atividades coletivas na Educação Infantil e, assim, as crianças tenham garantido o seu direito à cultura e à cidade.

Dentro das escolas, em muitos casos, a cultura é vista como um conjunto de coisas e habita fortemente a ideia de que cultura é uma soma de objetos, como: quadros, esculturas e livros, que são fortemente valorizados. Não se trata aqui de rejeitar como cultura este legado de gerações precedentes e sim de questionar uma cultura que seja postiça, distante, inacessível e sem nexo com a vida. Segundo Oliveira (2011), a cultura não pede de nós uma reverência mistificadora, ela se produz no interior das relações sociais e existe para promover a humanidade em nós. Sendo assim, esta pesquisa defende que as crianças de Tanguá devem aprender a história da cidade não apenas através dos livros e das fotografias antigas. As histórias de vida dos velhos moradores podem trazer uma aprendizagem enriquecedora e humanizadora da cultura. Quando chegam às crianças, memórias "são vida pensada" (BOSI, 2015) que emergem e mergulham no cotidiano, que podem libertar a cultura do seu caráter mítico e cumulativo.

Mediatizados pela cultura, velhos e crianças vão se constituindo e se reconstruindo mutuamente como sujeitos. Isso acontece por um trabalho de criação, recriação, produção e reprodução da cultura. Mas para que a cultura seja um processo de construção, como prática pensada e humanizadora, ela precisa simultaneamente construir-se criticamente em relação à cultura industrializada e à cultura que se exerce como dominação. A cultura oral com sua lentidão, com sua inteireza, com sua proximidade é uma prática para ser vivida e pensada e pode ajudar a romper com a cultura industrializada e sem sentido que, em muitos casos, predomina nos projetos pedagógicos na Educação Infantil.

As memórias de infância de velhos moradores de uma cidade são:

... uma cultura que ainda se constrói fazendo, embalada por conselhos, por brinquedos e brincadeiras, por histórias que não são histórias feitas e sim vividas, e pelo trabalho, desde as tarefas pesadas e invisíveis ditadas pela sobrevivência até o puxar pela memória, mantendo vivo o que materialmente não existe mais. (OLIVEIRA, 2011, p. 40)

Nas memórias de infância dos velhos moradores está a essência da cultura de uma cidade que pode ser apresentada às crianças. Bosi $(2015$, p.416) em 
Memória e Sociedade - Lembranças de velhos diz que: “esse passado concentrado no presente é que cria a natureza humana por um processo contínuo de reavivamento e rejuvenescimento". Essência que habita na tradição da qual os velhos são depositários e podem compartilhar com as crianças, levando-as a travar contato e a aprender a admirar algo que, até agora, não fez parte do seu mundo. Em contato com esta cultura, as crianças podem desenvolver a sensibilidade para um universo que não é o seu e se descobrirem capazes de viver ativamente a experiência do outro. É muito importante ter o passado incorporado ao presente, pois só assim, as crianças poderão vislumbrar possibilidades de inovação consciente no futuro.

Através dos velhos as crianças podem imaginar um mundo real ao qual não pertencem e podem começar a pensar num mundo futuro. A experiência do passado lhes dá meios de imaginar o futuro. Através dos velhos as crianças aprendem todo um ciclo de vida, o que é ter filhos e ter vivido uma vida inteira. "Da voz e mãos de um velho, o fim da vida é conhecido em seu início" (OLIVEIRA, 2011, p. 41).O velho através da criança tem a chance deressignificar o final da vida epode assim atestar seu inacabamento e, através deste processo, ter o desejo de aprender e se lançar sob a vida com novas perspectivas e desejos. Muitas vezes, o velho deixou realizações e projetos em curso e que estão a espera de alguém que se interesse em completar esse "desenho da vida" (BOSI, 2015). O velho pode ter na criança a esperança de que este desenho inacabado pode ser finalizado. No entanto, múltiplas possibilidades se formam no encontro entre velhos e crianças.

Tão importante quanto o contato com a cultura, as memórias de infância dos velhos moradores,podem proporcionar um conhecimento mais critico sobre a história da cidade. Não estamos falando aqui de uma cidade didatizada e sem vida, relatada nos livros didáticos. O importante é que as crianças tenham acesso a uma história da cidade que foi vivida, experimentada e que foi contada pelos seus moradores.

Em sua pesquisa: Os "pequenos" e a cidade: O papel da escola na construção do direito à cidade, Maria Tereza Goudart Tavares (2007) investigou a cidade no contexto escolar, refletindo sobre a tríade escola/cidade/ alfabetização onde colocou em discussão o direito à cidade como pressuposto de cidadania para 
os sujeitos escolares. A centralidade deste estudo está em ter a cidade como um espaço social de práticas educativas, e sobre isso escreve:

O estudo justifica-se pela centralidade da cidade como espaço social de práticas educativas, um livro de espaços potencialmente eminente de um outro "ethos" de confiabilidade social, cabendo portanto, aos sistemas escolares interagir na e com a cidade... (TAVARES, 2007, p. 70)

Realizada em uma escola pública do bairro Jardim Catarina no município de São Gonçalo, Estado do Rio de Janeiro, a pesquisa traz importantes contribuições para se pensar no direito que as crianças possuem à cidade e o papel da escola pública na constituição deste direito, isso porque este processo não se dá naturalmente. $\mathrm{O}$ direito à cidade exige uma intencionalidade por parte da instituição escolar:

Partíamos do pressuposto de que era fundamental desenvolver uma escuta sensível e uma compreensão ativa das percepções e vivências dos sujeitos escolares sobre a cidade, especialmente porque a aprendizagem da vida na cidade, a fruição amorosa e responsável da metrópole contemporânea não é natural, muito menos óbvia. A aprendizagem da vida na cidade exige uma intencionalidade e dispositivos formadores que a instituição escolar congrega quase como inerente à sua constituição histórica, como parte de sua natureza institucional. (TAVARES, 2007, p. 71)

$\mathrm{O}$ direito à cidade, segundo a pesquisa, aponta a necessidade de considerarmos o corpo e seus sentidos, pois é através deles que os sujeitos estão no mundo, habitam e se apropriam do espaço. Na tríade habitante/ identidade / lugar (TAVARES, 2007), o homem possui modos de estar no mundo, influenciados pelo corpo e seus sentidos. Com o corpo exploramos o espaço e com os sentidos e as experiências nele vividas ganham significado e criam laços profundos de identidade. A partir desta reflexão, podemos pensar que o direito à cidade por parte das crianças, envolve a exploração dos lugares e espaços da cidade, contudo estar nestes espaços ganha maior inteireza quando realizados à luz das memórias sobre a cidade.

Não é apenas estar num lugar e saber da história oficial do lugar, é preciso levar em conta que:

... a história tem uma dimensão social que emerge no cotidiano das pessoas, nos seus modos de vida, nas suas práticas culturais, nas relações sociais, no modo pelo qual vivem e dão sentido ao local, ao município, ao bairro, à escola, enfim, a cidade e seus territórios. (TAVARES, 2007,p. 88).

Estes pormenores, que chegam somente através das histórias de vida de tempos passados, podem despertar nas gerações posteriores, mediante um trabalho 
intencional, o desejo de conhecer, ter e de compreender a cidade. A criança tem direito à cidade para uma vida com mais cuidado, respeito e cidadania.

O direito à cidade se inscreve não somente como uma luta dos pequenos escolares pelo acesso aos seus equipamentos socioculturais , mas sobretudo, pela perspectiva de se discutir e refletir com os sujeitos escolares uma cidade mais democrática, menos excludente, mais humanizada pela fruição amorosa e responsável de sua gente. (TAVARES, 2007, p. 73).

Nas memórias de infância dos velhos moradores estão depositadas a cultura e a vida da cidade. Este estudo defende a elaboração de propostas que ofereçam as crianças a oportunidade de entrarem em contato com o passado e com a vida na cidade, contato este que pode contribuir para a construção do mundo infantil Cultura de Pares (CORSARO, 2011). Os entrevistados expressam esta preocupaçãoquando relataram o desejo de que as crianças possam ter uma relação com a cidade igual a que eles tiveram. Pensamque as crianças de hoje estão perdendo um tempo precioso.

"Eu acho que devido a modernização estão deixando de ter mais brincadeiras. Naquela época a gente podia sair e andar para qualquer lugar, acho que falta um pouco de segurança e liberdade. Essa preocupação não passava pela nossa cabeça. Hoje falta para as crianças essa liberdade com tranquilidade" ( Senhor Rogério, RTE, 2016,p.25).

"Então, a gente andava tranquilamente e não tinha medo de nada. Agora, o comportamento da gente era um e o das crianças hoje é outro completamente diferente. Agora, a época em que eu vivi era muito mais tranquilo que agora. Hoje estamos precisando de mais lugares para as crianças brincarem: parquinhos e lugares arborizados" ( Senhora Maria Augusta,RTE, 2016, p. 9).

Com esta liberdade as crianças viviam a cidade e construíram com ela uma relação como nos escreveu Tavares (2007) em sua pesquisa, uma relação de amorosidade e afeto:

"Sinto saudade da liberdade de vida que a gente tinha! Naquela época a gente caçava passarinho, pescava no riachinho que passava atrás da casa de vovó e descia o morro com canoas de folhas de coqueiro" (Senhor Luís, RTE,2016, p. $85)$.

"Minha infância foi uma infância muito gostosa! Era muito gostoso antigamente. As crianças de hoje estão perdendo muitas coisas. Perdendo até na alimentação, porque com toda a pobreza a alimentação era muito boa. Tinha banana, tinha inhame, porque aqui em Tanguá todo mundo tinha a sua lavoura" (Senhor Salim, RTE, 2016, p. 63). 
Destacam-se os relatos de uma estreita convivência entre as gerações. Os entrevistados contam que conviver com gerações mais antigas era algo comum e a casa dos avós era um importante espaço de convivência:

"Lembro-me da carne seca que minha avó fazia. Na casa da minha avó tinha de tudo! Lá tinha um quartinho onde ela pendurava a carne seca que ela fazia. Minha avó dava um pedaço de pão para a gente, e a gente ia no quartinho cortava um pedaço de carne seca, botava dentro do pão e saia correndo para brincar" (Senhor Luís, RTE, 2016, p. 86).

Uma relação construída com respeito e afeto:

"Nós respeitávamos os mais velhos e pedíamos a benção. Era muito difícil encontrar com um velho e não pedir a benção" ( Senhor Salim, RTE, 2016, p. 64).

Realizar um trabalho na Educação Infantil que garanta o contato com as memórias do passado,o direito à cidade e o direito à cultura mais ampla é realizar uma educação que "escova a história a contrapelo" (KRAMER, 2009). Isso significa pensar o mundo e os acontecimentos ao contrário, ou seja, na direção contrária à esperada. Para tal, é necessário realizar um trabalho crítico na Educação Infantil.

Pensar a educação e a prática educativa à luz dos ensaios e fragmentos de Benjamin exige indagar sobre o tempo em que vivemos e sobre o papel da escola; exige reverter a posição da escola que, com frequência, quer transmitir o passado para preparar um suposto futuro, mas deixa o presente intocado, sem mudança, muitas vezes sem sentido. (KRAMER, 2009, p. 299)

"Escovar a contrapelo" a educação exige mudanças, pois de nada adiantam as intenções sem alterações nas condições materiais e sociais para que estas aconteçam. Devemos rever: as relações entre crianças e adultos e neste aspecto é fundamental o papel da narrativa para recuperar o sentido de ensinar e de aprender; pensar em alternativas pedagógicas onde professores e alunos sejam incentivados a recuperar a capacidade de deixar rastros e serem autores; a posição da criança considerando-a na sua posição de sujeito da história, no lugar de percebê-la de forma descontextualizada, fora de uma classe social, de uma cultura, etnia e de sua história (KRAMER, 2009).

A Educação Infantil necessita romper com projetos pedagógicos que apenas pretendem divulgar e implantar novidades, mas não modificam condições concretas para a transformação da escola, apenas lançam palavras e discursos sobre a escola. Projetos que não valorizam a tradição e fazem das crianças e dos 
adultos, peças de uma linha de montagem, sem significado com a perda da experiência humana coletiva. Frente a este grande desafio, as memórias de infância podem nos ajudar a humanizar o presente, qualificar e aprofundar as relações entre as gerações e a: "resgatar do passado, na memória, na escuta de vozes que foram emudecidas que reside a possibilidade de realizar o encontro secreto marcado entre as gerações precedentes e a nossa" (KRAMER, 2009, p. 291). 


\title{
7. Considerações finais: 0 que podemos aprender quando lançamos um olhar no passado
}

\begin{abstract}
Narrar é reativar a vivência, é olhar para o passado com a experiência do presente. E, neste sentido, escutar a própria história ao recontá-la constitui-se como um processo formativo. Recontar uma história é atualizá-la para aquele que escuta e para si mesmo e, por isso, ela pode curar. Isso é o que aprendemos com as histórias. (PENA, 2015, p. 158)
\end{abstract}

Para que as histórias de vidas fossem protagonistas, eu pesquisadora tive que me diluir e deixar que os entrevistados e suas falas sobressaíssem. Mas durante todo o processo desta pesquisa, o aprendizado foi intenso, e posso dizer que essa experiência me marcou significativamente. Concluindo este trabalho, abro espaço para retomar meu lugar nesta história. Como apresentei no primeiro capítulo desta dissertação, as histórias que meus avós e meus pais me contaram sobre a vida em Tanguá, me fascinavam e ficaram guardadas em minha memória. ;lembranças de um tempo bom, tempo de escuta e interação entre eu, meus pais, meus avós e a cidade de Tanguá. Não aprendi a história da cidade somente na escola. Minhas mais ricas e interessantes aulas sobre Tanguá aconteceram quando ouvia as histórias do passado, e isso acontecia especialmente na varanda da casa dos meus avós.

Estas histórias ajudaram a constituir o que sou hoje e fortaleceram minha relação com a cidade. A minha cidadania tanguaense foi se construindo no entrelaçar dos tempos - as histórias do passado e a minha própria história. As vivências foram impregnando de sentido o que ouvia dos mais velhos, pois algumas coisas eu tive a oportunidade de experimentar, outras foram apenas alimentadas na minha imaginação de criança. Nesta mistura entre presente e passado, aprendi a ter uma imagem positiva do lugar onde vivia, isso apesar das dificuldades cada vez mais evidentes, numa cidade simples do interior do Estado do Rio de Janeiro.

Com um ritmo pacato e tranquilo a cidade sempre teve um número significativo de velhos moradores participando ativamente da vida como um todo. Era comum a convivência entre avós e netos e entre velhos e crianças. Convivência que se baseava numa relação de muito respeito, mas também de muito afeto. Uma convivência que trazia humanização das relações. E foi neste ambiente que cresci e me constitui como sujeito. Penso o quanto as crianças estão 
perdendo em não construírem essa relação de afeto com os velhos moradores e com a própria cidade.

Como professora de educação infantil da rede municipal de ensino da cidade de Tanguá, comecei a desenvolver um olhar atento para a forma como as crianças interagiam com a cidade e aprendiam a história local. Ficou claro que diferente de mim, que tive a oportunidade de conviver com velhos moradores, as crianças tinham poucas oportunidades de realizarem trocas significativas com os velho e com a cidade. $\mathrm{O}$ estudo da história da cidade surgia somente por razão da comemoração do seu aniversário e isso acontecia bem rapidamente no mês de novembro. O estudo da história da cidade, na maior parte dos casos, era conduzido por um professor que também só conhecia a história de Tanguá através de livros ou fotos antigas. Tais fatos revelam o caráter empobrecedor do contato do professor e da criança com a história da cidade.

Tal problemática me incomoda deste a especialização em Educação Infantil e continuaram comigo até o mestrado. Queria continuar estudando e pesquisando sobre a interação das crianças com a cidade para entender o lugar da infância na cidade de Tanguá. Conhecer as histórias de vida através das memórias de infância foi a lente escolhida para olhar o passado e com ele compreender o presente.

Ao lançar um olhar no passado, trazendo suas memórias de infância, os velhos moradores iniciaram também um movimento de volta ao presente, uma reflexão sobre o que nos tornamos hoje em função do que fomos ontem. Para tal, foi necessário que eu, pesquisadora, aprimorasse a escuta, no intuito de promover encontros onde a narrativa pudesse fluir, não só através das palavras, mas de gestos e olhares. Cada vez mais pensava sobre como as crianças necessitam desses gestos e olhares que só o narrador pode impregnar a sua narrativa (BENJAMIN, 2012).

A memória possui a capacidade de proporcionar o contato com o tempo pretérito de forma que possamos ressignificá-lo e dessa forma compreendê-lo melhor. A memória pode também ajudar a pensar sobre vários aspectos da vida na cidade. Esta pesquisa defende que as crianças necessitam de tempo para mergulhar na história, tempo para uma escuta atenta e cheia de vida. Por este motivo, a memória, fio condutor desta pesquisa, pode trazer grandes contribuições para a Educação Infantil e para a vida em toda a cidade. Colocar a criança em contato com essas lembranças é dar a ela a oportunidade de recriar a história, 
construindo subjetividades, onde o coletivo tenha um valor significativo em sua vida.

Ainda como ponto relevante deste estudo, destaco o valor da memória como mecanismo que possibilita pensar em novas ações dentro dos espaços de Educação Infantil. Ações que tragam esperança, a solidariedade, a humanização das relações e o maior contato das crianças com a memória de suas cidades. Uma memória que não apresenta somente a história social, que está viva nos relatos dos velhos moradores e que não se transmite de forma fria apenas com ações mecânicas, mas uma memória narrada onde as crianças dialogam com seu passado.

Através das memórias de infância, existe a possibilidade de mergulhar em histórias cheias de particularidades que revelam a faces de uma cidade e de uma infância que a maior parte dos moradores não conhecem. Visitar a casa, aescola, a família e as brincadeiras de infância através das lembranças, revelou uma vida infantil fortemente marcada pelo trabalho e pela necessidade de ajudar no sustento familiar. Revelou uma infância que por anos esteve marcada por uma submissão ao mundo adulto. O trabalho e a relação com a família e com a escola descortinaram uma infância que primeiramente era sem voz e que aos poucos foi conquistando seu espaço, pois com sua capacidade de recriar o mundo a infância buscou seu lugar e sua forma de expressão. Com as brincadeiras e com o trabalho as crianças conquistaram seu espaço na vida da cidade, revelando sua forma particular de participar da vida. Havia o trabalho que era pesado, duro e cheio de responsabilidades, mas havia também o trabalho que era lúdico e cheio de prazer.

As brincadeiras livres pelos espaços de Tanguá foi o ponto alto de muitas recordações. Andar livremente pela cidade explorando os espaços através das brincadeiras. Brincadeiras que muitas das vezes eram improvisadas eimventadas pela imaginação infantil e que produziram recordações repletas de afeto e sentimento de pertencimento. Tanguá não era uma cidade que estava somente no papel (fotos e livros), Tanguá era uma cidade real que as crianças sentiam e experimentavam nos banhos de rio, nas brincadeiras na rua, na praça e nos canaviais. Com a valorização destas recordações, Tanguá tem a possibilidade de avaliar o papel dado hoje às crianças e como elas se inserem na vida da cidade. 
Neste estudo os autores Eclea Bosi, Walter Benjamin e Willian Corsaro ajudaram a refletir sobre a importância da narrativa na educação de novas gerações. Para Ecléa Bosi a essência da cultura pode atingir as crianças através da fidelidade da memória. Fidelidade esta que o velho possui, pois com a capacidade de unir o passado ao presente, o velho trata a memória como um tesouro inestimável e é a pessoa mais adequada para apresentar as crianças tempos que não foram vividos por elas. Nas lembranças aqui apresentadas podemos constatar com Bosi (2015) que realmente os velhos cuidam das memórias como um tesouro. Cada palavra foi dita com cuidado, querendo sempre ser o mais fiel possível ao fato acontecido, fiel também aos sentimentos que sempre extrapolam as narrativas, os olhos muitas vezes ficavam molhados pelas lágrimas.

Lágrimas, gestos, olhares, sorrisos e expressões - marcas do narrador em sua narrativa. Assim como nos falou Benjamin o narrador deixa suas marcas naquilo que narra, uma narrativa impregnada de sentido, de vida, de humanização. Uma narração que é inimiga da pressa e do imediatismo que entra no ouvinte, onde há momentos que a história parece estar em nós. E este foi o sentimento que eu, pesquisadora tive em muitos momentos ao ouvir as histórias de vida. Histórias cheias de conselhos, conselhos estes tecidos na substância da vida vivida (BENJAMIN, 2012), dados com cuidado numa relação que busca se construir cheia de significados. O saber de que dispõe o narrador não é um saber meramente técnico e nem tampouco um saber de si auto referencial. Sua sabedoria implica no conhecimento histórico de formação de si em meio a um coletivo, do conhecimento das práticas, dos ritos e valores compartilhados e transmitidos pela tradição aos indivíduos. Sendo assim, na contramão das relações estabelecidas no mundo atual, com Benjamin (2012) podemos pensar em relações mais inteiras, verdadeiras e afetivas entre as gerações dentro da Educação Infantil.

Vimos através dos depoimentos que as crianças eram participantes ativas da sociedade, mesmo quando se pensava que estas estavam apenas sendo dirigidas pelos adultos em suas ações. Em todo momento, as crianças se esforçaram para interpretar e dar sentido à cultura da qual participavam e na tentativa de dar sentido ao mundo adulto, elas passaram a produzir coletivamente seus próprios mundos e suas Culturas de Pares (CORSARO, 2015). E possível afirmar que as crianças em Tanguá em todo tempo procuravam criar e desfrutar de sua própria infância e em nenhum momento era uma infância ingênua e romântica, a criança 
estava inserida em uma classe social, tinha participação ativa na cultura e por este motivo também produzia cultura (KRAMER, 2002).

Frente a tudo que aprendemos neste estudo sobre as memórias de infância, fica a pergunta: Até quando a Educação Infantil e a escola de modo geral irão se fechar para as memórias dos velhos moradores? Sendo que estas servem para se aprender sobre a história de uma cidade e da infância nela vivida.

Este trabalho defende que precisamos enriquecer as apropriações das crianças sobre o mundo adulto para incentivar as construções de suas próprias culturas e para melhor compreendermos as contribuições que as crianças podem dar e dão ao mundo adulto. Quantas vezes ouvimos que as crianças são o futuro da nossa cidade. Sim elas são o nosso futuro, mas isso não deve nos cegar sobre as ações em relação a como cuidamos de nossas crianças no presente. $\mathrm{O}$ contato com as memórias do passado, através do trabalho com a narrativa, dá a criança oportunidade de viver e explorar a cidade se mostraram fundamentais para que elas possam, desde a mais tenra idade, criar uma relação de pertencimento e de amorosidade com o lugar onde vivem.

Cuidado no presente que produzirá adultos mais conscientes no futuro e dará as crianças a oportunidade de participarem ativamente de sua própria infância. Sendo assim, esta dissertação se conclui na certeza de que as memórias de infância dos velhos moradores de Tanguá podem contribuir para a qualidade de vida da infância na cidade de Tanguá, isso é o que aprendemos quando lançamos um olhar no passado. 


\section{Referências bibliográficas}

BEAUVOIR, S. de. A velhice. Rio de Janeiro: Nova Fronteira, 1990.

BENJAMIN, W. Obras escolhidas I, Magia e técnica, arte e política. São Paulo: Brasiliense, 2012.

BENJAMIN, W. Obras escolhidas II, Rua de mão única.São Paulo: Brasiliense, 2012.

BIDINOTO, V. M. A história orla de vida de moradores do Bairro Ibitiruna de Piracicaba - SP: contribuições à educação ambiental.Dissertação de mestrado em Educação; Piracicaba: São Paulo: Universidade Metodista de Piracicaba UNIMEP, 2011.

BOSI, E. Memória e Sociedade: Lembrança de velhos.São Paulo: Companhia das Letras, 2015.

CORSARO, W. A. Sociologia da Infância. Porto Alegre: Artmed, 2011.

FREIRE, P. Pedagogia do Oprimido. Rio de Janeiro: Paz e Terra, 1975.

GANEBIN, J. M. História e Narração em Walter Benjamin. São Paulo: Perspectiva, 1999.

GOLDENBERG, M. A Bela Velhice. Rio de Janeiro: Record, 2015.

GUSMÃO, D.S. Por uma estética da delicadeza: ressignificando contos e imagens nas roças de Minas.Dissertação de mestrado em Psicologia. Rio de Janeiro: Pontifícia Universidade Católica do Rio de Janeiro - PUC-RIO, 2004.

HALBWACHS, M. A memória coletiva. São Paulo: Centauro, 2004.

IBGE - Instituto Brasileiro de Geografia e Estatística, 2010.

KRAMER, S. Por entre as pedras: arma e sonho na escola.São Paulo: Editora Ática, 2002.

KRAMER, S. Propostas pedagógicas ou curriculares da Educação Infantil: para retomar o debate. In: KRAMER, S. (Org.). Relatório de pesquisa "Formação dos profissionais de educação infantil no estado do Rio de Janeiro",2001.

KRAMER, S. Com a pré-escola nas mãos: uma alternativa curricular. São Paulo: Ática, 1986.

KRAMER, S.; SOUZA, S. J. (Orgs). Política, Cidade e Educação: Itinerários de Walter Benjamin.Rio de Janeiro: Contraponto/Editora PUC-Rio, 2009.

LÉLIS, I. \& NASCIMENTO, M. das G. Trajetórias de professores: a pesquisa com histórias de vida. In: MENDONÇA, A. W.(Org). História e Educação: dialogando com as fontes.Rio de Janeiro: Forma \& Ação, 2010.

LÉLIS, I.A polissemia do magistério:entre mitos e histórias. Rio de Janeiro, 1996. Tese de doutorado. Departamento de Educação. PUC- Rio.

MARCHI, R.C. Walter Benjamin e a infância: apontamentos impressionistas sobre sua(s) narrativa(s) a partir de narrativas diversas. Revista Educação,v.34, n.2, p.221- 229, 2011.

MEDEIROS, F. E. As dimensões lúdicas da experiência de infância: entre os registros de brinquedos e brincadeiras da obra de Franklin Cascaes e a memória de infância de velhos moradores da Ilha de Santa Catarina e de velhos açorianos de "Além Mar".Tese de doutorado em Educação Física, Santa Catarina: Universidade Federal de Santa Catarina, 2011.

MEIRELES, C. M. Criança, meu amor. Rio de Janeiro: Nova Fronteira, 1977.

NEVES, V. F. A. História coletiva e construções subjetivas: uma trama de narrativas em uma creche comunitária. Educação em Revista, v.29, n.1, p.225246, 2013. 
OLIVEIRA, D. P. S. (Coord.). História de Tanguá.Rio de Janeiro: Centro Universitário Augusto Motta, 2000.

OLIVEIRA, P. de S.Vidas Compartilhadas: Cultura e relações intergeracionais na vida cotidiana.São Paulo: Cortez, 2011.

OLIVEIRA, R. L. S. Fotografia e Memórias: a criação de passados.Dissertação de Mestrado em Educação, Universidade Estadual do Sudoeste da Bahia-UESB, 2011.

PARK, M. B.Memória em movimento na formação dos professores. Campinas: Mercado das Letras, 2000.

PENA, A. C. "Para explicar o presente tem que estudar a história do passado":narrativas de profissionais de escolas comunitárias de educação infantil da Baixada Fluminense. Tese de Doutorado em Educação, Rio de Janeiro, PUC Rio, 2015.

PORTELLI, A. O que faz a história oral diferente. Projeto História:Revista do Programa de Estudos pós-graduados em História e do Departamento de História, n. 14, São Paulo: PUC-SP, 1997.

QUEIROZ, M. I. P.de. Relatos orais: do "indizível” ao "dizível”. In: SIMON, O. de M. V. (Org.). Experimentos com histórias de vida (Itália-Brasil). São Paulo: Vértice/Editora Revista dos Tribunais, 1988.

SANTOS, S. V. S. Walter Benjamin e a experiência infantil: contribuições para a educação infantil. Educação \&Sociedade, v. 26, n.2, p. 223-239, 2015.

SIMAN, L. M. C. Memórias sobre a história de uma cidade: a história como labirinto. Educação em Revista,2008, v. 24, n.47, p. 241-270, 2008.

TAVARES, M. T. G.. Os "Pequenos" e a cidade: o papel da escola na construção do direito a cidade. Contexto e Educação,v.3, n.78, p.69-92, 2007.

TOSATTO, C.; PORTILHO, E. M. L. A criança e a infância sob o olhar da professora de educação infantil. Educação em Revista,v.30, n.3, p.153-172, 2014. 